Historic, archived document

Do not assume content reflects current scientific knowledge, policies, or practices. 

Ad 6 TP

(C) United States

Agriculture

Soil

Conservation

Service

SCS-TP-157

EPA-

$6007-79-134$

Plant Materials for Use on Surface-Mined Lands in Arid and Semiarid Regions

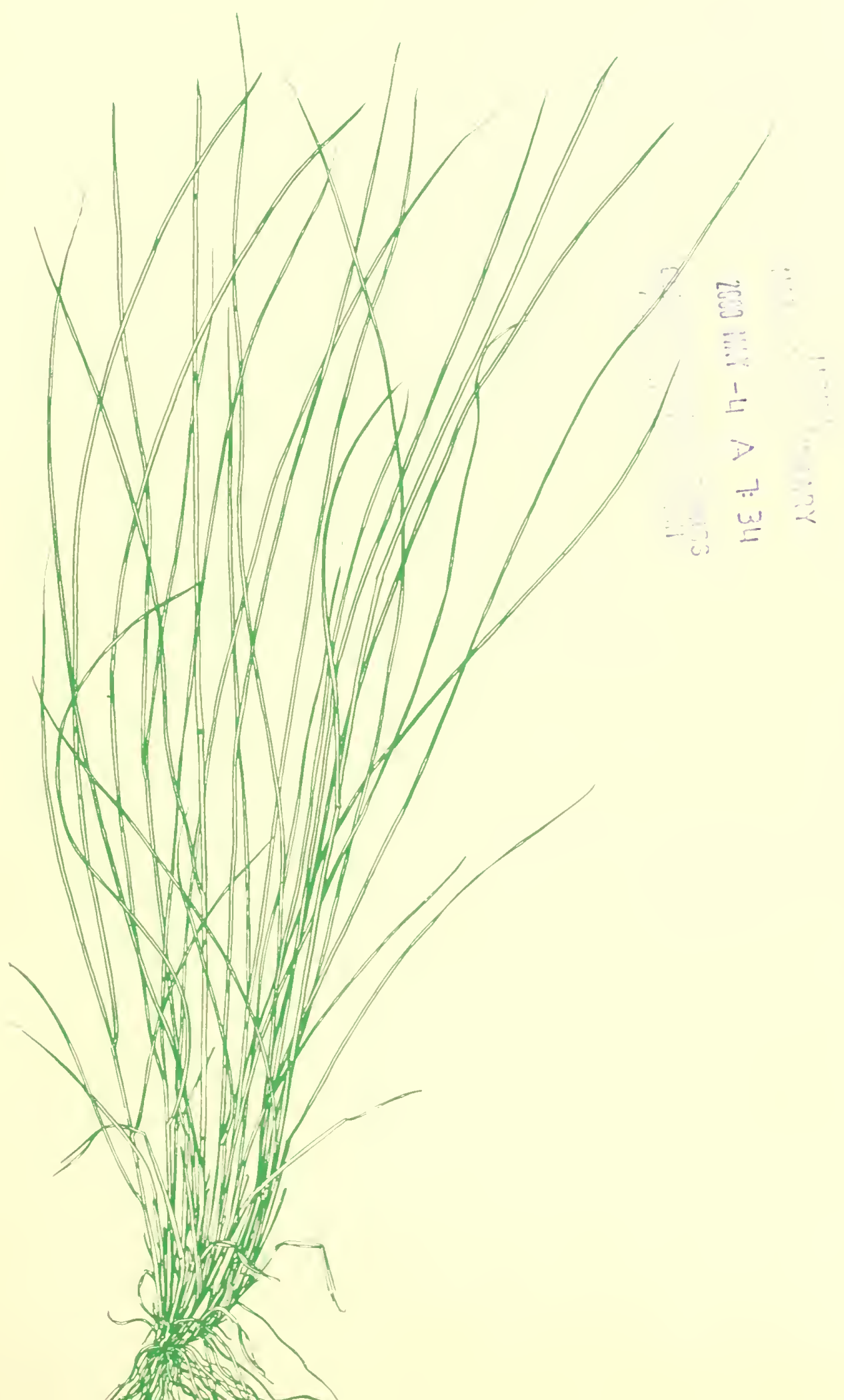





\section{Plant Materials for Use on Surface-Mined Lands in Arid and Semiarid Regions}

Ashley A. Thornburg

plant materials specialist

Soil Conservation Service 
Partial funding for accelerating studies and publication of this report was provided by the Interagency Energy/Environment Research and Development Program under Federal Research Interagency Agreement IAG D-5-E765. This program was inaugurated in fiscal year 1975 and is planned and coordinated by the Environmental Protection Agency (EPA) Research projects supported by the program range from the analysis of health and environmental effects of energy systems to the development of environmental control technologies. The EPA coordinator is Ronald Hill, Resource Extraction and Handling Division, Industrial Environmental Research Laboratory, Cincinnati, Ohio 45268.
Partial funding has also been provided by the Forest Service Surface Environment and Mining Program (SEAM) under Section 601. Economy Act (31 U.S.C. 686). Cooperative agreements enabled the plant materials centers in Bridger, Mont., Meeker, Colo., Bismarck, N. Dak., and Los Lunas, N. Mex., to accelerate work in developing plant materials for research and demonstrations, assisting commercial seed growers and nurserymen to produce new materials, recording information on establishment methods and plant performance, and producing this publication. 


\section{Contents}



Planning and land use alternatives $\ldots \ldots \ldots \ldots \ldots \ldots \ldots \ldots \ldots \ldots$

Treatment of mined lands ............................ 2

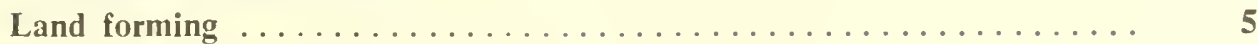

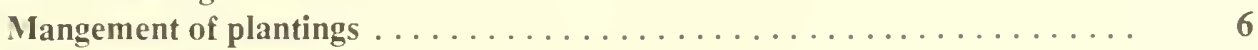



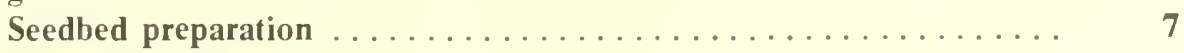

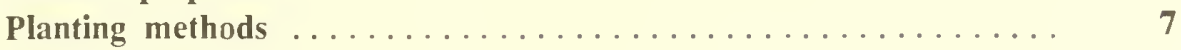

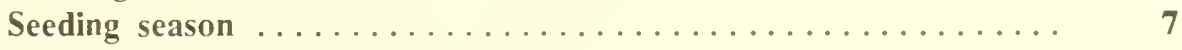

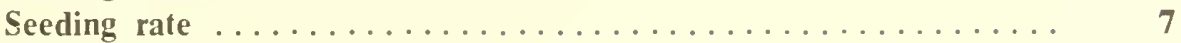

Fertilizers $\ldots \ldots \ldots \ldots \ldots \ldots \ldots \ldots \ldots \ldots \ldots \ldots \ldots \ldots . \ldots \ldots$

Mulches ............................ 8

Temporary cover crops $\ldots \ldots \ldots \ldots \ldots \ldots \ldots \ldots \ldots \ldots \ldots$



Irrigation for establishment $\ldots \ldots \ldots \ldots \ldots \ldots \ldots \ldots \ldots$



Single species and mixtures $\ldots \ldots \ldots \ldots \ldots \ldots \ldots \ldots \ldots . \ldots \ldots$

Adapted ecotypes and cultivars $\ldots \ldots \ldots \ldots \ldots \ldots \ldots \ldots \ldots \ldots . \ldots \ldots$

Introduced and native species $\ldots \ldots \ldots \ldots \ldots \ldots \ldots \ldots \ldots \ldots$

Plant growth regions $\ldots \ldots \ldots \ldots \ldots \ldots \ldots \ldots \ldots \ldots \ldots \ldots \ldots$

Major land resource areas for plant growth regions ............. 12

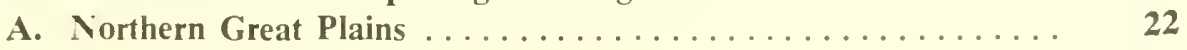

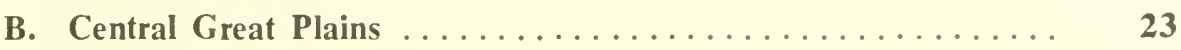



D. Northern Rocky Mountains .................. 24

E. Central Rocky Mountains ................... 25

F. Southern Rocky Mountains .................. 25

G. Palouse Prairie, Columbia Basin and Plateau ............ 26

H. Snake River Plain and Eastern Idaho .............. 26

I. Great Basin Intermontane .................... 27

J. Northern and Central Intermountain Desertic Basins ........ 28

K. Southern Plateaus $\ldots \ldots \ldots \ldots \ldots \ldots \ldots \ldots \ldots \ldots \ldots \ldots . \ldots \ldots$

L. Cascade-Sierra Nevada ...................... 29

M. California Valleys and Foothills ................. 29

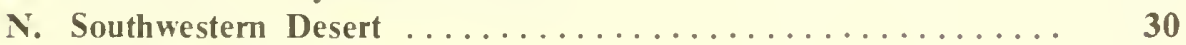

Selected plant materials $\ldots \ldots \ldots \ldots \ldots \ldots \ldots \ldots \ldots \ldots \ldots \ldots \ldots . \ldots \ldots$





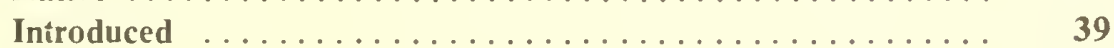

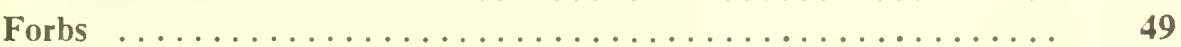



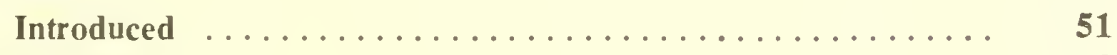



Native trees $\ldots \ldots \ldots \ldots \ldots \ldots \ldots \ldots \ldots \ldots \ldots \ldots \ldots \ldots \ldots$

Native shrubs ........................ 57

Introduced trees and shrubs $\ldots \ldots \ldots \ldots \ldots \ldots \ldots \ldots \ldots \ldots$

Common and scientific names of plants $\ldots \ldots \ldots \ldots \ldots \ldots \ldots \ldots . \ldots 6$





Tables $\ldots \ldots \ldots \ldots \ldots \ldots \ldots \ldots \ldots \ldots \ldots \ldots \ldots \ldots \ldots \ldots \ldots$ 



\section{Introduction}

Lands that have been mined and drastically disturbed can seldom be returned to their original condition. According to Box (1978), drastically disturbed areas are those in which the native vegetation and animal communities are removed and most of the topsoil is lost, altered, or buried. Box says, "The process of rebuilding a plant community must start from a new growth medium, usually a mixture of subsoil, rocks, and soils.... The natural process often must be helped by artificially introducing new plant communities or by altering the conditions under which new plant communities may develop."

For more than 40 years the Soil Conservation Service (SCS) has been sy'stematically testing conservation plant materials in the western United States. Many of these plants are now used to rehabilitate, as far as possible, those lands already disturbed by mining. Current mining practices generally include plans for rehabilitation before the land is actually mined. This provides an opportunity to consider alternatives for future use and emphasizes the importance of selecting the plant species and cultivars needed for each land use according to the site and climatic conditions. Such practices are especially important for arid and semiarid environments.

Both the Environmental Protection Agency and the Forest Service Surface Environmental and Mining Program (SEAM) made funds available to SCS for finding and testing plant materials. With such assistance it was then possible to expand the assemblies of conservation plants for the selection of new materials, the development of cultural and production techniques, and methods for establishing these materials on field sites. These cooperative efforts also helped to expand the testing to include a large number of trees and shrubs and to continue testing grasses and forbs.

This publication describes the characteristics, areas of adaptation, and performance of plant materials for mine spoils. General guidance is given for species selection, use, establishment, availability. and management techniques. Specific information can be obtained for each site from local SCS offices, the Extension Service, Forest Service, and other agencies. Many of the plants described as named cultivars have been released by SCS cooperatively with state agricultural experiment stations or other agencies. Many varieties are in commercial production and are available for use. Other plants are named that have shown promise or are believed to have potential for use on surface-mined lands in arid and semiarid areas.

The information is largely from the work of the SCS plant materials centers and from the evaluation of materials on farms and ranches in soil and water conservation districts.

The scientific names in the text are in the U.S. Department of Agriculture SCS (1971) National List of Scientific Plant Names. Synonymy is provided in parentheses where recent

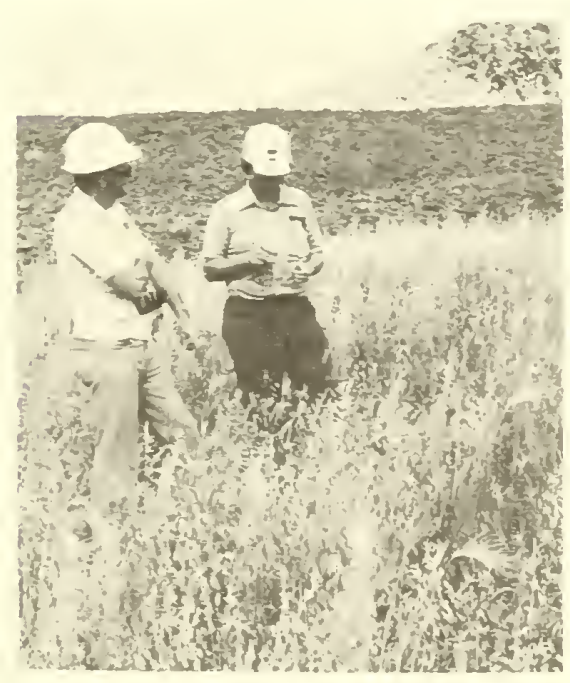

Figure 1. Wheal grows on reclaimed surface-mined land in North Dakola. Grain crops are used as a lemporary protective cover while spoil malerials sellle. use indicates that changes are being considered. The authority for the common names and spelling is the Soil Conservation Service National Soils Handbook Notice 30, dated March 20, 1978.

\section{Planning and land use alternatives}

Mined lands can be reclaimed for almost any land use, but for a particular site the alternatives may be restricted by the adapted planting materials available or by some other factor. Use of the land should be within the capabilities of the disturbed soil materials and the climatic limitations and should insure long-term production or benefits. The use must be compatible with the planned operations of the farm, ranch, or other unit; however, state laws should be investigated for possible restrictions. Wildlife habitat and recreation opportunities need to be considered, especially on public lands. If potential wildlife values are high, biologists can help to develop the reclamation plan.

An important inventory, especially in the arid and semiarid West. is the range site survey. Shiflet (1973) points out that each range site is the product of environmental factors that interact to produce a distinctive plant community. The range site survey can help determine potential land uses as well as the selection of species.

Before mining begins it is essential to establish the potential land uses determined by inventories of soils, topography, overburden materials, ground-water aquifers, plants, wildlife, and present land use (fig. 1). Mined land is reclaimed through the manipulation of mine wastes, overburden, and soil materials so that toxic materials are buried between the rooting zone and the water table, overburden materials having the best properties for supporting plant growth are placed in the root zone, 
slopes are stable and compatible with the planned use, and soil materials are returned to the surface.

Generally, the more surface soil material returned to the surface the greater the productive capacity, although in some places parts of the overburden are superior to the surface materials. Decisions must be made carefully because the productive capacity of the manmade soil is established at this time. It may be difficult to restore some mined lands to premined levels of total production or diversity of species within a limited time. In other areas there will be opportunities to return the land to a greater productive capacity than existed before mining began.

Where available material is limited, the soil's productive capacity may be inadequate for complete land reclamation but may support enough vegetation to control wind and water erosion. In other places, soil materials may be unavailable or so limited that adequate vegetation cannot be established and maintained to prevent wind and water erosion. These sites require critical area treatment with continuing fertilization, replanting, and higher levels of management to maintain air and water quality and acceptable esthetic quality.

\section{Treatment of mined lands}

The problems in reclaiming mined lands are similar even though the mined commodities differ. The kind of commodity dictates mining methods, and alternative land uses are more limited for some commodities than for others. The general principles for selecting plants and establishing vegetation should be used.

Private, state, and federal ownership of surface and mineral rights exist in all possible combinations. Decisions on final land use and reclamation procedures vary with state legislation. The owner of the land may or may not have a voice in determining land use after mining; this decision may rest with the mine operator or the state. Legislative requirements may differ for different commodities; there may be no legislative requirements for any commodity or only requirements for selected minerals.

Most of the abandoned mined lands in the West were mined many years ago when equipment was smaller; therefore the areas with the least overburden were mined. The spoils are not as large as those madc with modern equipment and the volume of material to be moved is not as great.

Even within the same region conditions vary considerably for the same commodity (fig. 2). Almost invariably the surface materials were covered in mining and are not available for use in reclamation. The spoil piles may have different configurations because of the mining



Figure 2. Abandoned mine spoils in Montana. method but all need some landforming to have satisfactory topographic and surface conditions for establishing vegetation (fig. 3 ).

"Reclamation of Drastically Disturbed Lands," the American Society of Agronomy (1978) publication, contains detailed information on the problems associated with reclamation of many commodities.

\section{Bentonite mines}

Several thousand acres of land have been disturbed by bentonite mining in the West, the majority being in Montana, Wyoming, and northwestern South Dakota. The major reclamation problem is with abandoned mined lands. The overburden is shallow, usually from 20 to 30 feet (6 to $9 \mathrm{~m})$. There are no deep pits or huge spoils. These deposits are usually associated with shales of high $\mathrm{pH}$ and the surface 




Figure 3. Spoils of a mined area are graded to a landscape suitable for establishing vegetation.

soil materials are of ten thin. In some areas the natural vegetation cover is sparse. Surface soil materials were not salvaged, the overburden was mixed, and the overburden materials were not returned to the pits. The material under the bentonite is an unfractured shale incapable of supporting vegetation.

Bentonite occurs in scattered lenses, and usually more land is disturbed by haul roads than by pits and spoils. The scattered pits are in open range and, in the proper locations, provide an opportunity to develop livestock water. To accomplish satisfactory reclamation, livestock must be excluded through a grazing management system or by fencing individual pits.

Tresler (1974) provides considerable information on reclaiming bentonite and other mines in the several mining provinces of Wyoming. Modern methods salvage the soil materials and return the overburden to the pit where it is covered with soil materials.

\section{Coal mines}

Each coal mine differs in thickness of the seam, depth and characteristics. Coal seams in the West are often very thick and there is not enough overburden material to return the area to its original contour after the coal is mined. Provisions are needed for returning the topography to a contour that will drain surface runoff safely. The coal seams may have 150 or more feet $(46 \mathrm{~m})$ of overburden and the final cut leaves a vertical highwall. State and federal requirements may stipulate that this be eliminated or the slope reduced. In those mines examined to date, most of the spoils have a $\mathrm{pH}$ of 7.5 to 9.0. Overburdens may have highly sodic horizons, and mining plans that provide for placing these materials in the lower part of the profile are needed.

In the West, mining of large areas may be planned for several thousand acres over a period of 35 to 40 years. Reclamation must be carried on continuously so that units can be used and then fit into the operation of the entire farm or ranch after the mining is completed. Opportunities may be created to develop water for livestock or wildlife or for recreation uses.

\section{Copper mines}

Copper mines are huge open pits that may be more than a mile wide $(1.6 \mathrm{~km})$ and thousands of feet deep.
They generally do not contribute sediment to drainageways. Overburdens are composed of many materials, and it may be possible to cover the spoils with materials capable of supporting plant growth. Reclamation of the pit is generally impractical.

\section{Gypsum mines}

Gypsum mines have not disturbed a significant amount of land. Reclamation depends on the overburden material and the amount of available surface materials. Few species of plants are capable of growing in gypsum-bearing materials, and these materials must be covered with suitable soil materials.

\section{Oil shale mines}

Oil shales underlie about 25,000 $\mathrm{mi}^{2}\left(64,750 \mathrm{~km}^{2}\right)$ of southwestern Wyoming, western Colorado, and northeastern Utah. Potentially hundreds of thousands of acres could be disturbed. Several agencies and universities are conducting research on reclamation, and SCS plant materials centers are selecting plants capable of growing on these disturbed areas.

Sedgley (1974) reports that land rehabilitation problems fall into the two broad categories of disturbed areas and waste disposal piles. Present technology is generally adequate for successful revegetation of the disturbed areas by using native plants or introduced plant communities.

Sedgley states that the most difficult revegetation effort is the stabilization of waste disposal areas. Spent shale materials vary somewhat, depending on the system of retorting, but are generally a black carbonized material high in soluble salts and devoid of basic plant nutrients. Demonstration plots indicate that the spent shale material supports plants if it is leveled, nuulched, fertilized, leached, and irrigated. Studies are being made of soil materials 
applied over spent shale and of surface materials mixed with the spent shale.

Grant Davis (1978) cites considerable information on oil shale occurrence and the problems associated with its development. Reclamation research was begun early in the development of oil shale, and Davis believes that the technology for rehabilitation of spent shale and related disturbances will be available long before other problems associated with oil shale development are solved.

\section{Phosphate mines}

Phosphate mines in the West are located in mountainous areas with favorable moisture but a short growing season. The major reclamation problem is that their location makes it difficult or impractical to place the spoil on the stable slopes. The Forest Service has done considerable research on revegetation of phosphate mines in the West. Farmer and Blue (1978) discuss reclamation of phosphate mines and the adapted plant species in the intermountain area of the West.

\section{Placer mines}

The U.S. Department of Interior (1967) reported that about 200,000 acres $(81,000$ ha) have been disturbed by gold-dredge tailings, mostly in Alaska and California and some in Montana, Idaho, Oregon, and Colorado. Placer mining for gold has been seldom used for many years, and the environmental problems of disturbing streams would make such an operation difficult.

The spoils are on stream bottoms and are composed of coarse fragments generally classified as rocks and boulders. Surface materials are not available to cover these areas sufficiently to revegetate them, and almost any reclamation procedure would produce large amounts of sediment. Few of the old placer mine spoils produce sediment, in- dicating that the least amount of environmental degradation would occur if these spoils were left undisturbed. The spoils are usually in a regular pattern and often located near abandoned mine towns where they may be most useful as tourist and historical attractions.

\section{Sand and gravel pits}

These pits account for approximately 26 percent of the total area disturbed by surface mining in the United States. Many pits are reclaimed because of their concentration in urban areas where land values are high. In most areas such reclamation is not required by law.

The extent of site grading of sand and gravel pits varies with the intended use and with the mining process used. Overburdens are usually not thick and surface materials are available for reclamation if salvage plans are made before mining begins. The overburden is often coarse material with low waterholding capacity. A layer of clay or other fine-textured material may be necessary before adding the cover of surface material. Recreation developments and housing are often possible.

\section{Uranium mines}

Uranium mines are deep pits, and reclamation opportunities are confined largely to the spoils. Because many geologic formations are included in the overburden of deep pits, there are opportunities to place suitable plant growth materials near the surface. Tresler (1974) reports that a peculiarity of the Gas Hills uranium area of Wyoming is that most of the materials below the surface-oxidized zone are strongly acid with $\mathrm{pH}$ values as low as 2.5 . Old spoils are barren of vegetation after being exposed for as long as 10 years. These spoils must be covered with soil materials.

Waste materials from uranium and phosphate mines have been used for various types of buildings and as fill materials. Some of these materials are radioactive.

Caution: Waste materials should be handled carefully.

\section{Mine tailings}

Mine tailings are of every description and range of characteristics. Each area is unique and must be analyzed before plant species are selected. Wind erosion may be a severe problem and must be treated before permanent vegetation can be established. Slopes of the tailings piles may be composed of finetextured to coarse materials or rocks and must be shaped to a stable grade before plantings are made. It may be necessary to reduce acidity before any vegetation can be established. Donovan, et al. (1976) discuss the vegetative stabilization of mineral waste heaps.

\section{Mercury (cinnabar) mines}

Mercury is surface mined. The mines are small and the mercury is extracted from the ore in furnaces near the mining operation. Mercury is very toxic, and the mined area is dammed to prevent any runoff to surrounding areas.

\section{Quarries}

Quarries from which limestone, slate, granite, or similar materials are fractured and removed have limited reclamation possibilities. The floor of a quarry can be revegetated if enough soil materials are available. Water impoundments may be possible in some areas. Safety measures should be considered.

\section{Molybdenum mines and high elevation disturbances}

Molybdenum is the primary mineral mined in Colorado. Reclamation is unique because the mines are located at elevations above 11,500 feet $(3,507 \mathrm{~m})$. Brown, et al. (1978) point out that tundra climates are among the most rigorous in the world and consist of many 
Vegetation rarely

satisfactory

Seedbed preparation limited

Wheeled implements can operate

Better species performance

Figure 4. Slope limitations for establishing vegetation.

diverse microclimates. Cook, et al. (1974) found that topsoil is scarce and must be inventoried and carefully stockpiled. Both Cook and Brown list a number of plants that are suitable at high elevations.

Among these are hard fescue, creeping and meadow foxtails, smooth brome, tufted hairgrass, and shrubby cinquefoil. Few plants are available commercially. SCS has found that plantings of most species are successful only where local ecotypes are used.

\section{Land forming}

The first consideration of land forming is that the slopes are sufficiently stable and satisfactory to establish vegetation to reduce erosion and sedimentation. The topography should be sloped to a configuration suitable for the planned use after mining, be esthetically pleasing, and blend with the surrounding undisturbed terrain. The surface should be satisfactory for applying topsoil or other material suitable for plant growth. This may require roughening or chiseling to permit better fusion and stability of the surface materials. Power, et al. (1978) discuss the properties of mine spoils in the northern Great Plains. They point out that restoring the productivity of mined lands requires the creation of a plant-growing medium that effectively conserves the limited water resources.

\section{Slopes}

Vegetation is rarely satisfactory on slopes steeper than 2:1 (50 percent). Slopes should be this steep only where the natural terrain or some other limitation prohibits further reduction. Plant performance is generally adequate for conservation protection on $3: 1$ (33 percent) slopes but is superior on slopes that are less steep. Slopes 3:1 and flatter can be worked with wheeled equipment and seedbed preparation and planting can be controlled. Slopes on sands should not exceed 4:1 (25 percent) (fig. 4).

Slope stability is a function of soil particle size, shape, and distribution; slope length; climate; and moisture. Length of slopes should be reduced by berms placed at appropriate intervals consistent with the erodibility of the material and the planned use.

\section{Salvage and replacement of surface materials}

A satisfactory vegetative cover may depend on the use of surface soils. In some places some layer of the overburden profile may contain materials satisfactory for plant growth but high priority should be given to salvaging the surface materials (fig. 5). State and other legislation may require the use of surface materials or other materials proved satisfactory for plant growth and may specify the amount. Legislation varies by state and usually by the commodity being mined. The soil materials should be applied uniformly over the surface to a minimum depth of 6 to 8 inches ( 15 to $20 \mathrm{~cm}$ ). Federal legislation requires specific reclamation procedures for areas designated as prime farmlands.

\section{Highwalls}

In most types of surface mining a highwall is left with the final cut. The final disposition of the highwall is treated in some legislation. Highwalls may consis! of nonerodible materials and may be an esthetic asset, but they are often a safety hazard to people and animals. If a highwall is to be left untreated, provisions should be made for safety.

\section{Water areas}

If water areas are to be a part of the reclaimed area, they should be planned for a specific purpose before the land is disturbed. Such areas do not justify reducing the amount of reclamation required. They may be the only source of livestock water or may be planned for recreation or wildlife. Legislation may require a permit for water areas and for diverted drainage patterns.

\section{Toxic materials}

Toxic materials in the overburden or waste should be buried where they will not contribute to the pollution of surface or underground waters. They should be buried at depths below the rooting zone to avoid possible incorporation in to the food chain. Legislation may specify minimum amounts of cover, depending on the type of toxic material. 


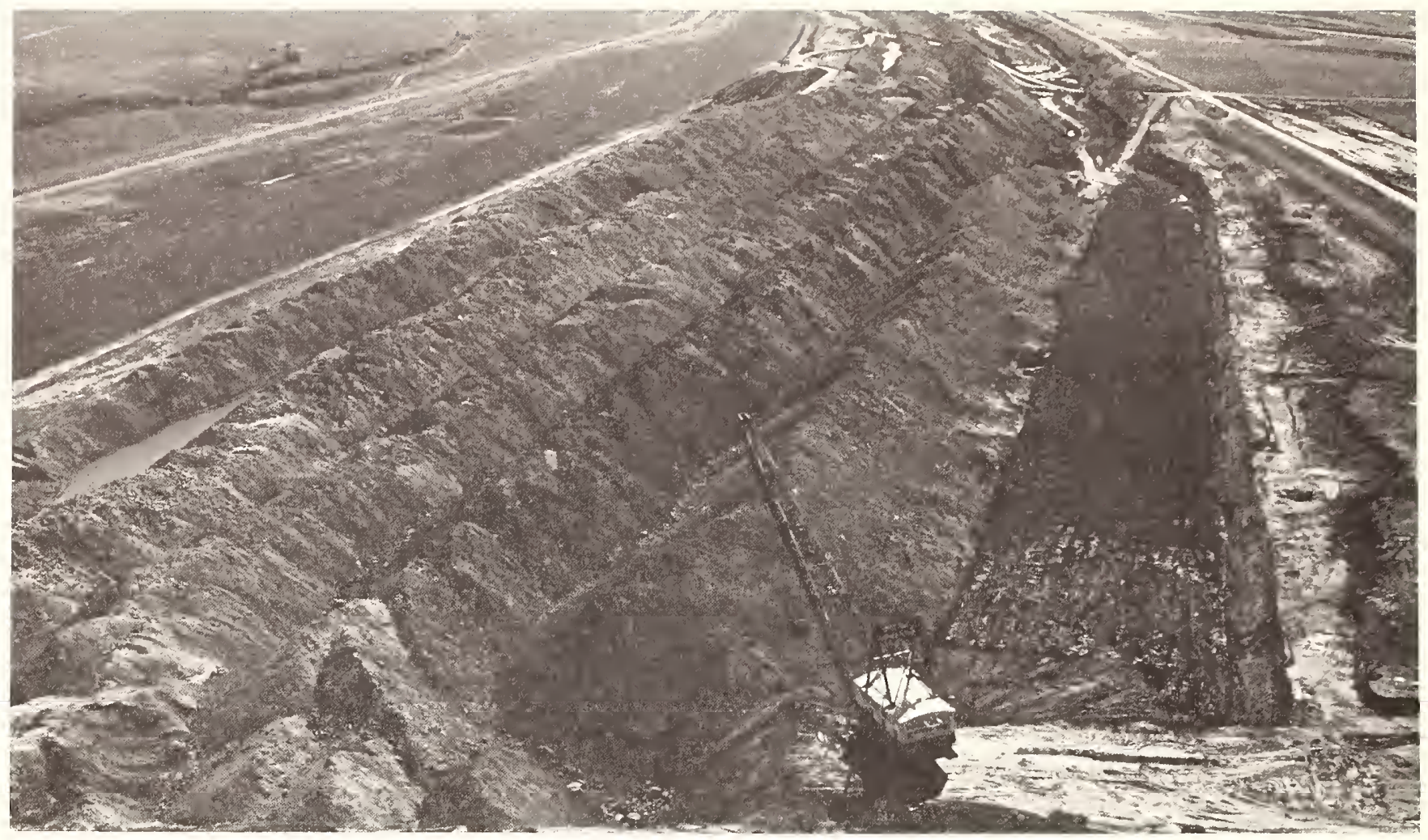

Figure 5. The five "windrows" on the left of this stripmine on the Northern Great Plains are overburden removed by dragline to reveal the coal seam on the right. Overburden and topsoil will be replaced after coal has been extracted. (SEA 0878X941-20)

\section{Management of plantings}

Some level of management is needed to establish and maintain plantings in any climate. In arid and semiarid areas a higher level of management must be planned if adequate stands are to be established and maintained.

A stand may require from 2 to 5 years to become established in arid and semiarid areas. Often plantings that were thought to be a failure at the end of the seeding year develop into excellent stands. Plantings should not be destroyed until they have been thoroughly examined by someone who can identify the seeds and seedlings. Seeds may germinate 1 or 2 years after seeding if moisture was not available earlier.

Shrubby species generally need a longer period of protection and more time to become established than do grasses. Livestock must be excluded until the stand is established and has matured, and fences may be needed where wildlife populations are heavy.

Seeded areas, during and after establishment, are usually more attractive to livestock and wildlife than the surrounding undisturbed areas. A grazing management system is needed to maintain adequate cover and production and to prevent loss of stands (fig. 6). It may be necessary to fence revegetated areas and treat them as separate units within the entire farm or ranch.

Fire is generally detrimental to plants and should be used as a management tool only with expert assistance. Most desirable shrubby species will be destroyed if not protected. Fires on steep slopes generate such intense heat that most plants are killed.
The use of fertilizers varies depending on the plant species, the site conditions, and the desired productivity and cover. Most mine sites require fertilization for several years after establishment.

Lands managed as habitat for game birds and other wildlife should be mowed, burned, cropped, or grazed only under a management plan designed to improve conditions for wildlife. Herbicides should be used only if they are needed to control primary noxious weeds. If native plant species are protected from overgrazing, fire, and herbicides, they generally provide adequate cover for upland game. Plantings need to be large enough to provicie enough cover, food, or escape for a specific wildlife species. Biologists should be consulted when wildlife aspects of reclamation are being planned. 


\section{Revegetation}

The techniques for revegetating areas are not significantly different from those that have been successfully used for seeding rangelands and pastures and planting critical areas. Cook, et al. (1974) provide excellent guidelines for revegetating surface-mined areas, using several natural vegetation types of the West. SCS technical guides for each conservation district include specific details on choice of species and applicable techniques.

\section{Seedbed preparation}

Before the seedbed is prepared, any concentrated flow of offsite water should be diverted from the area by using appropriate measures to prevent erosion and to comply with state requirements. The area to be planted should be reasonably smooth and free of rills and gullies to provide the best possible soil conditions for seeding. The area should be free of perennial plants and, as far as possible, free of annual weed seeds. The seedbed should be firm so that the seed is not planted too deep or in loose soil. Generally the seedbed is improved by having a noncompetitive mulch cover or stubble to reduce surface drying, soil crusting, and erosion during establishment.

\section{Planting methods}

Seed is planted either by drilling or broadcasting. Drilling is preferred where topography and surface conditions permit the operation of equipment.

Drilling with a double disk drill equipped with depth bands and press wheels is best for establishing grass, forb, and legume seed (fig. 7). Drills should have agitators to prevent the seed from lodging in the seedbox. Small grass, forb, and legume seed should be seeded at a maximum depth of $1 / 2$ inch $(1.3 \mathrm{~cm})$. Large grass seed can be planted as much as $3 / 4$ inch $(1.9 \mathrm{~cm})$ deep except on

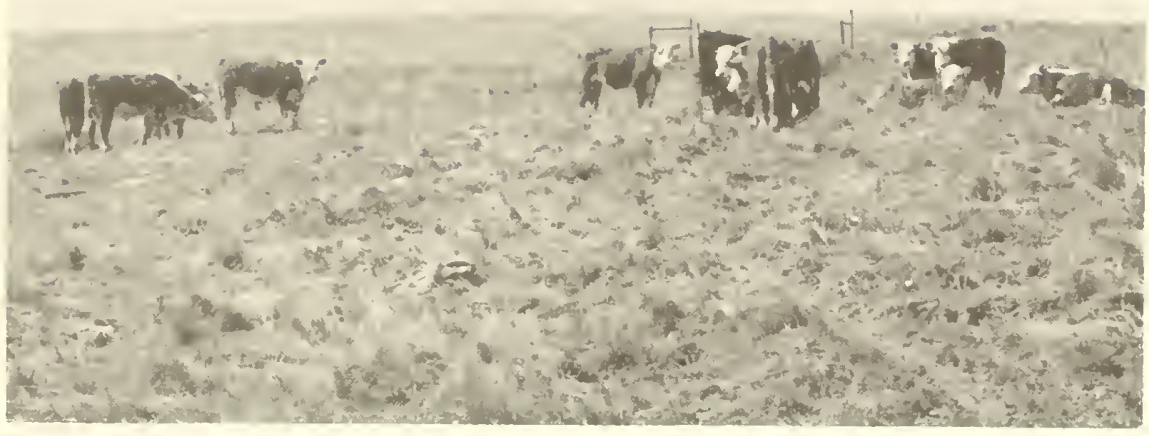

Figure 6. Cattle graze on reclaimed land.

sand, where 1 inch $(2.5 \mathrm{~cm})$ or deeper may be recommended for some species.

Broadcasting scatters the seed directly on the soil surface. This can be done with hydroseeders that apply the seed with water or other liquid carrier, with air blast seeders, or by hand seeding. The seed must be covered by harrowing, raking, or some other method if it is to become established. If mulches are used in conjunction with broadcast seeding, the mulch should be applied after the seed is broadcast and covered with soil.

Transplanting bare root or containerized plants is the standard procedure for establishing woody materials. Establishing grasses with sod, plugs, or container-grown materials may be the most satisfactory solution on some sites.

Transplanting indigenous trees and shrubs from the premined zone into the reclamation area has been successful in the northern Great Plains and other areas. Chris Cull (1978) reports that transplanting is labor intensive and relatively expensive but is justified by the survival rates. This technique uses a resource that is normally lost in the mining operation.

\section{Seeding season}

Local SCS offices can recommend the best dates for seeding. In general, the best time is just before the season receiving the most depend- able precipitation begins. Irrigation provides an opportunity to adjust planting dates, depending on other climatic and site factors and species requirements.

Areas where most of the precipitation occurs during spring and summer should be seeded early in spring, preferably before the middle of April, though warm-season grasses can be seeded until the middle of June in the northern Great Plains.

Dormant seedings of cool-season species for spring germination can be made late in fall or early in winter when temperatures are too cool for germination. Seedings should not be made when the soil is frozen or snow covered.

\section{Seeding rate}

Seeding rates are determined by seed size, seeding method, and seedling vigor and are adjusted according to the severity of the site conditions. In general, grass seed drilling rates on favorable sites should be a minimum of 20 pure live seed per square foot $\left(0.093 \mathrm{~m}^{2}\right)$ and increased on unfavorable sites. The experience of SCS and others has been that broadcast seeding generally requires about twice as much seed as drilling.

Seeding rates are generally expressed in pounds of pure live seed per acre. Pure live seed is the product of the percentage of purity of a lot of seed multiplied by the per- 


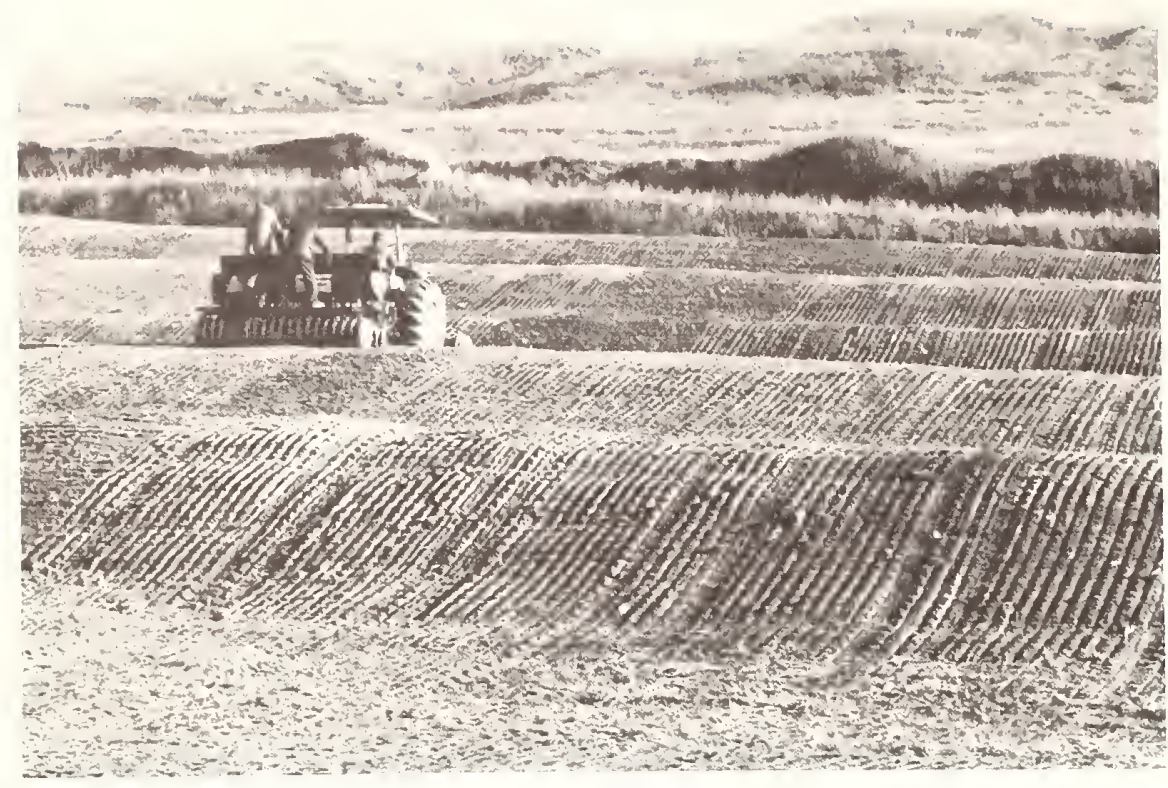

Figure 7. Grasses and forbs are planted with a drill equipped with depth bands and packer wheels.

centage of germination and divided by 100 . Pure live seed is necessary for many of the native grasses because both the purity and the germination may vary widely among seed lots. Seed should be free of noxious weeds and meet the quality requirements of state laws.

\section{Fertilizers}

Fertilizer applications on mined lands should be determined by soil tests. Phosphorus and potassium alone or in combination have shown little benefit to seedling establishment. Nitrogen often increases weed growth and competition for moisture. Sites without topsoil, where fertility is low and where weeds are not a problem, have benefited from fertilizers. Fertilizers are needed on most mined sites after the vegetation becomes established (fig. 8).

\section{Mulches}

Mulches conserve moisture by reducing evaporation, erosion, and temperature. They reduce crusting and provide mechanical stability until seedlings are established (fig.
9). Mulches are often necessary and are generally beneficial in the arid and semiarid areas, especially on south- and west-facing slopes and on saline or alkaline areas. In areas where precipitation is between 18 and 25 inches (46 and $64 \mathrm{~cm}$ ), mulches are generally not needed except on steep s!opes. In arid areas where precipitation is between 8 and 10 inches ( 20 and $25 \mathrm{~cm}$ ), seeding success varies even if mulches are used (Cook, et al. 1974). Where annual precipitation is less than 8 inches $(20 \mathrm{~cm})$, seedings may fail unless precipitation and other environmental conditions are above normal during the establishment period or unless supplemental irrigation is used.

Desert areas are often difficult to revegetate without pits or basins and mulches, and then supplemental irrigation may be needed.

\section{Mulch should consist of clean} cereal grain straw, grass hay, longfiber wood cellulose, or commercial materials developed for this purpose. The mulch must be anchored by an anchoring tool equipped with notched disks, emulsified asphalt, soil-anchored mulch, or netting materials.

Wood fiber applied at $3 / 4$ to 1 ton per acre (1.7 to 2.2 metric tons/ha) on stable slopes has given good results except in areas where there is frost heaving or excessive surface water flow. If wood fiber is applied at rates less than $1 / 2$ ton per acre ( 1 metric ton/ha) or on unstable slopes, little benefit is obtained (Cook, et al. 1974).

Straw at $1 \frac{1 / 2}{2}$ to 2 tons per acre ( 3.4 to 4.5 metric tons/ha) bound with about 300 gallons per acre $(2,800 \mathrm{~L} / \mathrm{ha})$ of asphalt emulsion gives beneficial results. In areas subject to strong winds, the mulch may blow if tied down with asphalt. If possible, it is best to use a mulchanchoring machine equipped with notched disks. Grain straw is often contaminated with grain and weed seeds that compete with the newly planted grass seedlings.

Grass hay is less brittle than grain straw and is generally superior mulching material. It should be examined to make sure that it does not contain excessive viable weed seed or seed of undesirable plants. About $1 \frac{1 / 2}{2}$ to 2 tons per acre (3.4 to 4.5 metric tons/ha) is recommended. Grass hay must be anchored.

\section{Temporary cover crops}

The stubble of temporary cover crops of sudangrass, grain or forage sorghums, and cereal grains provide! protection and a firm seedbed for the grasses. The stubble should be kept 8 to 18 inches ( 20 to $46 \mathrm{~cm}$ ) high. Winter grains seeded late in spring or spring grains seeded early in summer fail to produce a grain crop and offer good protection for seedings. Winter-grain seeding should be done late enough in spring or summer for the mulch crop to be winter killed before it can produce seed. 


\section{Weed control}

Annual weeds and grasses compete with grass seedings and cause poor stands or failures. Postemergence herbicides may be needed during the year of establishment and the following year, though mowing is often preferable. Weeds may not be as great a problem if mines are isolated from sources of weed seeds and the soil materials are sufficiently free of seeds.

CAUTION: Pesticides may be hazardous to health or the environment. Use them only as directed on the container label.

\section{Irrigation for establishment}

On some mine sites enough water is available to establish vegetation. Aldon (1978) states that supplemental water is needed on areas receiving less than 8 inches $(20 \mathrm{~cm})$ of precipitation. He suggests that drip irrigation can be used if the water is in short supply and high plant density is not critical. The water should be analyzed for quality because it may be suitable for establishment but not for long-term use. SCS irrigation guides should be referred to for use and design requirements.

\section{Selection of species}

The selection of the proper species for plantings should be determined by the climate and soils and the use and management planned. Good (1953) pointed out that plant distribution is controlled primarily by climate and secondarily by edaphic factors and that plant functions are limited by definite ranges of tolerance for particular factors. The limiting factors are accentuated in dry climates where moisture and its seasonal availability are most critical. The waterholding capacity of the soil affects the composition of the natural vegetation and the selection of species. This is more pronounced in semiarid areas than in arid areas. In ex- tremely arid areas other soil and site characteristics and such factors as slope, exposure, toxic conditions, and biotic relationships become critical. Information on adaptation to precipitation, soils, and plant growth regions is included in table 1 for approximately 200 species described in the section "Selected plant materials."

Important considerations are the seasonal availability of moisture and the total amount available. The experience of SCS has been that some species, such as basin wildrye, that are adapted to the winter-wet and summer-dry climate of the Great Basin area of the West are not well adapted to the summer maximum precipitation pattern of the Great Plains. Little bluestem and several other species of the plains are not adapted to the summer droughts of the Great Basin though the temperature patterns are similar.

Species must be tolerant to the restrictions imposed by the soil. The major soil limitations for vegetation are droughtiness, fine or coarse textures, presence of a claypan, wetness, salinity or alkalinity, acidity, shallow depth, and toxicity or severe nutrient imbalance. Slope, stoniness, and the amount and quality of surface materials available for reclamation are also important within the climatic range of adaptation of each species.

The objective in most reclamation plantings in arid and semiarid regions is to minimize erosion and maximize the value of the site for other land uses. Generally, the soils are not the same as before the disturbance occurred and it may be necessary to select species that are lower in the successional stage. These species are usually more easily established and can initiate primary succession.

The characteristics of many species are well known, and by selecting species that fit within the planned land use and tolerate the limitations



Figure 8. Lush growth on overburden results from fertilizer treatments. In the background is control plot without fertilization. (SEA 878X934-23)

imposed by the site and climate, a satisfactory solution can be found for all but the most extreme conditions. At times selection may be governed by the availability of planting materials, which may necessitate choosing an alternative land use. Some of the species characteristics that need to be considered are tolerance to salinity or acidity, tolerance to grazing, fertility and moisture requirements including tolerance to drought or wetness, regrowth ability, season of growth, palatability to different classes of livestock and wildlife, productivity and quality of the forage depending on the planned use, longevity of species on different sites, ease of establishment, tolerance to high temperatures, winterhardiness, adaptation to soil textures and depths, compatibility in mixtures, and conservation value.

\section{Single species and mixtures}

Whether a single species or a mixture is selected depends on several factors, including planned use, visual 
compatibility with the surrounding vegetation, and visual appropriateness for the intended land use.

The species selected must be compatible in the mixture. The limitations for successful growth on reclaimed areas are usually different from those on the adjacent undisturbed area, where a complex community of a number of species may be growing together in what appears to be a stable population. Species interactions are complex, and species that may be compatible on one site may not be as compatible on a different site.

Esthetically pleasing materials may be a single species or a mixture. The public and at times the law require diversity. Selection for appearance is important because public approval is based largely on appearance rather than on the effectiveness for the planned use. Some persons prefer a site that is planted to a single species and maintained in a manicured condition or is uniform in height, color, and texture. Others prefer a natural arrangement that may or may not consist of native species.

Even after the species have been selected, the proportionate amounts are not easily determined. The best guide to success of either a single species or a mixture is the successful experience of the past 35 to 40 years in seeding range mixtures and planting critical areas.

\section{Adapted ecotypes and cultivars}

It is essential to understand the inherent variability within individual populations of a species in order to select the proper planting materials for long-term reclamation. An ecotype is a population of plants that has become genetically differentiated in response to selection pressures exerted by site conditions and spatial or other breeding isolation mechanisms. Each ecotype reflects the conditions of elevation, precipitation, temperature, growing season, and the soil and site conditions of its origin.

Species may have restricted ranges of distribution or may grow naturally over large areas. A widely distributed species may occupy many sites or be restricted to specific soil types or moisture conditions within its range. The species is almost invariably made up of numerous ecotypes, of ten with narrow ranges of adaptation. Though an ecotype may be grown over a wide area, satisfactory performance may be restricted and the maintenance of a self-perpetuating stand limited to a small geographic area or to specific sites.

The experience of SCS, as reported by Cooper (1957) and observed in the evaluations of many assemblies at plant materials centers, has been that an ecotype can perform satisfactorily if it is moved about 250 to 300 miles (400 to 480 $\mathrm{km})$ north or 100 to 150 miles (160 to $240 \mathrm{~km}$ ) south of the point of origin to areas of comparable soils and moisture. Movement east or west may be greater or less, depending on changes in elevation and precipitation. Some species, especially cool-season plants, have wider ranges of ecological amplitude and perform satisfactorily over wider ranges of conditions. Materials moved farther from the point of origin cannot compete with local ecotypes of the same or other species. Plants moved northward grow during more of the available growing season than local ecotypes and are generally leafier. They perform well until moved too far north to produce a seed or fruit crop or until they are injured by winter conditions. Plants moved southward do not use the available growing season, are usually less vigorous, and are more susceptible to disease. Some species are sensitive to day length, which may limit north-south movement.

Selection of the proper ecotype or cultivar of an improved plant is as important as species selection. The term cultivar is used throughout the text to refer to a named and released assemblage of plants. It is an international term derived from a culti-



Figure 9. Mulching materials help seedlings become established. 
vated variety and is used to avoid confusion with the botanical variety, varietas, which is a category below that of species. The available cultivars of native plants are mainly selected ecotypes that exhibit superior performance in defined areas. The areas of adaptation follow the principles for those of native ecotypes though the range of adaptation is often greater.

\section{Introduced and native species}

The use of introduced species for reclamation of disturbed areas is a controversial subject in many parts of the West. Legislation may specify that mined areas be returned to a diverse cover of native plants. This has resulted in the use of unadapted ecotypes of native species instead of adapted introduced species. Such a practice limits the uses that can be made of an area. There is some justification for the opposition to introduced species because many are not as long lived in arid and semiarid areas as the adapted native species. Long-lived, self-perpetuating stands are important because of the hazards associated with reestablishment on some sites. However, the condemnation of all introduced species cannot be justified. Some introduced species, such as crested wheatgrass and pubescent wheatgrass, have performed well for decades in semiarid environments. Tall wheatgrass is more easily established and has been superior to any native species on many saline sites.

Though the primary consideration of reclamation in arid and semiarid areas is cover to reduce erosion and sedimentation, agricultural production should also be considered. Power, et al. (1978) believe there is no technology at present to restore economically the mixed native prairie of the northern Great Plains in less than 30 to 40 years. These authors found that introduced species can be established and are generally more productive but also require more skillful management to achieve and maintain this productivity. If reclaimed areas are to be irrigated, many introduced species have greater production potential. There are also opportunities to develop dryland pastures of introduced species in semiarid areas where enough moisture is available.

The commonly used introduced species generally have a greater range of adaptation to soils and climate, but they also require a high level of management and energy inputs to provide long-term protection.

Both adapted introduced plants and native plants are useful for reclaiming mined areas in arid and semiarid regions. Species selection should be determined by the planned use and the specific site conditions, not on whether a plant is introduced or native.

\section{Plant growth regions}

This publication treats the United States west of the 100th meridian, excluding the humid Pacific Northwest. The Rocky Mountains and other western mountains, though they are classified as subhumid. are included because the foothills and valleys are mainly arid or semiarid.

For the purposes of this publication the arid and semiarid areas of the West have been divided into 14 general plant growth regions. Such regions are artificial designations of geographical areas over which the environmental complex produced by climate, topography, and soils is sufficiently uniform to permit the development of characteristic ecological associations. The limits of the range of a number of species of plants and animals may coincide along the borders of the growth regions, especially where there is a barrier to distribution or a more or less abrupt change in environmental conditions. However, the range of a naturally occurring species or the area of adaptation of an introduced plant usually does not stop abruptly at the borders of the regions. As Dice (1943) points out, a species characteristic of one province may occur far beyond the area of its greatest abundance or area of dominance.

Of the 156 major land resource areas in the continental United States defined by SCS (Austin 1965), 73 are considered here. These areas (MLRA's) consist of geographically associated land resource units several thousand acres in extent that are characterized by particular patterns of soil, climate, water resources, and land use.

The plant growth regions have been adjusted to the boundaries of the major land resource areas. MLRA numbers following the plant growth region names in the text refer to corresponding areas on the MLRA maps. Brief descriptions of the climate, topography, vegetation, and wildlife in each region follow. Plant growth regions are similar to those described by Mulford (1938) and by Thornburg and Fuchs (1978).

Several systems have been developed by climatologists to differentiate the extremes and combinations of factors used to describe broad climatic areas. This publication uses the classification developed by Thornthwaite (1931) for describing the various combinations of humidity, evapotranspiration, temperature, and seasonal adequacy of precipitation.

The work of Kuchler (1964) was a major source of data on the potential natural vegetation of the plant growth regions. The major references for wildlife values of plants were Martin, et al. (1951), Graham (1941), and SCS biologists. 


\section{Major land resource areas for plant growth regions}

A. Northern Great Plains

52 - Brown Glaciated Plain

53A - Northern Dark Brown Glaciated Plains

53B - Central Dark Brown Glaciated Plains

53C — Southern Dark Brown Glaciated Plains

54 - Rolling Soft Shale Plain

58A - Northern Rolling High Plains (Northern Part)

58B - Northern Rolling High Plains (Southern Part)

58C - Northern Rolling High Plains (Northeastern Part)

58D - Northern Rolling High Plains (Eastern Part)

60 - Pierre Shale Plains and Badlands

61 - Black Hills Footslopes

62 - Black Hills

63 - Rolling Pierre Shale Plains

64 - Mixed Sandy and Silty Tableland

65 - Nebraska Sand Hills

66 - Dakota-Nebraska Eroded Tableland

67 - Central High Plains

B. Central Great Plains

67 - Central High Plains

69 - Upper Arkansas Valley Rolling Plains

70 - Pecos-Canadian Plains and Valleys

71 - Central Nebraska Loess Hills

72 - Central High Tableland

73 - Rolling Plains and Breaks

77 - Southern High Plains

78 - Central Rolling Red Plains

79 - Great Bend Sand Plains

C. Southern Plains

81 - Edwards Plateau

82 - Texas Central Basin

83A - Eastern Rio Grande Plain

83B - Western Rio Grande Plain

83C - Central Rio Grande Plain

83D - Lower Rio Grande Valley

D. Northern Rocky Mountains

43 - Northern Rocky Mountains

44 - Northern Rocky Mountain Valleys

45 - Alpine Meadows and Rockland

46 - Northern Rocky Mountain Foothills

E. Central Rocky Mountains

47 - Wasatch and Uinta Mountains

48A - Southern Rocky Mountains

48B - Southern Rocky Mountain Parks

49 - Southern Rocky Mountain Foothills

51 - High Intermountain Valleys
F. Southern Rocky Mountains

39 - Arizona and New Mexico Mountains

G. Palouse Prairie, Columbia Basin and Plateau

7 - Columbia Basin

8 - Columbia Plateau

9 - Palouse and Nez Perce Prairies

H. Snake River Plain and Eastern Idaho

10 - Upper Snake River Lava Plains and Hills

11 - Snake River Plains

12 - Lost River Valleys and Mountains

13 - Eastern Idaho Plateaus

I. Great Basin Intermontane

21 - Klamath and Shasta Valleys and Basins

23 - Malheur High Plateau

24 - Humboldt Area

25 - Owyhee High Plateau

26 - Carson Basin and Mountains

27 - Fallon-Lovelock Area

28A - Great Salt Lake Area

28B - Central Nevada Basin and Range

29 - Southern Nevada Basin and Range

35 - Colorado and Green River Plateaus

37 - San Juan River Valley Mesas and Plateaus

J. Northern and Central Intermountain Desertic Basins

32 - Northern Intermountain Desertic Basins

33 - Semiarid Rocky Mountains

34 - Central Desertic Basins, Mountains and Plateaus

K. Southern Plateaus

36 - New Mexico and Arizona Plateaus and Mesas

41 - Southeastern Arizona Basin and Range

42 - Southern Desertic Basins, Plains and Mountains

L. Cascade-Sierra Nevada

$$
\begin{array}{r}
6 \text { - Cascade Mountains (Eastern Slope) } \\
22 \text { - Sierra Nevada }
\end{array}
$$

M. California Valleys and Foothills

17 - Sacramento and San Joaquin Valleys

18 - Sierra Nevada Foothills

\section{N. Southwestern Desert}

30 - Sonoran Basin and Range

31 - Imperial Valley

40 - Central Arizona Basin and Range 


\section{PLANT GROWTH REGIONS OF THE ARID AND SEMIARID AREAS OF THE WESTERN UNITED STATES}

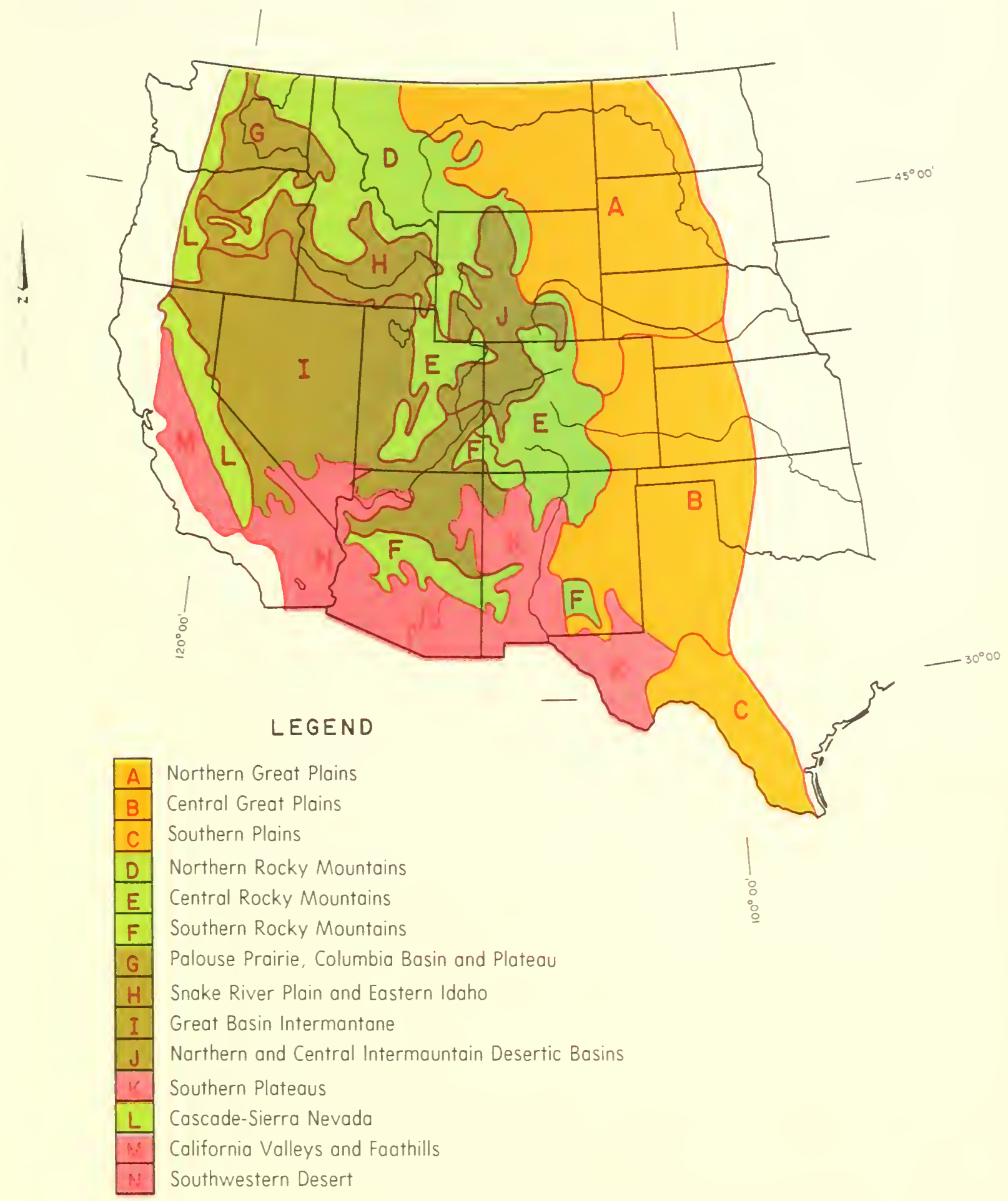




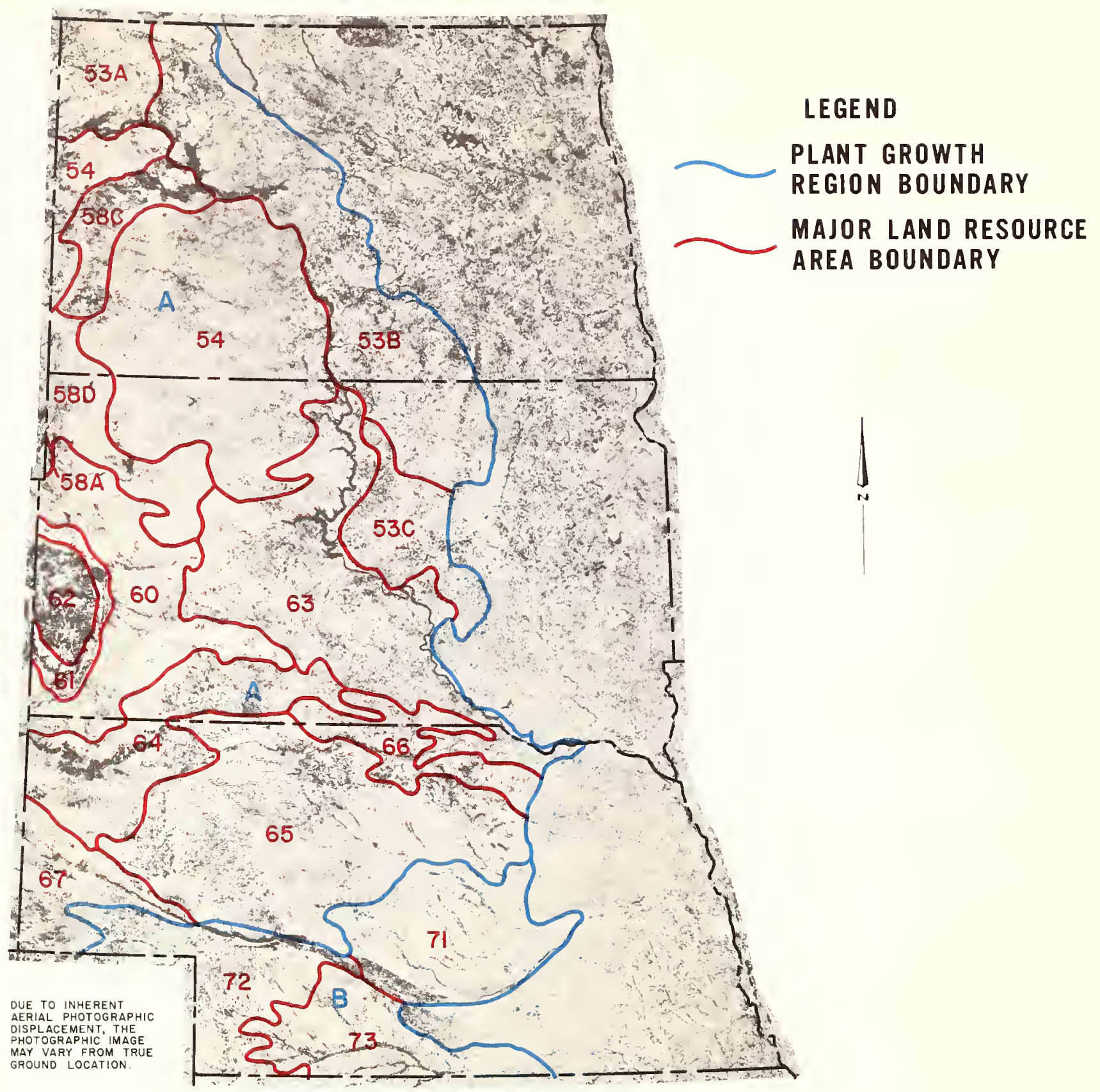

\section{MAJOR LAND RESOURCE AREAS NORTH DAKOTA, SOUTH DAKOTA, AND NEBRASKA}

SOURCE
BANO 5 CONTERMINOUS

USA. MAP COMPILEO

FROM MOSAICEO IMAGERY

FROM LANOSAT, (NASA

TECHNOLOGY SATELLITE,

FROM FIELD TECHNICIANS.

ALBERS EOUAL AREA PROJECTION 




\section{MAJOR LAND RESOURCE AREAS CALIFORNIA AND NEVADA}

SOURCE

BANO 5 CONTERMINOUS

US.A. MAP COMPILEO
FROM MOSAICEO IMAGERY

FROM LANOSAT. (NASA'S

EARTH RESOURCES

I / 6,000,000

ERTS - I) AND INFORMATIO

ALBERS EQUAL AREA PROJECTION 




SOURCE

BAND 5 CONTERMINOUS

U.S. A. MAP COMPILED

FROM MOSAICED IMAGERY
FROM LANDSAT, (NASA'S

EARTH RESOURCES
TECHNOLOGY SATELLITE,

TECHNOLOGY SATELLITE,
ERTS-I) AND INFORMATION

ALBERS EQUAL AREA PROJECTION

$1 / 6,000,000$ 


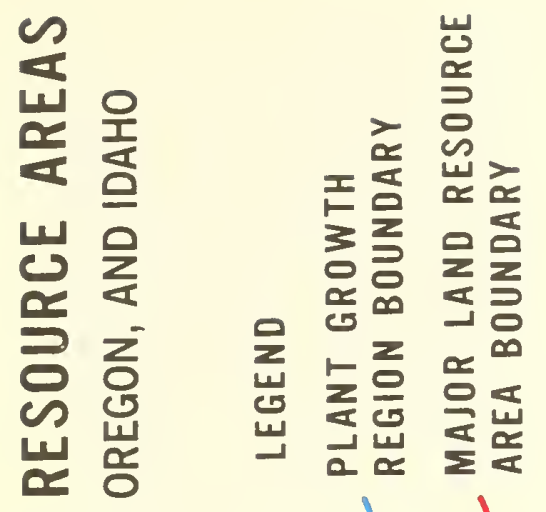

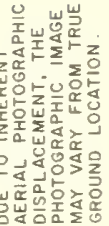

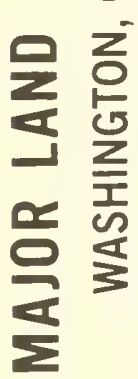


山字

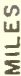

trater $\}$,

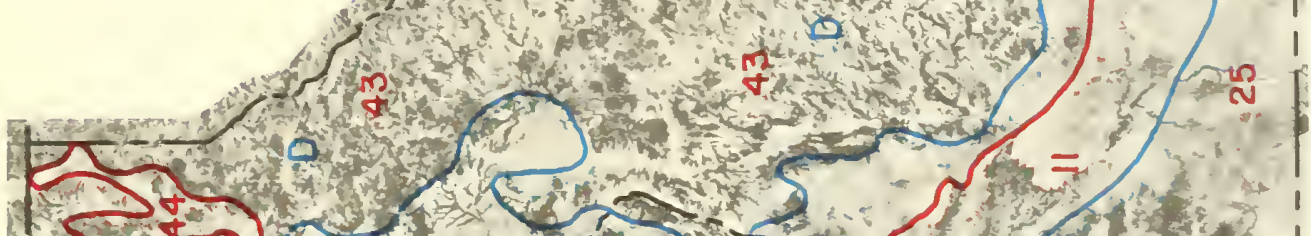

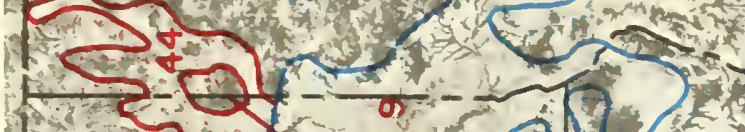

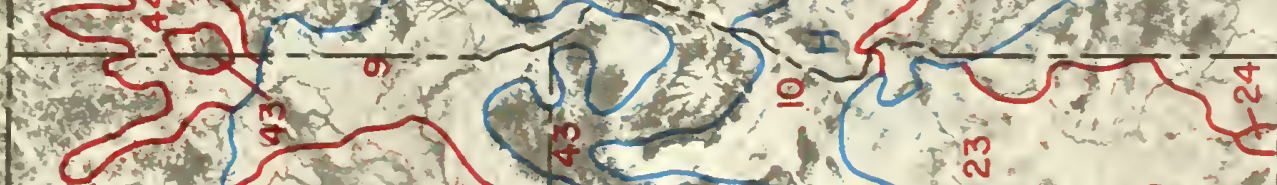

10 content

$\prod_{t \rightarrow 2}^{2}-x^{2}$
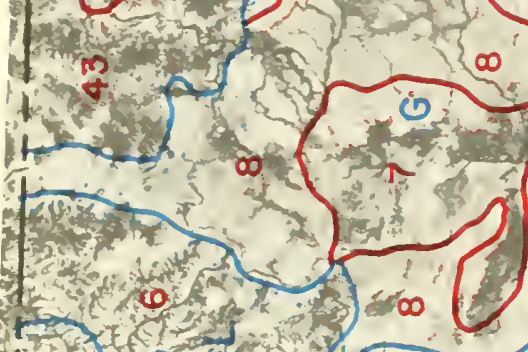

trotiction

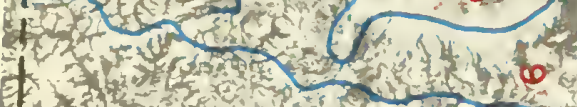



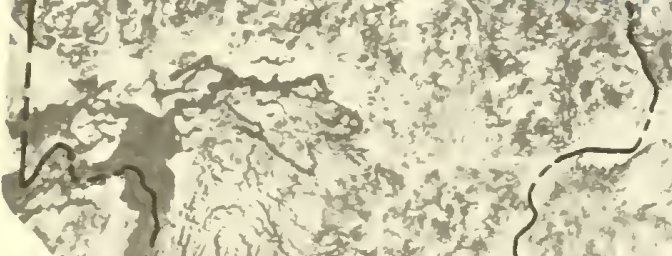

Thlo
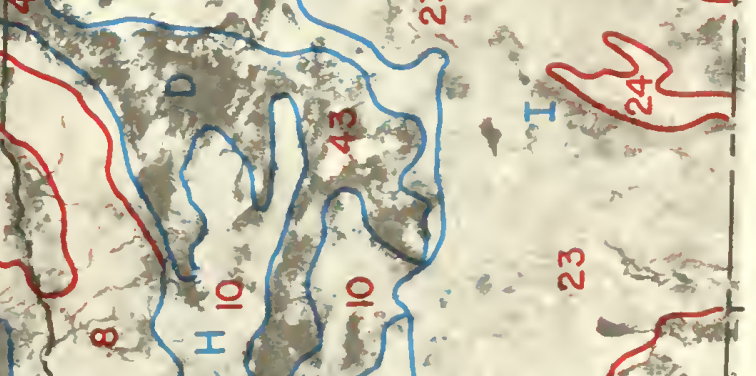

U.

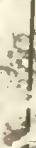









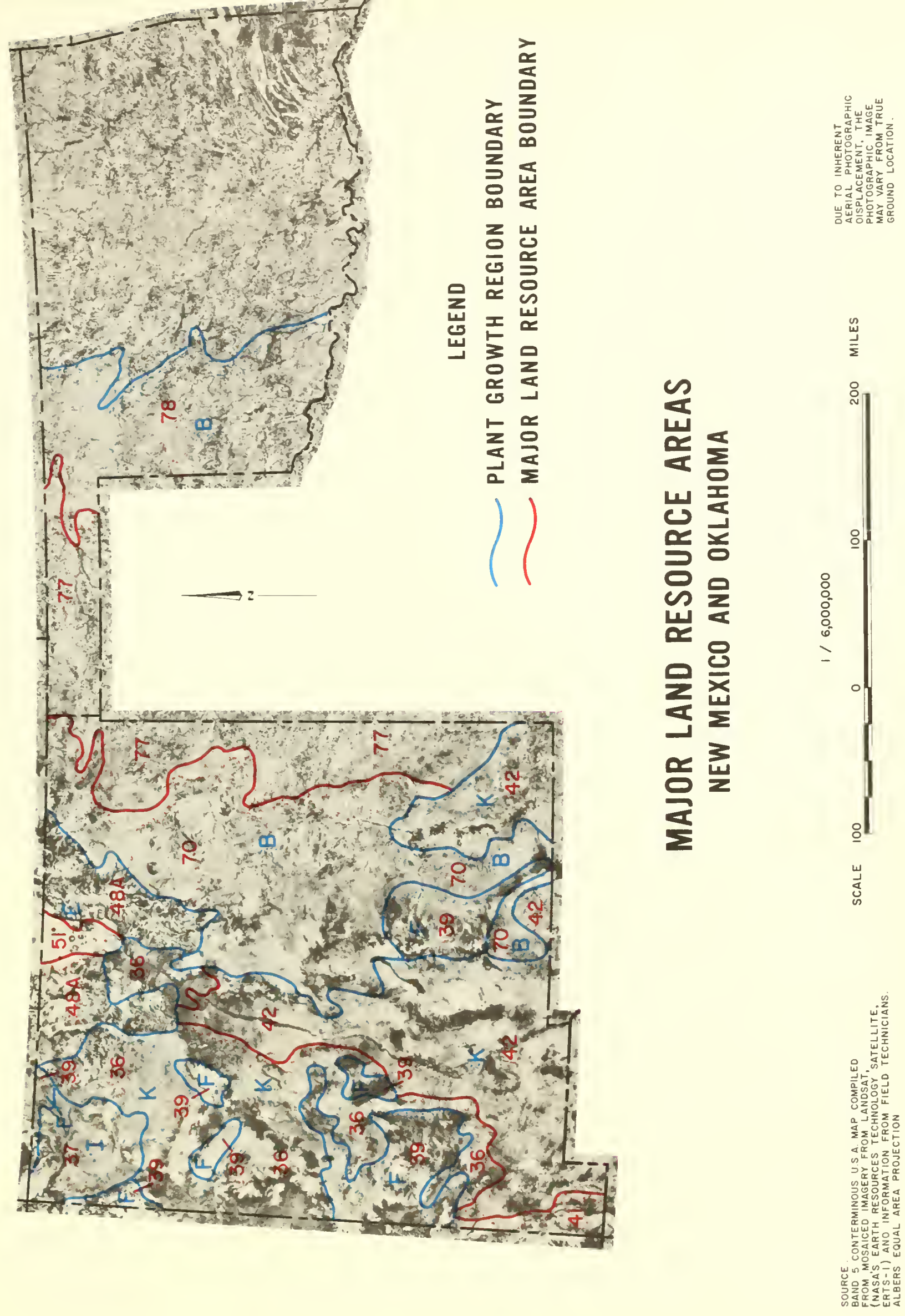




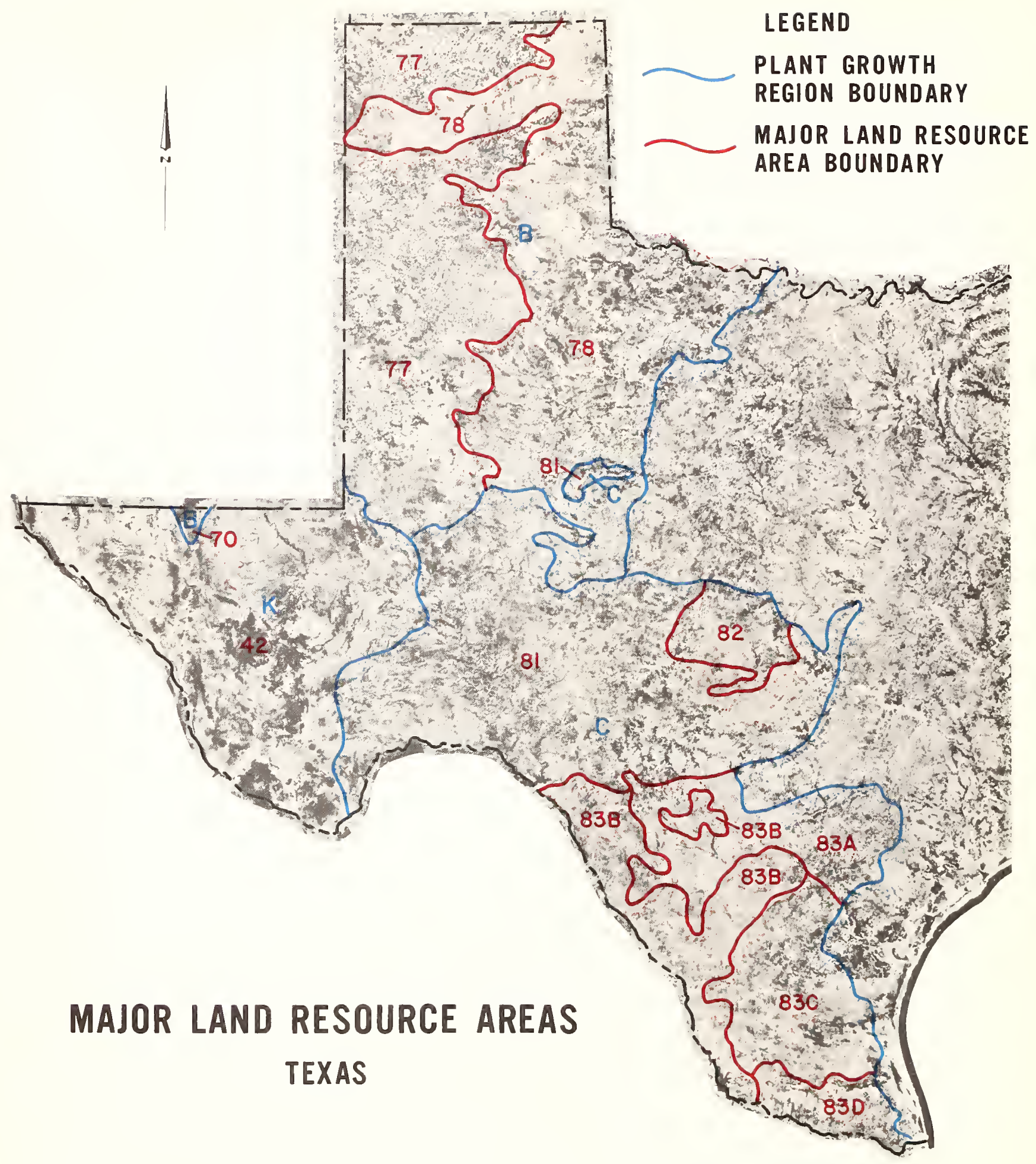

DUE TO INHERENT DISPLACEMENT, THE PHOTOGRAPHIC IMAGE MAY VARY FROM TRUE
GROUND LOCATION.

SOURCE

GAND 5 CONTERMINOUS

U.S.A MAP COMPILED FROM MAPACED MAE'S

EARTH RESOURCES

TECHNOLOGY SATELLITE,

ERTS - 1) AND INFORMATION

ALBERS EQUAL AREA PROJECTION

\begin{tabular}{llll} 
SCALE & 100 & 0 & 200 \\
\hline
\end{tabular} 
LEGEND

PLANT GROWTH REGION BOUNDARY

MAJOR LAND RESOURCE AREA BOUNDARY

DUE TO INHERENT AERIAL PHOTOGRAPHIC DISPLACEMENT, THE PHOTOGRAPHIC IMAGE MAY VARY FROM TRU
GROUND LOCATION
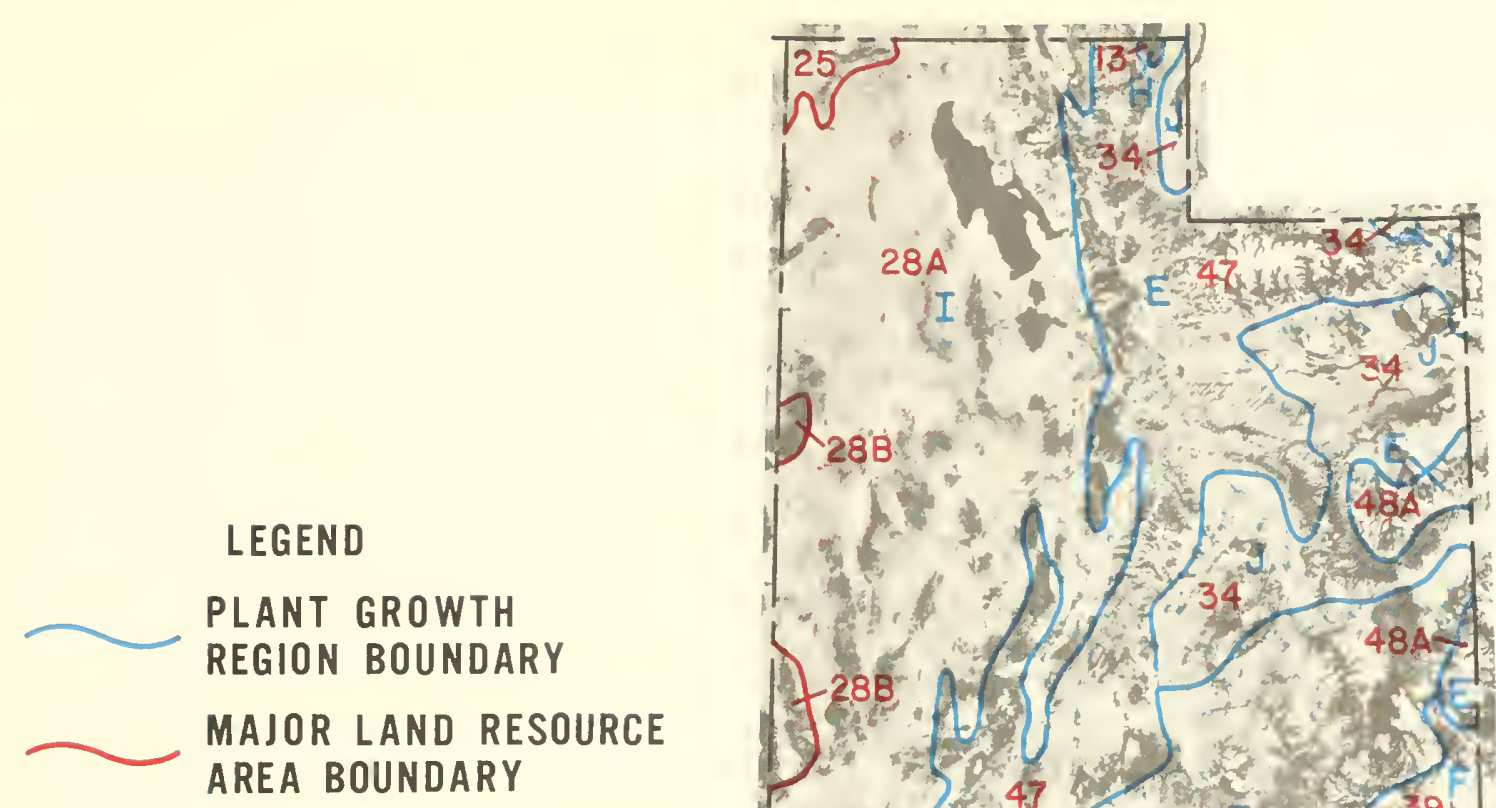


\section{A. Northern Great Plains}

Western Dakotas, western Nebraska, northeastern Colorado, Montana, and Wyoming west to Rocky Mountain foothills. 247,000 $\mathrm{mi}^{2}\left(640,000 \mathrm{~km}^{2}\right)$

\section{MLRA's}

Brown Glaciated Plain (52)

Dark Brown Glaciated Plains (53 A, B, C)

Rolling Soft Shale Plain (54)

Northern Rolling High Plains (58 A, B, C, D)

Pierre Shale Plains and Badlands (60)

Black Hills Footslopes (61)

Black Hills (62)

Rolling Pierre Shale Plains (63)

Mixed Sandy and Silty Tableland (64)

Nebraska Sand Hills (65)

Dakota-Nebraska Eroded Tableland (66)

Central High Plains (67)

Climate. The climate is mainly continental. The mean annual precipitation is 12 to 16 inches ( 30 to $40 \mathrm{~cm}$ ). The precipitation is maximum in late spring to early autumn and fluctuates widely from year to year (fig. 10). The mean annual temperature is 40 to $50^{\circ} \mathrm{F}\left(4\right.$ to $\left.10^{\circ} \mathrm{C}\right)$. The frost-free period is 100 to 140 days and as much as 160 days in the southern part.

Elevation and topography. The elevation is 2,000 to 5,000 feet $(610$ to $1,525 \mathrm{~m}$ ). Topography consists of gently rolling glaciated plains in the north to dissected rolling shale plains over most of the area. The Black Hills, rising to more than 7,000 feet $(2,135 \mathrm{~m})$, and the unique Nebraska sand hills, composed of stabilized sand dunes, are included in this plant growth region.

Vegetation. The primary vegetation is short to medium, mainly coolseason grasses. There are some lowdensity forested areas in which ponderosa pine is dominant. This

Northern Great Plains Region

Bowman, North Dakota

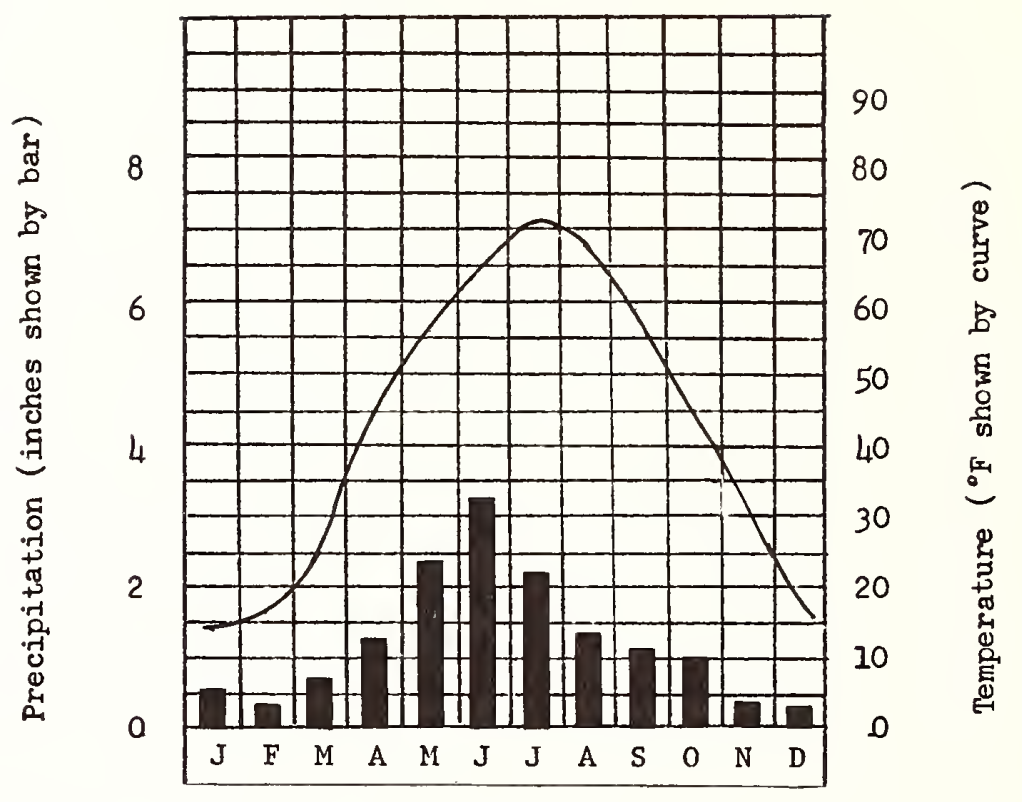

$\begin{array}{lccl}\text { Longitude } & 103^{\circ} 23^{\prime} \mathrm{W} & \text { Mean annual precipitation } & 14.7 \text { inches } \\ \text { Latitude } & 46^{\circ} 11^{\prime} \mathrm{N} & \text { Mean annual temperature } & 42^{\circ} \mathrm{F} \\ \text { Elevation } & 2,500 \text { feet } & \text { Frost-free period } & 130 \text { days } \\ \begin{array}{l}\text { Figure 10. Climatic graph of a station representative of the Northern Great Plains } \\ \text { Region. }\end{array}\end{array}$

region's good cover of grasses includes western wheatgrass, blue grama, and needleandthread. Other plants, depending on the site, are bluebunch wheatgrass, prairie junegrass, and Sandberg bluegrass. Little bluestem is locally prominent on some sites. Throughout much of the area, big sagebrush, fringed sagewort, and blue grama increase with heavy grazing. Where precipitation exceeds 12 inches $(30 \mathrm{~cm})$ per year there is a large amount of green needlegrass. In the southwestern part of the area buffalograss is prominent. Western wheatgrass and blue grama are on the fine-textured soils such as those derived from the Pierre shales.

In the Nebraska sand hills warmseason grasses are dominant, mainly sand bluestem, little bluestem, and prairie sandreed. Other species in the sand hills are switchgrass, blue grama, needleandthread, and numerous forbs.

Woody species other than big sagebrush and rabbitbrush are uncommon in the area except along streams or on more favorable moisture sites (fig. 11). Some of the native shrubs are skunkbush sumac, silver buffaloberry, plums, chokecherries, and common juniper. Green ash, western cottonwood, Rocky Mountain juniper, and boxelder are the most common trees except in the Black Hills where ponderosa pine and an association of deciduous trees are dominant. Lodgepole pine is in the Black Hills and white spruce is at higher elevations in the northern part of the region.

Wildlife. This region has a large and varied wildlife population. Characteristic big game animals are mule 


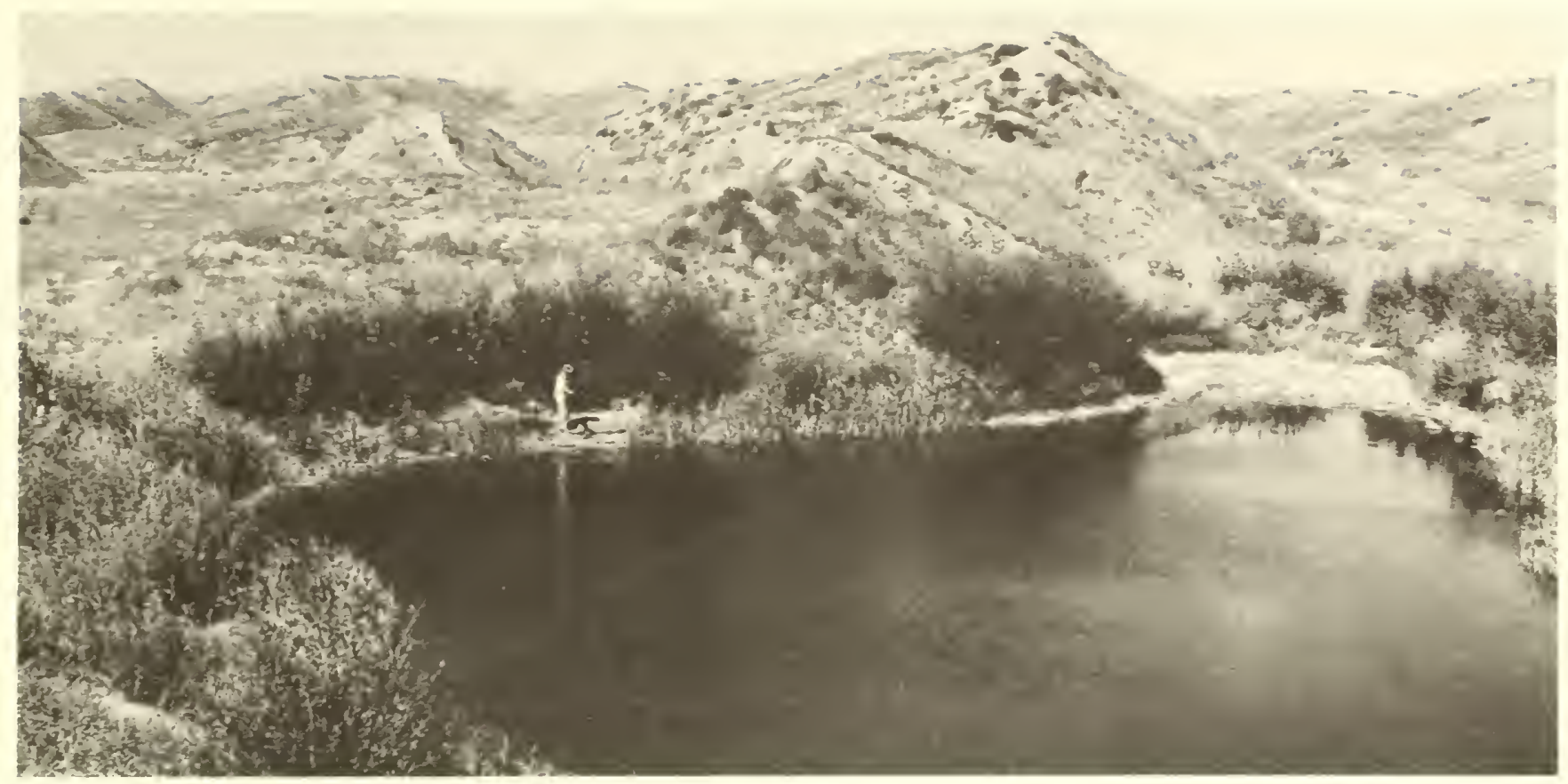

Figure 11. Wildlife habitat made from spoil banks of a lignite strip mine in North Dakota.

deer, white-tailed deer, and antelope. Elk are in the Black Hills. Upland game birds are sharptail and sage grouse. Chukar and Hungarian partridge and pheasant have been introduced successfully. Wild turkey are common in the northern part of the Black Hills of South Dakota and Wyoming where there is an intermixed forest of ponderosa pine, bur oak, other deciduous trees, and shrubs.

\section{B. Central Great Plains}

Southwestern Nebraska, western Kansas, the Oklahoma and Texas panhandles, and Colorado and New Mexico east of the Rocky Mountains. $207,000 \mathrm{mi}^{2}\left(536,000 \mathrm{~km}^{2}\right)$

\section{MLRA's}

Central High Plains (67)

Upper Arkansas Valley Rolling Plains (69)

Pecos-Canadian Plains and Valleys (70)

Central Nebraska Loess Hills (71)

Central High Tableland (72)

Rolling Plains and Breaks (73)

Southern High Plains (77)
Central Rolling Red Plains (78) Great Bend Sand Plains (79)

Climate. The mean annual precipitation is generally 14 to 20 inches ( 36 to $50 \mathrm{~cm}$ ) but ranges from 10 to 25 inches $(25$ to $64 \mathrm{~cm})$. The maximum amount occurs in summer though there are wide fluctuations from year to year (fig. 12). The mean annual temperature is $50^{\circ} \mathrm{F}\left(10^{\circ} \mathrm{C}\right)$ but increases to $60^{\circ} \mathrm{F}\left(16^{\circ} \mathrm{C}\right)$ in the southern part. The frost-free period is generally 140 to 180 days but is more than 200 days in the southern part.

Elevation and topography. Elevation is 1,500 to 3,000 feet ( 457 to $915 \mathrm{~m}$ ) over most of the area but is 6,000 feet $(1,830 \mathrm{~m})$ in the foothills. The topography is mainly undulating to rolling. The mantle of loess varies in depth.

Vegetation. In the northern part of the area blue grama and buffalograss are dominant. Other common species are western wheatgrass, hairy grama, and yucca. Little bluestem, sand sagebrush, and hairy grama are common on sandy sites.

There are inclusions of prairie sandreed, sand lovegrass, switchgrass, and needleandthread. In the panhandle regions of Oklahoma and Texas and adjacent New Mexico midgrasses and broadleaf deciduous shrubs are dominant. Little bluestem, sideoats grama, and shinnery oak are common. Other species are acacias, sand bluestem, sand sagebrush, blue grama, hairy grama, buffalograss, netleaf hackberry, mesquite, skunkbush sumac, fragrant sumac, dropseed, and indiangrass. Black grama and galleta make up a large part of the vegetation of eastern New Mexico.

Wildlife. White-tailed deer and mule deer are in the area. Ante'ope, though present, are not as numerous as in the Northern Great Plains plant growth region. The lesser prairie chicken is in the area, and the scaled quail is in the southern part of the region. Pheasant are common in irrigated areas and wild turkey have been successfully established in isolated places. 
Central Great Plains Region

Boise City, Oklahoma

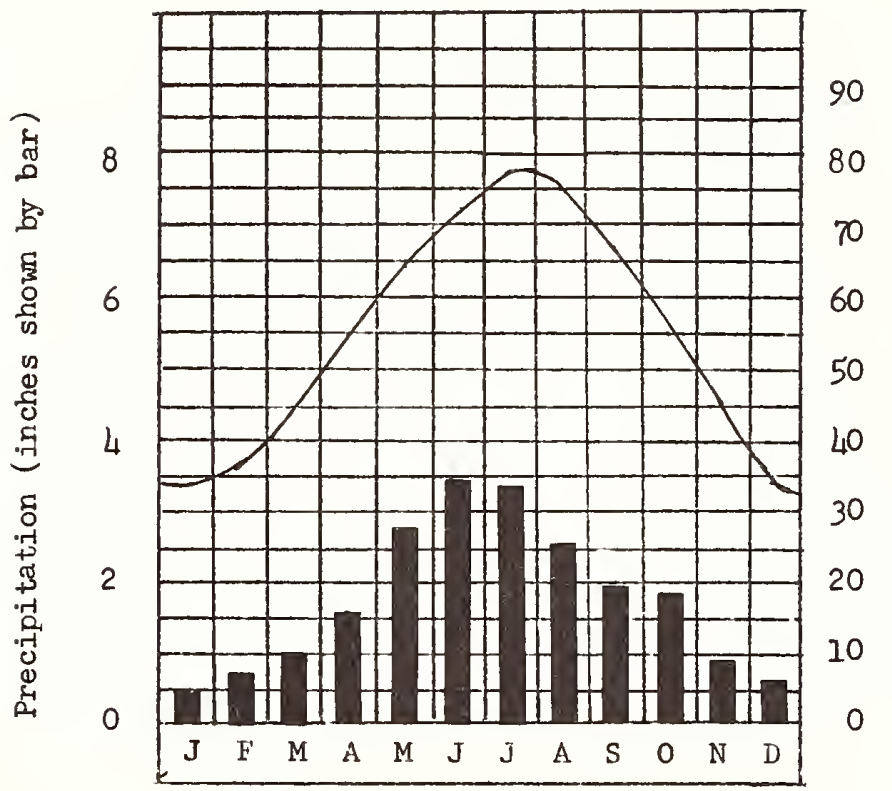

$\begin{array}{llll}\text { Longitude } & 102^{\circ} 28^{\prime} \mathrm{W} & \text { Mean annual precipitation } & 19.8 \text { inches } \\ \text { Latitude } & 36^{\circ} 43^{\prime} \mathrm{N} & \text { Mean annual temperature } & 55^{\circ} \mathrm{F}\end{array}$

Elevation 3,500 feet Frost-free period 184 days

Figure 12. Climatic graph of a station representative of the Central Great Plains Region.

\section{Southern Plains}

South and southwest Texas east of the Trans-Pecos. $68,000 \mathrm{mi}^{2}$ $\left(176,000 \mathrm{~km}^{2}\right)$

\section{MLRA's}

Edwards Plateau (81)

Texas Central Basin (82)

Rio Grande Plain (83 A, B, C)

Lower Rio Grande Valley (83 D)

Climate. The mean annual precipitation is generally 20 to 35 inches ( 50 to $64 \mathrm{~cm}$ ) but ranges from 15 inches $(38 \mathrm{~cm})$ in the west to about 35 inches $(90 \mathrm{~cm})$ along the Gulf. The maximum amount occurs in spring and autumn (fig. 13). The mean annual temperature is 60 to $70^{\circ} \mathrm{F}\left(16\right.$ to $\left.21^{\circ} \mathrm{C}\right)$, and the frostfree period ranges from 220 to more than 300 days.
Elevation and topography. Elevation ranges from sea level to about 4,000 feet $(1,220 \mathrm{~m})$. The area is mainly a broadly dissected limestone plateau.

Vegetation. About 80 percent of the area has native vegetation. It consists primarily of a dense to open stand of grass over much of the area. The overstory is mainly broadleaf deciduous trees. Creosotebush, mesquite, and acacias are dominant in the Rio Grande Valley and bluffs. Tobosa and burrograss are the most common grasses. Blackbrush acacia and mesquite are dominant in the southern part of the area. Other shrubs are guajillo, condalia, and species of cactus. The most common grasses are little bluestem, silver bluestem, threeawns, hairy grama, buffalograss, big sandbur, tanglehead, crinkleawn, twoflower trichloris, and pappusgrass. There are also areas of a savanna vegetation of sand live oak.

Wildlife. White-tailed deer, mule deer, and peccary are in the southern plateau. Wild turkey are common in some areas, and the scaled quail and white-winged dove are common native upland game birds.

\section{Northern Rocky Mountains}

Mountains of Idaho, Montana, Wyoming, and the eastern parts of Washington and Oregon. 140,000 $\mathrm{mi}^{2}\left(360,000 \mathrm{~km}^{2}\right)$

\section{MLRA's}

Northern Rocky Mountains (43)

Northern Rocky Mountain Valleys (44)

Alpine Meadows and Rockland (45)

Northern Rocky Mountain Foothills (46)

Climate. The mean annual precipitation is generally 12 to 20 inches ( 30 to $50 \mathrm{~cm}$ ) but may be more than 50 inches $(125 \mathrm{~cm})$. The mean annual temperature ranges from 35 to $50^{\circ} \mathrm{F}\left(2\right.$ to $10^{\circ} \mathrm{C}$ ), and the frostfree period is 60 to 135 days.

Elevation. The elevation ranges from 2,000 to 12,000 feet ( 610 to $3,660 \mathrm{~m})$.

Vegetation. The forests consist mainly of ponderosa pine, lodgepole pine, Douglas-fir, western white pine, western redcedar, western hemlock, grand fir, and Engelmann spruce. The mountain valleys have an open to fairly dense grassland. Bluebunch wheatgrass, Idaho fescue, rough fescue, spike-fescue, and needleandthread are the common species. Other important species are western wheatgrass, fringed sagewort, blue grama, threadleaf sedge, eriogonums, prairie junegrass, and Sandberg bluegrass.

Wildlife. Mule deer are present throughout this region and whitetailed deer are common in the foot- 
hills and valleys. Elk are common and moose are present where the habitat is suitable. The black bear is fairly common and mountain goats are on isolated sites at high elevation. The ruffed grouse is the common upland game bird.

\section{E. Central Rocky Mountains}

Colorado, eastern and central Utah, southern Wyoming, and northern New Mexico, 88,000 $\mathrm{mi}^{2}$ $\left(228,000 \mathrm{~km}^{2}\right)$

\section{MLRA's}

Wasatch and Uinta Mountains (47)

Southern Rocky Mountains and Parks (48 A, B)

Southern Rocky Mountain Foothills (49)

High Intermountain Valleys (51)

Climate. The climate varies with the elevation but is mainly in the 10- to 20 -inch ( 25 to $50 \mathrm{~cm}$ ) annual precipitation zone. The mean annual temperature ranges from 35 to $50^{\circ} \mathrm{F}$ $\left(2\right.$ to $10^{\circ} \mathrm{C}$ ), and the frost-free period ranges from 60 to 160 days.

Elevation. The elevation is 5,000 to $9,000$ feet (1,525 to $2,745 \mathrm{~m})$.

Vegetation. Many plant associations are in this area.The dominant vegetation in the higher elevations is subalpine fir, Engelmann spruce, and a large number of deciduous shrubs. Gambel oak covers large areas and quaking aspen is in old burns. Ponderosa pine and Douglasfir are dominant over much of the area. The vegetation of the valleys ranges from big sagebrush and western wheatgrass to bluebunch wheatgrass and big sagebrush or shadscale and greasewood. Juniper and pinyon woods are on lower slopes in the southern parts of the area. Skunkbush sumac, serviceberry, mountainmahogany, and needleandthread are common to this area.

Wildlife. Mule deer are common throughout the area and elk and black bear are also present. Whitetailed deer are in the foothills and
Del Rio, Texas

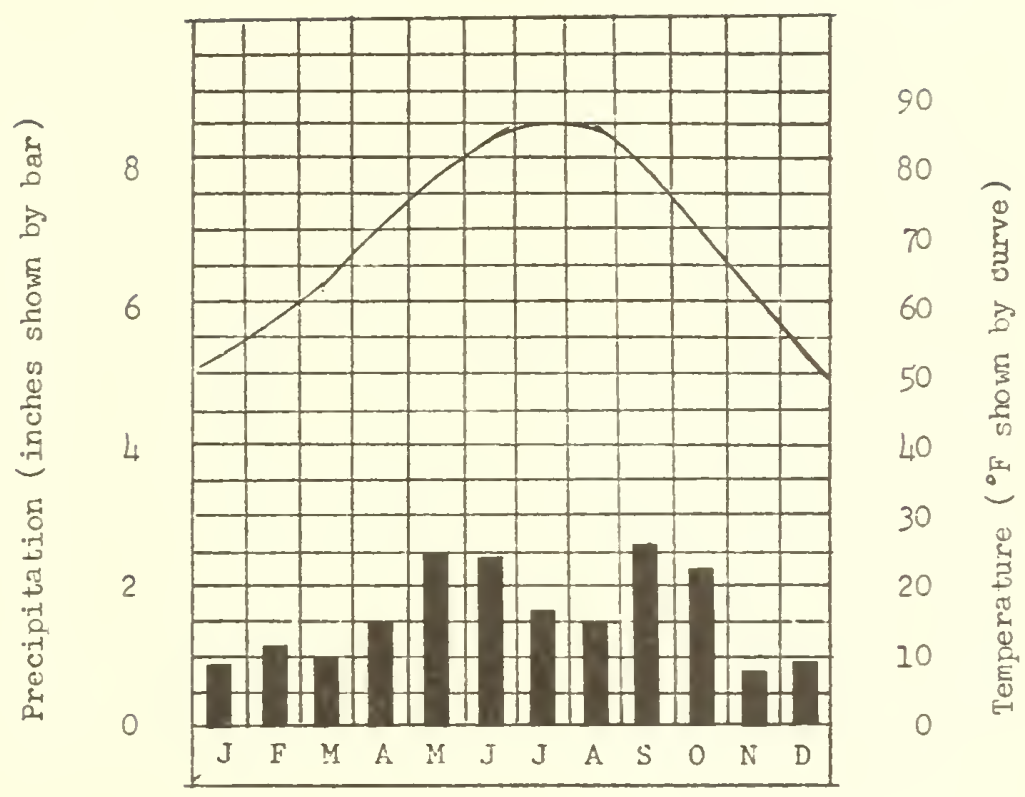

$\begin{array}{llll}\text { Longitude } & 100^{\circ} 54^{\prime} \mathrm{W} & \text { Mean annual precipitation } & 18.6 \text { inches } \\ \text { Latitude } & 29^{\circ} 21^{\prime} \mathrm{N} & \text { Mean annual temperature } & 70^{\circ} \mathrm{F} \\ \text { Elevation } & 1,000 \text { feet } & \text { Frost-free period } & 280 \text { days }\end{array}$

Figure 13. Climatic graph of a station representative of the Southern Plains Region.

valleys. Ruffed grouse is the common game bird, and band-tailed pigeon is a summer resident.

\section{F. Southern Rocky Mountains}

Western and southern New Mexico and central Arizona. 41,000 $\mathrm{mi}^{2}\left(106,000 \mathrm{~km}^{2}\right)$

\section{MLRA}

Arizona and New Mexico Mountains (39)

Climate. The climate varies with the elevation. Precipitation is generally 10 to 20 inches ( 25 to $50 \mathrm{~cm}$ ) annually but can be as much as 50 inches $(75 \mathrm{~cm})$. The precipitation occurs fairly evenly throughout the year. The maximum amount occurs from midsummer to early autumn. The mean annual temperature ranges from 40 to $65^{\circ} \mathrm{F}$ ( 4 to $18^{\circ} \mathrm{C}$ ). The frost-free period ranges from 40 days at high elevations to more than 240 days at lower elevations in the south.

Elevation. The elevation ranges from about 2,000 feet to more than 10,000 feet (610 to $3,050 \mathrm{~m}$ ).

Vegetation. In the mountains of New Mexico the main vegetation is ponderosa pine, Douglas-fir, pinyon, and juniper. Also present are dwarf maple, thinleaf alder, buckbrush, fernbush, Arizona fescue, pinedropseed. bush rockspirea, cliffbush, common juniper, blue spruce, limber pine, bitter cherry, currant, and willow. Areas of medium to high elevation have New Mexico locust, big bluestem, indiangrass, and deergrass.

In the Arizona mountains ponderosa pine is dominant. Chihuahua pine and Mexican pinyon are in the southern part of the mountains. Douglas-fir is dominant at higher 
elevations. Also present are Gambel and other species of oak, needlegrasses, threeawns, pinedropseed, buckbrush, Arizona fescue, bush rockspirea, mountain muhly, ninebark, muttongrass, common juniper, myrtle boxleaf, bristlecone pine, currant, willow, elder, and snowberry. On some sites with dwarf maple, corkbark fir and Engelmann spruce may be prominent.

Wildlife. Mule deer, elk, and peccary are in the area and white-tailed deer are in the foothills. Wild turkey have been successfully introduced in parts of the area. The band-tailed pigeon is a year-round resident.

\section{G. Palouse Prairie, Columbia Basin and Plateau}

Central and eastern Washington and parts of northern Oregon. $33,000 \mathrm{mi}^{2}\left(85,500 \mathrm{~km}^{2}\right)$

\section{MLRA's}

Columbia Basin (7)

Columbia Plateau (8)

Palouse and Nez Perce Prairies (9)

Climate. The average annual precipitation is 10 to 18 inches ( 25 to $46 \mathrm{~cm}$ ) but ranges from 6 inches $(15 \mathrm{~cm})$ to more than 20 inches $(50 \mathrm{~cm})$. The maximum precipitation occurs in winter; drought occurs in summer (fig. 14). The mean annual temperature is 45 to $50^{\circ} \mathrm{F}$ $\left(7\right.$ to $10^{\circ} \mathrm{C}$ ). The frost-free period is 120 to 175 days in most of the area.

Elevation and topography. The elevation is 1,000 to 3,500 feet ( 305 to $1,068 \mathrm{~m})$. There are gentle sloping to rolling plains with loess- and ash-mantled plateaus.

Vegetation. The natural vegetation is mainly a dense, low to mediumtall, cool-season grassland. Bluebunch wheatgrass and Idaho fescue are dominant, and Sandberg bluegrass is common in some areas. Big sagebrush is dominant over much of the area. Other vegetation is low sagebrush, black sagebrush, antelope
Palouse Prairie, Columbia Basin and Plateau Region Ellensburg, Washington

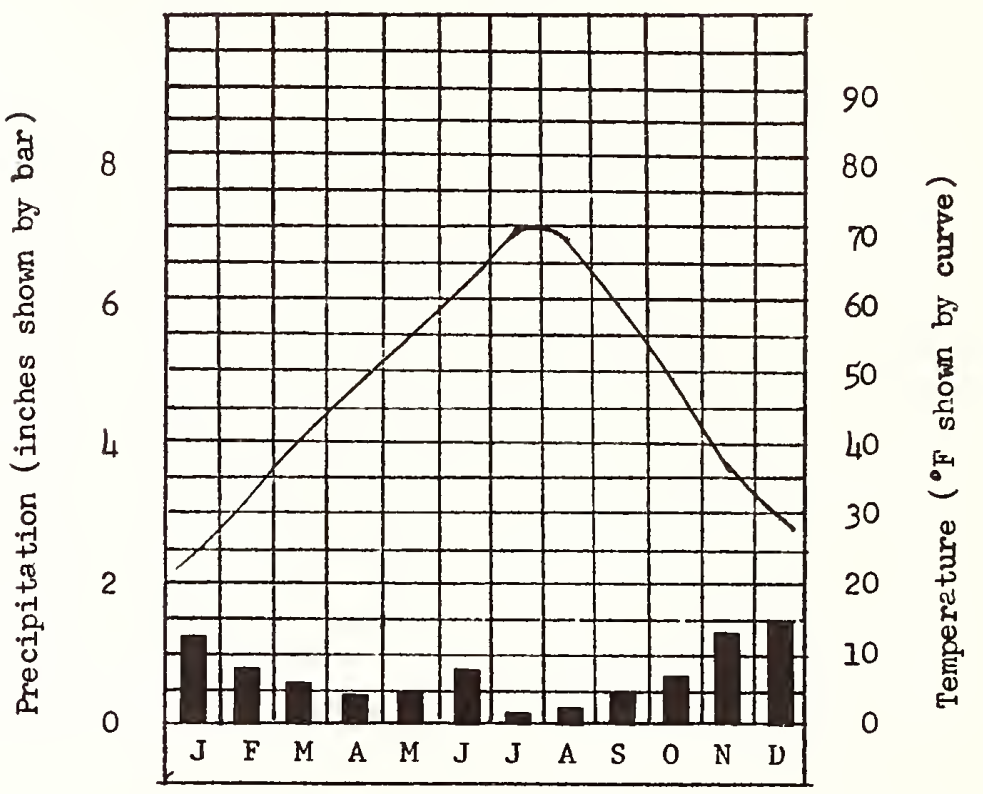

$\begin{array}{llll}\text { Longitude } & 120^{\circ} 33^{\circ} \mathrm{W} & \text { Mean annual precipitation } 8.5 \text { inches } \\ \text { Latitude } & 47^{\circ} 00^{\prime} \mathrm{N} & \text { Mean annual temperature } & 48^{\circ} \mathrm{F} \\ \text { Elevation } & 1,600 \text { feet } & \text { Frost-free period } & 142 \text { days }\end{array}$

Figure 14. Climatic graph of a station representative of the Palouse Prairie, Columbia Basin and Plateau Region.

bitterbrush, and forbs.

Wildlife. Mule deer, white-tailed deer, and antelope are in the area. Pheasant, chukar partridge, and Hungarian partridge have been successfully introduced. The sharptailed grouse is a common native upland game bird.

\section{H. Snake River Plain and Eastern Idaho}

Snake River plain of Central Oregon and southwestern Idaho to eastern Idaho. 47,000 $\mathrm{mi}^{2}(121,700$ $\mathrm{km}^{2}$ )

\section{MLRA's}

Upper Snake River Lava Plains and Hills (10)

Snake River Plains (11)

Lost River Valleys and Mountains (12)

Eastern Idaho Plateaus (13)

Climate. The average annual pre- cipitation is 10 to 15 inches ( 25 to $38 \mathrm{~cm}$ ) but ranges from 7 to 20 inches (18 to $50 \mathrm{~cm}$ ). The least amount occurs during the summer (fig. 15). The mean annual temperature is $45^{\circ} \mathrm{F}\left(7^{\circ} \mathrm{C}\right)$ but ranges from 40 to more than $50^{\circ} \mathrm{F}\left(4\right.$ to $10^{\circ} \mathrm{C}$ ). The frost-free period is 60 to 180 days.

Elevation. The elevation is 1,300 to 5,000 feet ( 397 to $1,525 \mathrm{~m}$ ) in most of the area but is greater in the foothills of eastern Idaho.

Vegetation. Bluebunch wheatgrass and big sagebrush are dominant in most of the area. Other plants are low sagebrush in the western part and black sagebrush in the east. Also present are Indian ricegrass, Idaho fescue, Sandberg bluegrass, Nevada bluegrass, species of squirreltail, and such forbs and shrubs as arrowleaf balsamroot, silky lupine, phlox, 
Snake River Plain and Eastern Idaho Region

Boise, Idaho

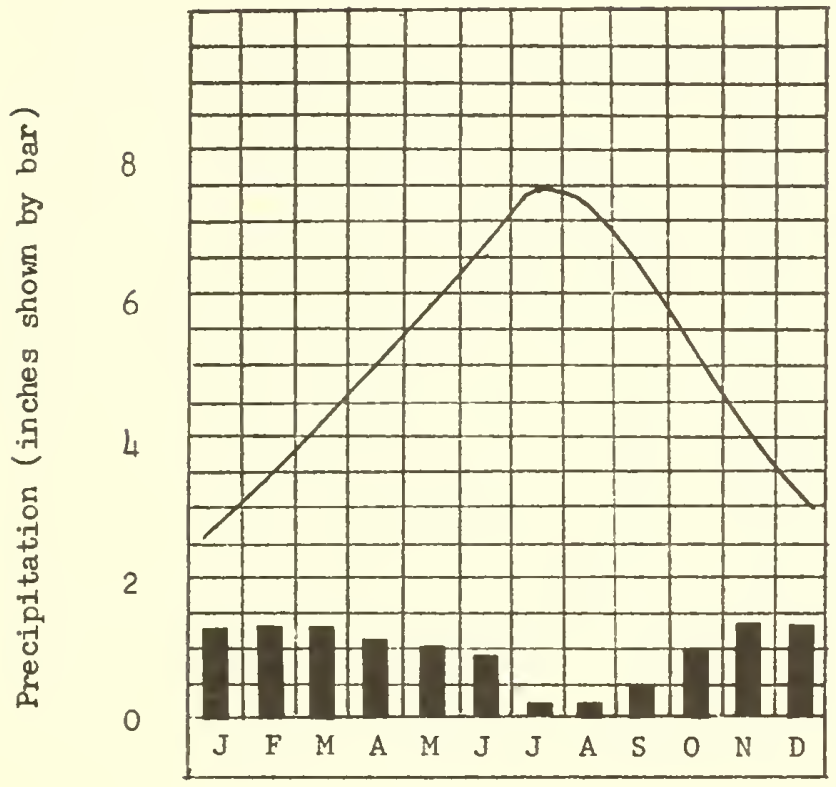

90

\section{0 \\ 70 \\ है}

60

50

40

30

20

10

0

Mean annual precipitation 11.5 inches

Longitude $116^{\circ} 121 \mathrm{~W}$

Mean annual temperature

$57^{\circ} \mathrm{F}$

Latitude

$42^{\circ} 38^{\prime} \mathrm{N}$

Frost-free period

177 days

Figure 15. Climatic graph of a station representative of the Snake River Plain and Eastern Idaho Region.

wayside gromwell, and antelope bitterbrush. Shadscale and greasewood are in some areas that also have winterfat, spiny hopsage, green molly kochia, and saltgrass species. Western juniper is in large areas of lava fields and rocky soils in southwestern Idaho and central Oregon.

Wildlife. White-tailed deer and mule deer are in the area. The chukar partridge, Hungarian partridge, and pheasant have been introduced successfully. Sharp-tailed and sage grouse are common native upland game birds.

\section{Great Basin Intermontane}

Nevada, northwestern California, southern Oregon, southern Idaho, western Utah, and northern Arizona. $230,000 \mathrm{mi}^{2}\left(595,000 \mathrm{~km}^{2}\right)$ but ranges from 40 to $60^{\circ} \mathrm{F}$ ( 4 to $16^{\circ} \mathrm{C}$ ). The frost-free period is generally 120 to 140 days but at high elevations ranges from 60 days to about 130 days.

Elevation. The elevation is mainly 3,000 to 5,000 feet $(915$ to 1,525 $\mathrm{m})$, but ranges from 2,000 to 7,500 feet ( 610 to $2,287 \mathrm{~m}$ ).

Vegetation. Several plant associations are in this area. The most common is a sagebrush association of fairly dense to open covering of low to medium-tall shrubs. This includes western wheatgrass in the northern part and black sagebrush, shadscale, and species of astragalus, rabbitbrush, and blackbrush in the southern part. There are large areas where soil conditions support pure stands of winterfat.

In some areas shadscale and greasewood are dominant. There are also species of saltbushes, but sagebrush, desert saltgrass, Indian ricegrass, winterfat, spiny hopsage, green molly kochia, wolfberries, spiny menodora (in the western part), Torrey seepweed, and others. In parts of southern Utah, Nevada, and northern Arizona blackbrush is dominant. Other vegetation is big sagebrush, ephedra species, broom snakewood, narrowleaf goldenweed, and galleta. Parts of Utah have an association of such deciduous to semideciduous shrubs as curlleaf mountainmahogany, Gambel oak, snowbrush, cliffrose, antelope bitterbrush, skunkbush sumac, roundleaf buffaloberry, pinyon, and many more. Palmer penstemon grows on disturbed sites.

Wildlife. Antelope, mule deer, and big-horn sheep are in the area.

Chukar partridge and pheasant have been introduced. The sage grouse is a common upland game bird in the northern part. Other birds and mammals as well as reptiles and amphibians are represented,. 
Great Basin Intermontane Region

Winnemucca, Nevada



90

80

70

60

50

50

40

30

20

20

10

0

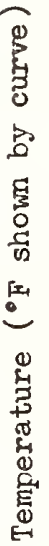

Longitude $\quad 117^{\circ} 43^{\prime} \mathrm{W}$

Mean annual precipitation 1407 inches

Latitude

$40^{\circ} 59 \cdot \mathrm{N}$

Mean annual temperature

$49^{\circ} \mathrm{F}$

Elevation

4,300 feet

Frost-free period

141 days

Figure 16. Climatic graph of a station representative of the Great Basin Intermontane Region.

\section{J. Northern and Central Intermountain Desertic Basins}

North-central to central and southwestern Wyoming and parts of western Colorado and northeastern Utah. $61,000 \mathrm{mi}^{2}\left(158,000 \mathrm{~km}^{2}\right)$

\section{MLRA's}

Northern and Central Intermountain Desertic Basins (32)

Semiarid Rocky Mountains (33)

Central Desertic Basins, Mountains, and Plateaus (34)

Climate. The mean annual precipitation ranges from 5 inches $(13 \mathrm{~cm})$ in the Big Horn Basin of Wyoming to about 16 inches $(40 \mathrm{~cm})$ in the semiarid mountains of Wyoming. The precipitation is fairly evenly distributed throughout the year. The maximum occurs in spring and summer (fig. 17). The mean annual temperature ranges from $40^{\circ} \mathrm{F}\left(4^{\circ} \mathrm{C}\right)$ in the north to $50^{\circ} \mathrm{F}\left(10^{\circ} \mathrm{C}\right)$ in the south. The frost-free period is generally 100 to 120 days, and as much as 150 days in Utah.

Elevation. The elevation ranges from 5,000 to 8,000 feet $(1,525$ to $2,440 \mathrm{~m}$ ).

Vegetation. The native vegetation consists of open to fairly dense grassland with scattered to dense areas of shrub. In the Wyoming part of the region dominant grasses are western wheatgrass, big sagebrush, plains bluegrass, and needleandthread. Other species are bluebunch wheatgrass, species of sagebrush, fourwing and Nuttall saltbushes, bud sagebrush, threadleaf sedge, winterfat, junegrass, and greasewood. Shadscale and greasewood are dominant in sites where bottlebrush squirreltail, fourwing and Nuttall saltbushes, and Indian ricegrass grow. In the low mountains and foothills of Utah and Colorado curlleaf mountainmahogany and Gambel oak are dominant. Other plants in this area are Utah juniper, bigtooth maple, Utah serviceberry, bearberry species, snowbrush, cliffrose, myrtle boxleaf, mallow ninebark, bitterbush, oaks, skunkbush sumac, and snowberry.

Wildlife. White-tailed deer and mule deer are present. Chukar partridge and pheasant are introduced species. Sage grouse is common in upland areas.

\section{K. Southern Plateaus}

West Texas, western New Mexico, and southeastern Arizona. 106,000 $\mathrm{m}^{2}\left(275,000 \mathrm{~km}^{2}\right)$

\section{MLRA's}

New Mexico and Arizona Plateaus and Mesas (36)

Southeastern Arizona Basin and Range (41)

Southern Desertic Basins, Plains, and Mountains (42)

Climate. The mean annual precipitation is 8 to 20 inches ( 20 to $50 \mathrm{~cm}$ ). The maximum amount occurs late in spring and in summer (fig. 18). The mean annual temperature ranges from 45 to $70^{\circ} \mathrm{F}$ ( 7 to $21^{\circ} \mathrm{C}$ ), and the frost-free period is 120 to 240 days.

Elevation. The elevation is 2,500 to 7,000 feet (763 to $2,135 \mathrm{~m}$ ).

Vegetation. Numerous plant associations are in this region. Western Texas and adjacent New Mexico have a shrub and short grass association. The dominant species are tarbush and creosotebush. Other plants are mescat acacia, catclaw, lechugilla, fourwing saltbush, gyp grama, black grama, sotol, ephedra, 
ocotillo, sticky snakeweed, tobosa, beargrass, mesquite, alkali sacaton, blue yucca, and soaptree yucca. There are large open grasslands where blue grama and tobosa are dominant and where sideoats grama, black grama, hairy grama, muhly, cholla, and hairy tridens also grow.

In southeastern Arizona and southern New Mexico the dominant plants are black grama, tobosa, and creosotebush. Others are mescat acacia, cane bluestem, threeawns, gramas, curlymesquite, galleta, mentzelia, bush muhly, cactus, mesquite, dropseeds, blue and soaptree yuccas, and zinnias.

In large parts of the New Mexico and Arizona plateaus, open stands of oneseed juniper are dominant. Utah juniper and pinyon pine are in the eastern part and singleleaf pinyon is in the western part. The northern area has big sagebrush, western wheatgrass, sideoats grama, blue grama, Indian ricegrass, and sand dropseed. Shrubs include species of buckbrush, ninebark, rabbitbrush, blackbrush, apacheplume, junipers, bitterbrush, and oaks.

Wildlife. White-tailed deer, mule deer, peccary, and some antelope are in the area, as well as scaled and mearns quail, band-tailed pigeon, and white-winged dove.

\section{Cascade-Sierra Nevada}

About $17,000 \mathrm{mi}^{2}\left(44,000 \mathrm{~km}^{2}\right)$ of the eastern slope of the Cascade range of Oregon and Washington and about $22,000 \mathrm{mi}^{2}\left(57,000 \mathrm{~km}^{2}\right)$ of the California Sierra Nevada.

\section{MLRA's}

Cascade Mountains (eastern slope) (6)

Sierra Nevada (22)

Climate. The precipitation varies with elevation but ranges from 12 inches to more than 60 inches ( 30 to $150 \mathrm{~cm}$ ).

Northern and Central Intermountain Desertic Basins Region Rock Springs, Wyoming


90 80 70 60 50 40 30

Longitude $109^{\circ} 12^{\prime} \mathrm{W} \quad$ Mean anmual precipitation 8.8 inches

Latitude $47^{\circ} 35^{\prime} \mathrm{N} \quad$ Mean annual temperature $42.5^{\circ} \mathrm{F}$

Elevation 6,300 feet Frost-free period 100 days

Figure 17. Climatic graph of a station representative of the Northern and Central Intermountain Desertic Basin Region.

Vegetation. The area is mainly forested. On the eastern Cascade range ponderosa pine is dominant. The main grasses are bluebunch wheatgrass, pinegrass, and Idaho fescue. Other plants are foambush, greenleaf manzanita, snowbrush, curlleaf mountainmahogany, Pacific ninebark, Douglas-fir, bitterbrush, and species of snowberries.

In the Sierra range of California, whitebark pine, foxtail pine, lodgepole pine, and mountain hemlock are dominant. Other speices are eriogonum, limber pine, cinquefoil, and currants.

Wildlife. White-tailed deer and mule deer are present. Mountain grouse and California quail are native game birds, and chukar partridge and Hungarian partridge have been introduced.

\section{California Valleys and Foothills}

Central California valleys and Sierra Nevada foothills, 27,000 $\mathrm{mi}^{2}$ $\left(70,000 \mathrm{~km}^{2}\right)$.

\section{MLRA's}

Sacramento and San Joaquin Valleys (17)

Sierra Nevada Foothills (18)

Climate. The mean average precipitation ranges from 5 inches $(13 \mathrm{~cm})$ in parts of the central valley to 25 inches $(64 \mathrm{~cm})$ or more in the foothills. Summers are long and dry (fig. 19). The mean annual temperature ranges from $55^{\circ} \mathrm{F}$ to more than $65^{\circ} \mathrm{F}\left(13\right.$ to $\left.18^{\circ} \mathrm{C}\right)$, and the frostfree period ranges from 135 days at the higher elevations to 250 to 350 days in the valley. 
Southern Plateaus Region

Santa $\mathrm{Fe}$, New Mexico

ڤ્木

8

6

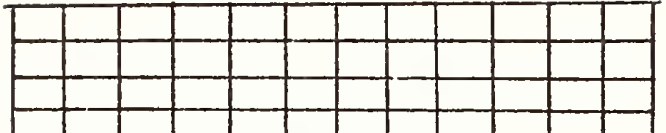

4

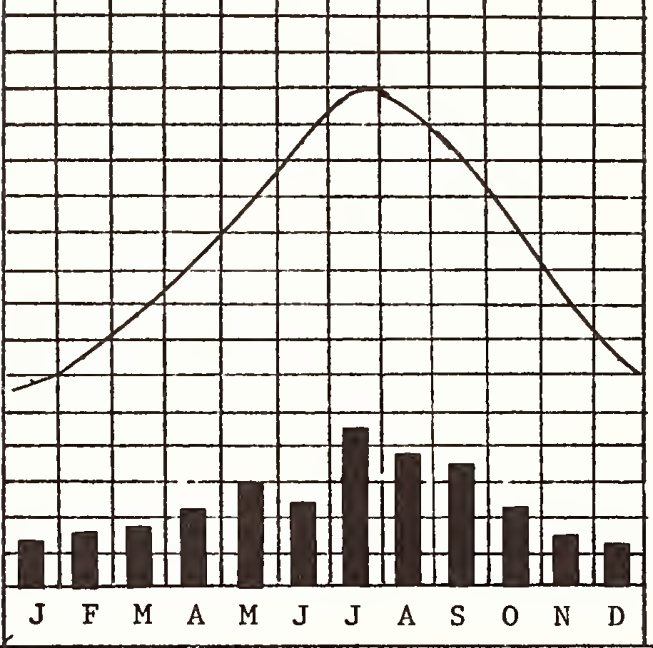

Longitude

$106^{\circ} 05^{\prime} \mathrm{W}$

Mean annual precipitation 14.2 inches

Latitude

$35^{\circ} 40^{\prime} \mathrm{N}$

Mean arnual temperature

$48^{\circ} \mathrm{F}$

Elevation

7,000 feet

Frost-free period

178 days

Figure 18. Climatic graph of a station representative of the Southern Plateaus Region.

Elevation. The elevation ranges from sea level to 500 feet $(153 \mathrm{~m})$ in the valley and in the foothills rises to more than 2,500 feet $(763 \mathrm{~m})$.

Vegetation. The dominant vegetation in the valley is needlegrasses. In addition there are poverty threeawn, blue wildrye, beardless wildrye, California poppy, lupines, melicgrasses, and introductions of oats, bromes, and fescues. A large part of the central valley has dominant marsh vegetation such as common tule, California bulrush, Olney bulrush, other bulrushes, and cattails. California live oak is common on the valley floor.

Vegetation in the foothills ranges from broadleaf evergreen to semideciduous forest mixed with needleleaf evergreen trees. The dominant species are Coulter pine, Digger pine, and several species of oaks.
Others are buckbrush ceanothus, California redbud, California yerbasanta, California buckthorn, oakwoods gooseberry, and Californialaurel. Other areas are dominated by such broadleaf sclerophyll shrubs as greasewood, chamise, and manzanita.

Wildlife. Waterfowl are abundant. The California quail is a common native game bird and pheasant have been introduced.

\section{N. Southwestern Desert}

Southern California, southwestern Arizona, and southern Nevada. $83,000 \mathrm{mi}^{2}\left(215,000 \mathrm{~km}^{2}\right)$

\section{MLRA's}

Sonoran Basin and Range (30)

Imperial Valley (31)

Central Arizona Basin and Range (40)
Climate. The mean annual precipitation ranges from 2 inches (5 $\mathrm{cm}$ ) at low elevations to 10 inches $(25 \mathrm{~cm})$ at the higher elevations (fig. 20). The mean annual temperature ranges from 60 to $75^{\circ} \mathrm{F}$ (16 to $24^{\circ} \mathrm{C}$ ), and the frost-free period ranges from 225 to 350 days.

Elevation. The elevation ranges from below sea level to about 4,000 feet $(1,220 \mathrm{~m})$.

Vegetation. Three major plant associations are in the area. Most of the northern part has a creosotebush association and also has joshuatree, desertbroom, white brittlebrush, white bursage, Anderson wolfberry, and desert globemallow.

There is a creosotebush-white bursage association with catclaw acacia, blue paloverde, yellow paloverde, California dalea, smokethorn dalea, white brittlebrush, barrelcactus, ocotillo, triangle bursage, big galleta, wolfberry, tesota, cacti, mesquite, and bush muhly.

Another association includes shrubs, low trees, and many succulents. The dominant plants are foothills paloverde and species of pricklypear cactus. Other plants are whitethorn acacia, catclaw, falsemesquite, spiny hackberry, introduced species of ecucalyptus, blue paloverde, saguaro, lotebush, skunkbrush sumac, Englemann echinocereus, white brittlebrush, longleaf ephedra, southwest barrelcactus, ocotillo, triangle bursage, slender janusia, sangre-de-cristo, creosotebush, wolfberries, tesota, Engelmann pricklypear, mesquite, jojoba, big galleta, and bush muhly.

Wildlife. Desert subspecies of mule and white-tailed deer, as well as Sonoran antelope, peccary, big-horn sheep, coatimundi, chuckwalla, and gila monster are in the area. Game birds are gambel quail and whitewinged dove. 


\section{Selected plant materials}

This section gives brief descriptions of approximately 200 species of plants that have value on mined lands in the West. Information on the adaptation and unique characteristics of released cultivars is included. The criteria for the inclusion of a species are (1) it has been proved; (2) it is being tested and shows promise; (3) the species is believed to have potential for one of of the uses to which mined lands may be reclaimed; and (4) commercial sources of planting materials are available or could be developed.

General adaptation to precipitation zones, soil textures, and plant growth regions, as described in the preceding section, are included in table 1. Local slope, exposure, precipitation effectiveness, and regime may necessitate adjustments. A forage species with insufficient moisture may persist and provide adequate ground cover. A species may be perennial or evergreen in one climate and annual or deciduous in another; it may be a pest in one area but important in another. One common name is seldom used universally for one species; a common name may even refer to a different species. Some of the species may be native to some parts of the country but introduced into particular areas in the West.

For specific performance and availability of planting materials the local SCS, Extension Service, or other appropriate agency office should be consulted.

Information on rate of seeding per acre is included in table 2.

Most of the information in this section was drawn from the experiences and observations of SCS personnel in the West and from the reports of SCS plant materials centers. Many references were used for species characteristics and ranges of adaptation and are noted in the list of references.

Eresno, California

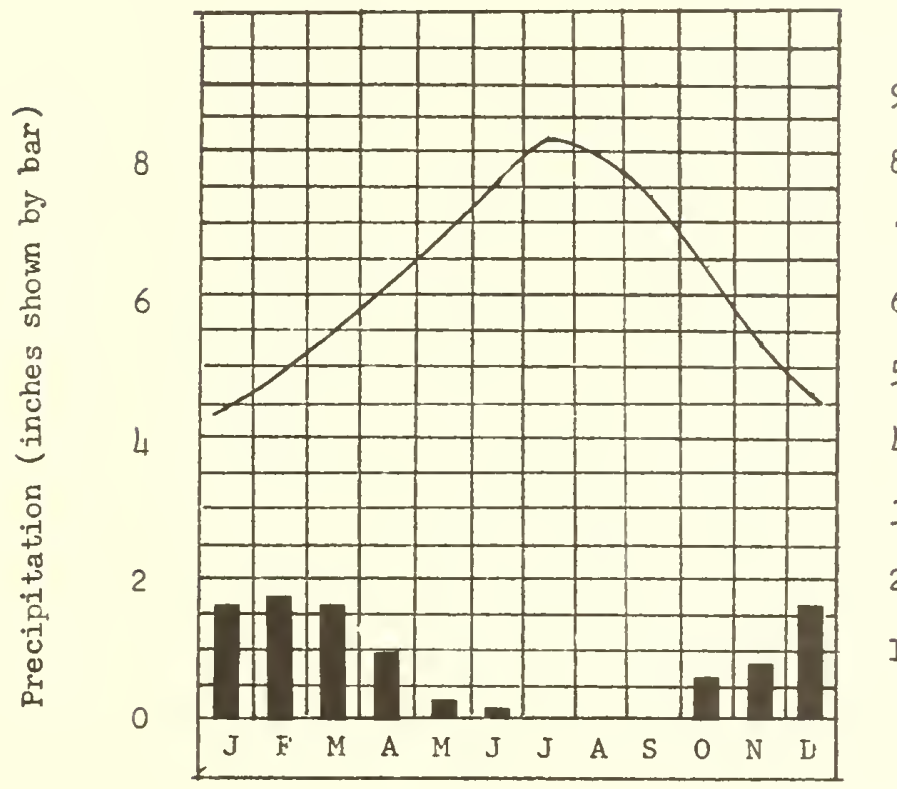

90

80

70

60

50

40

30

20

10

0



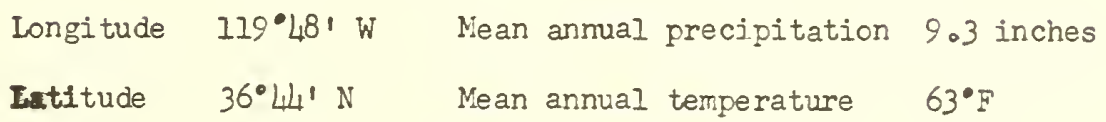

Elevation 300 feet

Frost-free period

295 days

Figure 19. Climatic graph of a station representative of the California Valleys and Foothills Region.

Additional information on plants is being developed under the leadership of the Botany and Range Science Department of Colorado State University at Fort Collins. This consists of a computerized data bank that will eventually include 250 to 300 bits of information on as many as 4,000 species. Taxonomic, geographic, ecologic, biologic, and economic data are being stored in this system, referred to as the Plant Information Network. This will become a valuable tool for the selection of plants for many uses.

For the purposes of this discussion and to aid in selection, the plants are grouped in categories:

Grasses: native grasses for forage and diversity, introduced grasses for forage, grasses primarily for soil stabilization, grasses for sandy lands, and grasses for saline-alkaline sites.
Forbs: native forbs and introduced forbs.

Woody plants: native trees, native shrubs, introduced trees, and introduced shrubs.

These categories are further grouped into arid, semiarid, and mesic sites, and into warm- and coolseason species. Definitive ranges of adaptation cannot be drawn for each species in an area covering parts of 17 states because of differences in precipitation effectiveness and patterns. The species adaptation to soils will vary with climate though this is less significant on disturbed lands and artificially created soils. Temperature patterns and extremes are also important in plant adaptation because most species have definite ranges of tolerance to heat and cold. 
For the purpose of this publication, arid sites are those with less than 10 inches $(25 \mathrm{~cm})$ mean annual precipitation. Semiarid sites are those that have about 10 to 16 inches ( 25 to $40 \mathrm{~cm}$ ) mean annual precipitation. The plants included for mesic sites generally require 16 inches $(40 \mathrm{~cm})$ as a minimum mean annual precipitation, or possibly less in cooler climates or at higher elevations. Included with the species in this category are those limited to moderately moist to moist or irrigated areas.

Many of the species mentioned are adapted to more than one of the categories but are included in the one to which they are most common or will be most used. The cultivars are included, except for the common species for which there are many cultivars such as tall fescue and smooth brome. The currently known general adaptation of cultivars to major land resource areas is provided. Release data and the sources of grass breeders and foundation seed is given in Agricultural Handbook 170, "Grass Varieties in the United States."

Plant growth regions are capitalized in the text (Southern Plateaus, Great Basin Intermontane, etc.) and refer to the areas shown on the maps.

\section{Grasses}

\section{Native grasses for forage and diversity}

These species are grouped as warm-season plants, cool-season plants, and according to their adaptation to semiarid or mesic environments.

Warm-season grasses adapted to semiarid sites include species limited to warm climates and others that have a wide range of adaptation. Six species of this group (little bluestem, sideoats and blue gramas, buffalograss, sand lovegrass, and plains lovegrass) extend their range into the Northern Great Plains plant growth region. The warm-season flora

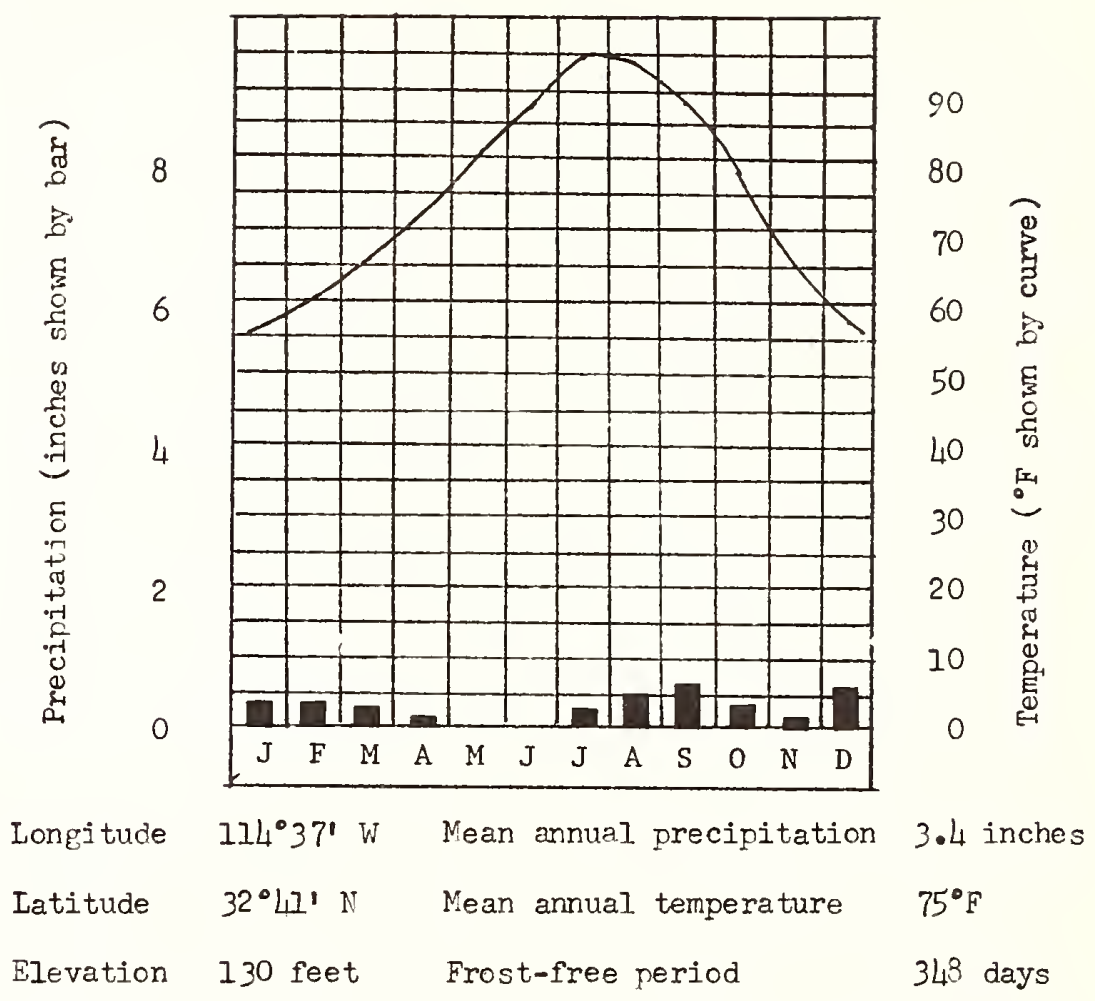

Figure 20. Climatic graph of a station representative of the Southwestern Desert Region.

evolved and is confined to an area with adequate summer precipitation. These plants are of little use in areas with low summer precipitation.

\section{Warm-season grasses for the South- west}

Cane bluestem, Andropogon barbinodis Lag., is a warm-season, perennial bunch grass of the Southern Plains and Southern Plateaus plant growth regions. Cane bluestem grows in the southern part of the Central Great Plains plant growth region and at elevations as high as 6,000 feet $(1,830 \mathrm{~m})$ in the Southern Rocky Mountains plant growth region. It is a good forage grass adapted to sandy loam to loamy calcareous soils with a $\mathrm{pH}$ range of 7.2 to 8.0 that are overflowed frequently, and to gravelly footslopes with a good soil-moisture relationship. Seed for reseeding rangelands in western Texas is available in limited quantities from harvests of native stands.

Green sprangletop, Leptochloa dubia (H.B.K.) Nees, is a relatively short-lived species native to the Southern Plateaus and Southern Plains plant growth regions and the southern part of the Central Great Plains plant growth region. Seed from harvest of native stands is used in range seeding mixtures. Green sprangletop is adapted to rocky hills and canyons and is seldom found on deep clays or deep sands. It is grazed by all classes of livestock.

'Marfa' green sprangletop was informally released for use in west Texas in MLRA's 42 and 81. It is not generally available commercially.

Plains bristlegrass, Setaria macrostachya H.B.A., is a short-lived perennial bunch grass that grows 
about 2 feet $(60 \mathrm{~cm})$ tall. It is native to the Southern Plains and Southern Plateaus plant growth regions and northward into Colorado and Oklahoma in the Central Great Plains plant growth region. It provides high quality forage when green and succulent but becomes strawy after maturity. The seeds are eaten by birds. It grows mainly on sandy to sandy loam soils and is usually associated with shrubs. Plains bristlegrass is useful in range seedings, critical area stabilization, and reclamation of disturbed areas. A limited amount of seed is available and has been used in seeding mixtures on some range sites in the Rio Grande Plains area north through the Texas Panhandle.

Arizona cottontop, Tricachne californica (Benth.) Chase, is a native, warm-season bunch grass growing in the Central Great Plains, Southern Rocky Mountains, Southern Plains, Southern Plateaus, and Southwestern Desert plant growth regions. It grows about 2 feet (60 $\mathrm{cm})$ tall on dry mesas and rocky hills between 1,000 and 6,000 feet ( 305 and $1,830 \mathrm{~m}$ ) in elevation. Normally, Arizona cottontop is a small percentage of the complete vegetation but contributes significantly to the forage production of a site because of its rapid response to summer precipitation (Leithead, et al. 1971). It is grazed by all classes of livestock.

Arizona cottontop is useful in range seeding, critical area stabilization, environmental protection, and mined land reclamation. Seed combining 20 percent Arizona cottontop and 80 percent sideoats grama was planted with a rangeland drill.

Arizona cottontop was first to grow and provided soil protection during the first 1 to 2 years until the sideoats grama was well established. Arizona cottontop seed is fluffy and cannot be harvested with conventional equipment. Harvesting field tests have been made with a grass seed stripper.

Seed is not generally available. The accession PMT-389 was informally released in 1961 for use in MLRA 42. Seed of this accession is available only in limited quantity.

Mountain muhly, Muhlenbergia montana (Nutt.) Hitchc., is a bunch grass that grows from western Texas north to Montana and west to central California on mesas and rocky hills. It is 6 inches $(15 \mathrm{~cm})$ to about 18 inches $(46 \mathrm{~cm})$ tall, depending on the site, and grows mainly on open grasslands and open mountain forests at 5,000 to 7,000 feet $(1,525$ to $2,135 \mathrm{~m}$ ). Though not evaluated, this species appears to have potential for use on mined lands.

Bush muhly, Muhlenbergia porteri Scribn., is a large bushy perennial bunch grass with evergreen stems. It grows 18 to 36 inches (46 to $90 \mathrm{~cm}$ ) tall. It is native from south and west Texas to the Southwestern Desert plant growth region of Arizona and the southern part of the Great Basin Intermontane plant growth region. It is palatable to all classes of livestock. Seed is not available at present.

Spike muhly, Muhlenbergia wrightii Vasey, is a warm-season, tufted native bunch grass with short rhizomes. It grows 8 to 20 inches $(20$ to $50 \mathrm{~cm})$ tall. It is adapted to a wide variety of soil types of the upper pinyon-juniper and ponderosa pine vegetation zones at 3,800 to 9,000 feet $(1,160$ to 2,745 $\mathrm{m}$ ) in Colorado, New Mexico, Utah, Arizona, and Nevada. It is an excellent soil binder. Spike muhly is palatable to all classes of livestock and is excellent forage for deer and elk.

'El Vado' spike muhly was released for soil stabilization and revegetation. It is recommended for use in MLRA's 36, 37, 39, 41, 42, $48 \mathrm{~A}$, and 49.

Sod-forming grasses for semiarid sites in the Southwest

Black grama, Bouteloua eriopoda
(Torr.) Torr., is a major grass of arid and semiarid grasslands in Arizona, New Mexico, and Texas. It forms a weak sod by rooting at the nodes of the slender stems. It grows 12 to 24 inches ( 30 to $60 \mathrm{~cm}$ ) tall. Black grama has excellent resistance to drought. It has good palatability and feeding value in summer and winter. It is excellent for range seedings and stabilization of critical areas and roadsides.

'Nogal' black grama has excellent seedling vigor, above-average ability to propagate by rooting nodes, and good seed production. It is recommended for use in MLRA's 39 and 42.

'Sonora' black grama was selected from collections in Arizona and New Mexico. It is recommended for use in MLRA's 36, 39, 40, and 41 at elevations of 3,500 to 6,000 feet $(1,067$ to $1,830 \mathrm{~m})$.

Curlymesquite, Hilaria belangeri (Steud.) Nash, is a warm-season, stoloniferous grass (fig. 21). It is native to the Southern Plains, southern part of the Central Great Plains, Southern Rocky Mountains, Southern Plateaus, and Southwestern Desert plant growth regions. Curlymesquite is a valuable range grass. It grows on dry deep clay soils to gravely or rocky soils at 1,000 to 6,000 feet ( 305 to $1,830 \mathrm{~m}$ ). It is palatable and cures well on the stem. It has potential for use on mined lands. No cultivars are available.

Galleta, Hilaria jamesii (Torr.) Benth., is a slightly spreading grass distributed from western Texas to Arizona and California and north into southwestern Wyoming, mainly at elevations of 4,000 to 7,000 feet $(1,220$ to $2,135 \mathrm{~m})$. It is palatable to livestock during the growing season but harsh and unpalatable after maturity. It is a drought-resisant species. No cultivars are available. Seed is available in limited quantity.

Tobosa, Hilaria mutica (Buck1.) Benth., is a slightly spreading grass native from western Texas to Ari- 


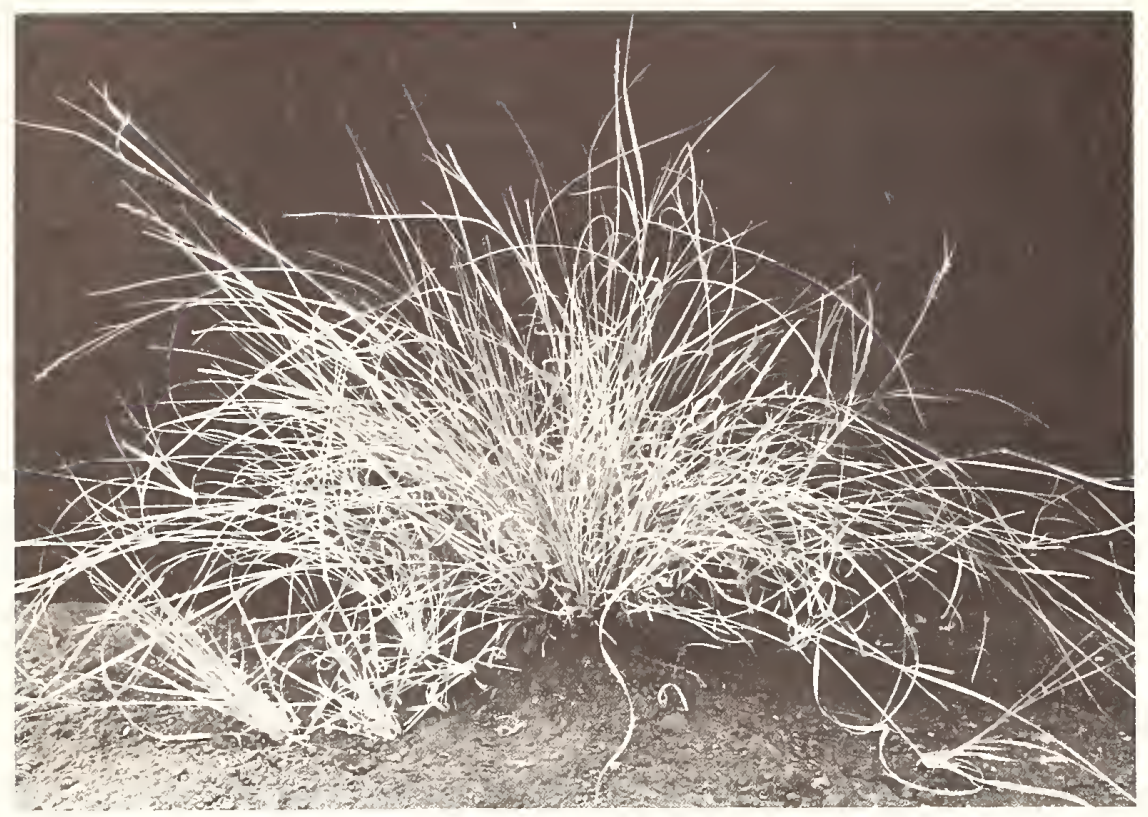

Figure 21. Curlymesquite (Hilaria belangeri).

zona in the Southern Plains, Southrn Plateaus, and Southern Rocky Mountains plant growth regions. It is most abundant in southern New Mexico and Arizona, especially on heavy soils subject to flooding during the rainy season. It is moderately palatable during the growing season. It is generally found at 2,000 to 6,000 feet $(610$ to $1,830 \mathrm{~m})$. No cultivars are available.

Big galleta, Hilaria rigida (Thurb.) Benth., is a coarse, slightly spreading grass growing at 100 to 4,000 feet $(30$ to $1,220 \mathrm{~m})$ in the Southern Rocky Mountains and Southwestern Desert plant growth regions. It tolerates drought well. No cultivars are available.

\section{Major warm-season grasses for semiarid sites in the Great Plains}

Numerous ecotypes are present in the following wide-ranging species.

These species are almost always seeded in mixtures, whether for range seedings or critical area stabilization. Cultivars are available for many areas.

Little bluestem, Andropogon scoparius Michx., (Schizachyrium scoparium (Michx.) Nash), is a major species of the Central Great Plains plant growth region but is also important from Canada to southern Texas. Little bluestem grows on drier sites than big bluestem. Several cultivars are available for the Central and Northern Great Plains plant growth regions.

'Aldous' little bluestem is a selection from the Flint Hills area of Kansas. 'Aldous' is moderately late to mature and is recommended for use in MLRA's 71 and 73 of Nebraska and Kansas and east of this area.

'Blaze' little bluestem is a bright green to dull green late-maturing cultivar that turns a deep red at maturity. It is valuable for range seedings, critical area stabilization, and native landscaping. It is recommended for use in MLRA's 71 and 73 in Nebraska and east of this area.

'Camper' little bluestem is moderately late in maturing. It has a broad genetic composition. It is recommended for use throughout Nebraska and adjacent areas in MLRA's 65, 66, 71, and 73.

'Cimarron' little bluestem is a composite from many sites in southwestern Kansas and the panhandle of Oklahoma. It is recommended for use in MLRA's 67, 72, 73, and 77.

'Pastura' little bluestem was developed from a collection made at about 6,500 feet $(1,982 \mathrm{~m})$ near Rowe, New Mexico, in a 14-inch $(36 \mathrm{~cm})$ mean annual precipitation zone. It is well adapted to extremes in temperature and precipitation and establishes well under adverse range conditions. It is recommended for use in MLRA's 67, 69, 70, and 77.

Sideoats grama, Bouteloua curtipendula (Michx.) Torr., is a major warm-season, slightly spreading bunch grass. It is distributed over much of the eastern and central United States (fig. 22). The primary use of sideoats grama is in the Central and Northern Great Plains plant growth regions, but it grows in the Southern Plains, Southern Plateaus, and Southern Rocky Mountains plant growth regions. It is usually seeded in mixtures with bluestems. Seed of several released cultivars is available.

'Butte' sideoats grama is a relatively early maturing cultivar developed from collections in Holt and Platte Counties, Nebraska. It has outstanding seedling vigor. 'Butte' sideoats grama is recommended for use in MLRA's 60, 63, 64, 65, 66, 67, 7172 and 73 .

'Coronado' sideoats grama was developed from a collection in eastern New Mexico and is recommended for use in MLRA's 77, 78, and 79 .

'El Reno' sideoats grama is from a bulk collection near El Reno, Oklahoma. It is recommended for use in MLRA's 75, 76, and 78, and east of this area.

'Pierre' sideoats grama was developed from the direct increase of a collection made in central South Dakota. It is a winter-hardy selection that performs well as far north as Montana, 'Pierre' is recommended for use in range seedings and critical area stabilization in MLRA's 53B, 53C, 54, 58C, 58D, $60,63,64,65$ and 66 . 
'Premier' sideoats grama is a selection from Mexico and is recommended for use in west-central Texas in MLRA's 78, 81 and 82.

'Trailway sideoats grama was developed from a collection in Holt County, Nebraska. It is recommended for use in MLRA's 71 and 73.

'Tucson' sideoats grama is from a collection near Douglas, Arizona, and is recommended for use in MLRA's 41 and 42.

'Uvalde' sideoats grama is recommended for use in MLRA's 81, 82, $83 \mathrm{~A}$, and $83 \mathrm{~B}$. Seed is usually in short supply.

'Vaughn' sideoats grama was originally collected near Vaughn, New Mexico. It tolerates drought and has excellent seedling vigor. It is recommended for use in MLRA's $36,39,48,67,69,70$, and 77 .

Blue grama, Bouteloua gracilis (H.B.K.) Lag., is a major warmseason grass throughout the Great Plains. It is used for grazing and erosion control. It forms a dense sod by means of creeping growth and produces a high-quality forage. It is winter hardy and tolerates drought. Blue grama grows on a wide range of soils and is well adapted to clayey, rolling upland soils. This species has considerable variability. One cultivar has been released.

'Lovington' blue grama is from a bulk field collection made near Lovington, New Mexico, at 3,900 feet $(1,190 \mathrm{~m})$ in an area with 14 inches $(36 \mathrm{~cm})$ mean annual precipitation. It was selected for its outstanding seedling vigor and forage production. It is well adapted for use on upland sites on mediumtextured to fine-textured soils in eastern New Mexico, northwestern Texas, and southeastern Colorado in MLRA's 39, 67, 69, 70, and 77.

Buffalograss, Buchloe dactyloides (Nutt.) Engelm., is a low-growing grass that forms a sod by spreading with stolons. It grows mainly in shortgrass associations of the Great Plains from North Dakota to Texas

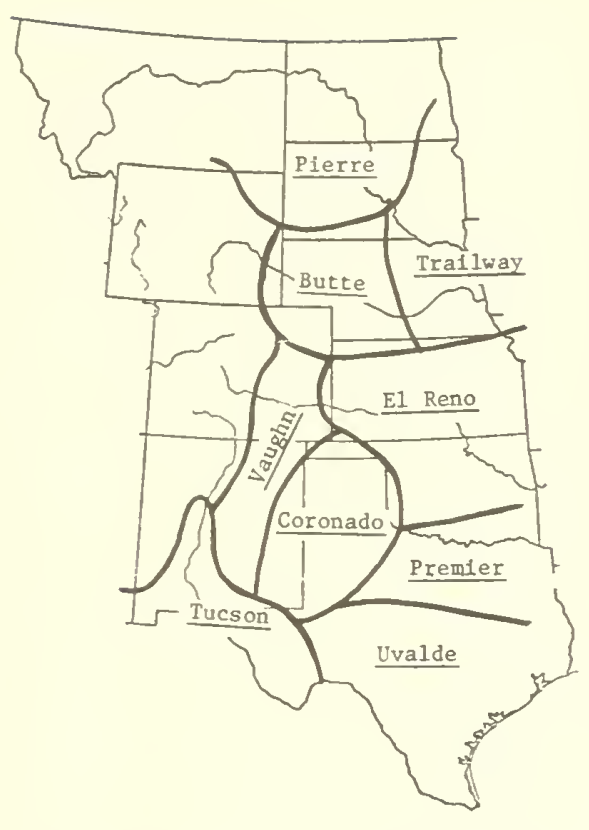

Figure 22. Approximate areas of adaptation of cultivars of sideoats grama.

and is most commonly found on clayey to clay flats. There is considerable variations in the species, but ecotypes can be moved long distances to the north where soil stabilization or turf is the planned use and seed production is not essential. Most seed has been obtained from harvests of nearly pure stands.

'Texoka' buffalograss was developed from 10 clones selected from Texas, Oklahoma, and Kansas sources. 'Texoka' has potential for high seed production and is superior in forage production to most commercial seed harvested from native stands. 'Texoka' is well adapted to northwestern Texas, western Oklahoma, and western Kansas in MLRA's 67, 70, 72, 73, 77, 78, and 79. It has performed well over a wide area.

'Sharp's Improved' buffalograss is similar to 'Texoka' and is adapted to the same area. It has performed well over a wide area.
Plains lovegrass, Eragrostis inter. media Hitchc., is a warm-season, perennial bunch grass that grows 2 to $31 / 2$ feet $(60$ to $100 \mathrm{~cm})$ tall. It is distributed from southern Texas north to Oklahoma and west to California. It grows on dry upland soils ranging in texture from clay to sand. Plains lovegrass provides good livestock forage. The seed is eaten by upland game birds. Plains lovegrass usually grows with other species and is not considered a dominant. It has potential for use on disturbed areas.

Sand lovegrass, Eragrostis trichodes (Nutt.) Wood, is an important warm-season bunch grass of the Southern Plains, Central Great Plains, and southern part of the Northern Great Plains plant growth regions. It grows well on a wide range of soils but is most common on soils with sandy or sand textures. It is usually seeded in mixtures with such other warm-season species as bluestems and gramas. Three cultivars have been released.

'Bend' sand lovegrass is a composite selected from south-central Kansas and adjacent areas in Oklahoma. It is recommended for use in Oklahoma and Kansas in MLRA's $72,73,75,76,77,78,79,80 \mathrm{~A}$, and $84 \mathrm{~A}$.

'Mason' sand lovegrass was originally collected near Mason, Texas. It is recommended for use on sandy lands in MLRA's 77, 78, 81, and 82. Seed is not now available.

'Nebraska 27' sand lovegrass is a winter-hardy, relatively long-lived strain. It is recommended for use in MLRA's 64, 65, 66, 67, 71, 72, anc 73 in Nebraska and adjacent areas.

\section{Major warm-season grasses for mesic sites in the Great Plains}

Three tall prairie grasses (big bluestem, switchgrass, and yellow indiangrass) are included in this group although they are restricted to mesic sites. The three species range from southern Texas to the Dakotas. They are composed of many eco- 
types and have restricted ranges of adaptation. Their use in reclamation is limited to favorable sites. They are valuable forage plants that are generally seeded in mixtures with other species. They can also be used as single species to extend the growing season and to augment the summer slump in forage production of the cool-season grasses. Cultivars are available for much of the area.

Big bluestem, Andropogon gerardi Vitman, is best adapted to deep fertile soils but grows well on a wide range of soils where moisture is adequate or irrigation is used. This species has been used primarily in the Central Great Plains plant growth region. Seed is often available for other areas from harvests of native stands and is usually sold as warm-season grass mixtures. Three cultivars have been released and are available in adequate quantities.

'Kaw' and 'Pawnee' big bluestem are recommended for use in central Nebraska south to the border of Oklahoma, primarily in MLRA's 71 and 73. 'Kaw' is adapted south from Oklahoma.

'Champ' big bluestem is a cultivar developed from an interbreeding population of divergent types of bluestem including big bluestem and sand bluestem. It is recommended for use from Nebraska south into Kansas on favorable sites in MLRA's 64, 65, 66, 67, 71, 72, and 73 and east of this area.

Switchgrass, Panicum virgatum L., is a perennial, tall-growing, weak sod former. It matures earlier than big bluestem and indiangrass. It grows on soils with a wide range of texture, wet acid soils, and brackish marshes. Switchgrass produces excellent wildlife cover and the seed is eaten by song and game birds. Several cultivars have been released and are available in quantity from commercial sources.

'Alamo' switchgrass is a smallseeded type recommended for central and southern Texas and east of

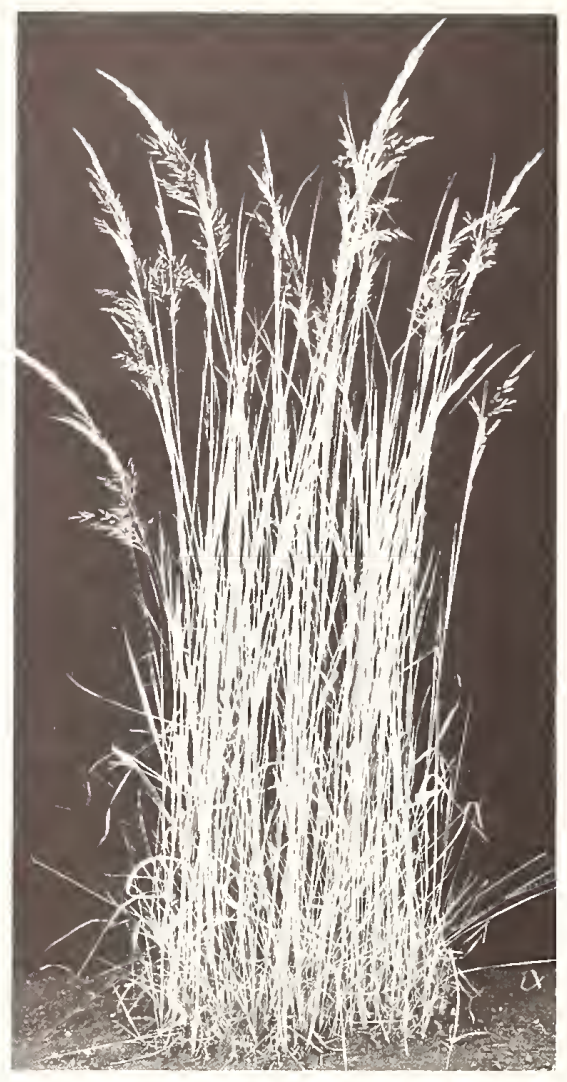

Figure 23. Indiangrass (Sorghastrum nutans).

this area. Its use on mined lands in western Texas is limited to sites with favorable moisture. 'Alamo' is a lowland type selected for late maturity.

'Blackwell' is an upland switchgrass recommended for use primarily in MLRA 73 and eastward in Kansas, Oklahoma, and Nebraska. This cultivar has a wide adaptation and has been used extensively in the East.

'Caddo' switchgrass, a cultivar released in Oklahoma, is adapted to use in the southern part of the Central Great Plains plant growth region in MLRA's 77 and 78.

'Grenville' switchgrass was originally collected at about 5,000 feet $(1,525 \mathrm{~m})$ in a 16 -inch $(40 \mathrm{~cm})$ mean annual precipitation zone of northeastern New Mexico. It is recommended for use in MLRA's 67,70 , and 77 .
'Kanlow' switchgrass is a coarse, upright, lowland bunch grass with excellent wildlife and forage values on moist sites. It is adapted to use in MLRA's 73, 74, and 78, and eastward.

'Nebraska 28' switchgrass is adapted to use in MLRA's 53, 60, $61,63,64,65,66,67,71$, and 72 in South Dakota, Nebraska, and Kansas.

'Pathfinder' switchgrass is an upland type recommended primarily for use in MLRA's 65, 71, and 73.

'Summer' switchgrass is a South Dakota release recommended for use in MLRA's 63, 64, and 66 in South Dakota and adjacent parts of Nebraska and North Dakota.

PM-SD-149 switchgrass was collected originally near Forestburg, South Dakota. It has been distributed for testing and shows promise for use in MLRA's 53B, 53C, 54, and 63.

Indiangrass, Sorghastrum nutans (L.) Nash, is a late-maturing, sodforming, warm-season perennial adapted to deep moist soils with textures from clay to sand (fig. 23). Indiangrass is very palatable. Several cultivars are available.

'Cheyenne' indiangrass is a fineleafed type recommended for use in MLRA's 77 and 78.

'Holt' indiangrass is a fine-leafed type recommended for use in MLRA's 60, 63, 64, 65, 66, 67, 71 , and 72 .

'Llano' indiangrass was collected at about 4,000 feet $(1,220 \mathrm{~m})$ in northeastern New Mexico. It is recommended for use in MLRA's 69, 70,77 , and the southern part of MLRA 67.

'Nebraska 54' indiangrass is recommended for use in MLRA's 71, 72 , and 73 of eastern Nebraska and northeastern Kansas.

'Osage' indiangrass is better adapted to southern areas. It was released by Kansas and is recommended for use in MLRA's 73, 78, and 79 and eastward. 
'Oto' indiangrass, released by the Science and Education Administration and the University of Nebraska, is recommended for use in MLRA's 71,72 , and 73 in Nebraska and adjacent areas.

'Tejas' indiangrass, released by the Texas Research Foundation, was developed from collections in Texas, Oklahoma, and southeastern New Mexico. It is recommended for use in MLRA's 77, 78, and 81.

\section{Major native cool-season grasses for semiarid sites}

All the following species are bunch grasses except western wheatgrass. Four wheatgrasses of the genus Agropyron are of major importance in the Northern Great Plains plant growth region and the northern part of the intermountain region.

Beardless wheatgrass, Agropyron inerme (Scribn. \& Smith) Rydb., is an important bunch grass of the intermountain region from western Montana to central Washington and south into Nevada and Utah. It differs from bluebunch wheatgrass in the absence or near absence of awns. It is less abundant than western wheatgrass.

'Whitmar' beardless wheatgrass is an ecotype domesticated from the Palouse bunch grass prairie. It was selected from an assembly of more than 1,000 collections made throughout the area where the species grows. It tolerates drought and is adapted to the same soils and climate as crested wheatgrass. It performs well throughout the Great Basin Intermontane; the Palouse Prairie, Columbia Basin and Plateau; the Snake River Plain; the Northern and Central Intermountain Desertic Basins; and the Northern Rocky Mountains plant growth regions. It is better adapted to winter-wet and summer-dry climates than to the Northern Great Plains plant growth region where it is

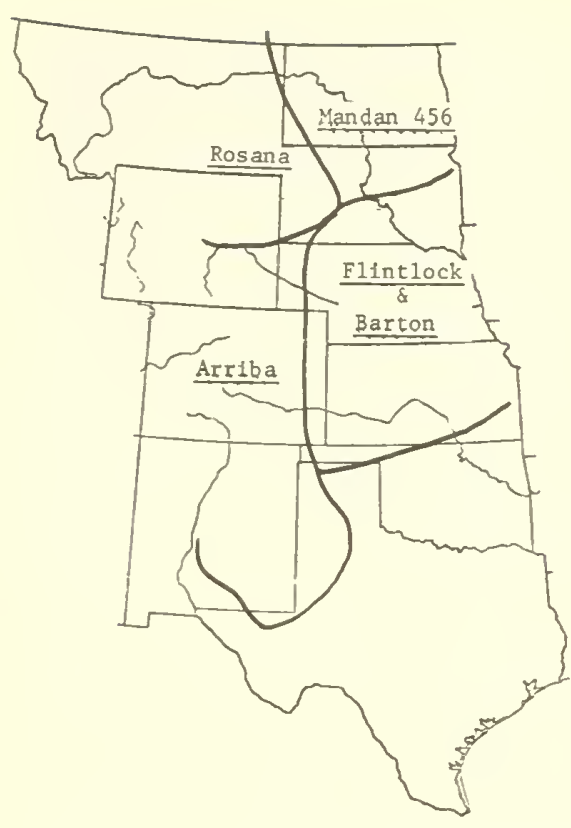

Figure 24. Approximate areas of adaptation of cultivars of western wheatgrass.

outperformed by other species. Seed is available.

Western wheatgrass, Agropyron smithii Rydb., is an aggressive sodforming species most common in the Northern Great Plains plant growth region but growing south into Texas and throughout the intermountain region (fig. 24). In many areas it is the dominant species. It is widely used in range seedings, surface mine reclamation, and critical area stabilization. Western wheatgrass is best adapted to a mean annual precipitation of 14 to 20 inches ( 36 to $50 \mathrm{~cm}$ ) but performs well in the 10 - to 14 -inch ( 25 to $36 \mathrm{~cm}$ ) zone. It is best adapted to soils that are silt or clay but performs satisfactorily on sandy soils. It tolerates soils that are weakly basic to strongly saline. Western wheatgrass ecotypes vary in forage and seed production. color, coarseness, and other characteristics. It is the most important and most successfully established species in the Northern Great Plains plant growth region. Other wheatgrasses and other species of grasses are better adapted in areas with predominantly winter-wet and summer-dry climates. Western wheatgrass is well adapted to cultural management for seed production. Several cultivars have been developed and are available commercially.

'Arriba' western wheatgrass, selected from a collection made in Colorado, is adapted to use in eastern New Mexico and Colorado in MLRA's 34, 39, 48, 49, 67, 69,70 , and 77 .

'Barton' western wheatgrass, developed from a collection in Kansas, is adapted to use in Kansas and Nebraska and adjacent areas in MLRA's 60, 63, 64, 65, 66, 67, 71,72 , and 73 .

'Rosana' western wheatgrass, a selection from Rosebud County, Montana, is adapted to use in Montana, Wyoming, and the western Dakotas in MLRA's 34, 43, 44, 46, $52,53 \mathrm{~A}, 53 \mathrm{~B}, 54,58,60,61$, and 63 (fig. 25).

'Flintlock' western wheatgrass is recommended for use in Nebraska and south-central South Dakota in MLRA's 60, 63, 64, 65, 66, 67, 71,72 , and 73 .

'Mandan 456' western wheatgrass is available for testing in limited quantities. It has potential for use in the western and central Dakotas and Montana in MLRA's 53A. 53B, $54,58 \mathrm{C}, 58 \mathrm{D}, 60,61$, and 63 .

Bluebunch wheatgrass, $\mathrm{Agro}$ pyron spicatum (Pursh) Scribn. and Smith, is an important bunch grass of the intermountain region, the Northern and Central Rocky Mountains plant growth regions and parts of the Northern Great Plains plant growth region. It is more abundant and more widely distributed than beardless wheatgrass. Seed is generally available in limited quantities from native harvests and is a common constituent of range seeding mixtures. This species shows promise for inclusion in mixtures on mined land plantings. 
Slender wheatgrass, Agropyron trachycaulum (Link) Malte, is an important cool-season bunch grass of the Northern Great Plains and the Northern Rocky Mountains plant growth regions and the northern part of the intermountain region. It is seldom found in pure stands. Generally it is used as a fast-growing species in mixtures. Slender wheatgrass tolerates alkali and is useful as a short-lived species in reclamation plantings and range seedings.

'Primar' slender wheatgrass is a selection developed by SCS from a collection made by the Forest Service near Beebe, Montana. It is adapted to use in sweetclover-grass mixtures for pasture, hay, and green manure. It is generally used as a short-lived plant in dryland pastures and as a fast-growing species in range seeding mixtures. It is recommended for use where the species is adapted in areas with a minimum mean annual precipitation of 14 inches $(36 \mathrm{~cm})$.

'Revenue' slender wheatgrass is a cultivar developed in Canada that is well suited to saline soils and in short rotations.

\section{Other cool-season grasses for semiarid sites}

\section{Basin wildrye, Elymus cinereus}

Scribn. \& Merr., is a cool-season bunch grass that tolerates salt and alkali. It is a tall, coarse, long-lived species that is palatable before heading. It is valuable for range seedings on adapted sites and for reclamation plantings, and it provides excellent cover for upland game birds.

Though native to the western part of the Northern Great Plains plant growth region, it is more abundant in the valleys of the Northern Rocky Mountains plant growth region and the northern part of the intermountain area. It develops early in the spring but stands are depleted by overgrazing or frequent cutting for hay. It is better adapted to the winter-wet and summer-dry climate

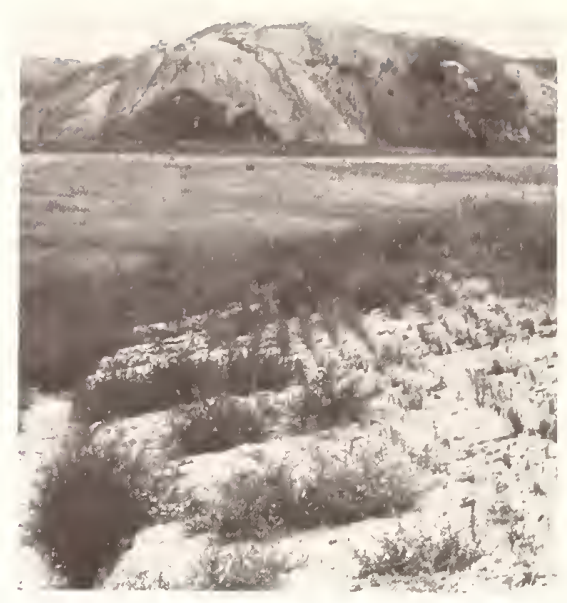

Figure 25. 'Rosana' western wheatgrass establishes well on mine spoils.

than to areas with summer precipitation. If seed production plantings are irrigated, the plants must be allowed to go dormant after harvest or the stands are weakened. Basin wildrye has considerable ecotypic variation in coarseness, growth form, color, yield, and rate of seed germination. Several selections have been distributed for testing.

Big bluegrass, Poa ampla Merr, is one of several native bluegrasses of the northern intermountain area. It is associated with the sagebrush and Palouse Prairie climax vegetation. Hafenrichter, et al. (1968) report that big bluegrass begins growth very early in the spring. Upland game birds, especially pheasant, choose fields of big bluegrass for nesting sites because the bluegrass has more early spring growth than any dryland grass of the area and the basal leaves provide good shade. It has been successfully seeded in areas with as little as 12 inches $(30 \mathrm{~cm})$ mean annual precipitation.

'Sherman' big bluegrass is the only released cultivar of big bluegrass. It has been used successfully for reseeding burned-over forest lands at 2,000 to 6,000 feet ( 610 to $1,830 \mathrm{~m}$ ) in the pine zones of the West.
Canby bluegrass, Poa canbyi (Scribn.) Piper, is a perennial, coolseason bunch grass of the Northern Great Plains plant growth region and the intermountain area. Canby bluegrass is most common as an understory grass on shallow soils in the sagebrush and wheatgrass rangelands of the area. It begins growing early in spring and becomes dormant early in summer. It is useful in controlling erosion because volunteer plants fill the spaces between the larger bunch grasses (Hafenrichter, et al. 1968) Canby is a long-lived species in range seedings. Selections are being evaluated in the area of adaptation.

Needleandthread, Stipa comata Trin \& Rupr., is a cool-season, native bunch grass widely distributed over most of the West. It tolerates drought very well and is common on dry, sandy, or gravelly sites in areas with mean annual precipitation of less than 10 inches $(25 \mathrm{~cm})$ to 16 inches $(40 \mathrm{~cm})$. Needleandthread provides fair to good forage early in the season and after seeds drop. Sharply pointed seeds with long, barbed awns may cause physical injury, especially to sheep. This species is needed for reclamation plantings on droughty sites but it has always been given a low priority because the long awns make seed harvesting and processing difficult. Seed is seldom available from native harvests.

Green needlegrass, Stipa viridula Trin., is a native cool-season bunch grass of the Northern Great Plains plant growth region south into Colorado in the Central Great Plains plant growth region. It is adapted for seeding on a wide range of soil textures but is more abundant on clayey and clay soils. Green needlegrass is most common in areas with mean annual precipitation of 15 inches $(38 \mathrm{~cm})$ or more but grows in areas receiving as little as 10 inches $(25 \mathrm{~cm})$. It has been used extensively in the Northern Great 
Plains plant growth region in range seeding mixtures and on many mined-land reclamation plantings. Seed is available from native harvests and released cultivars. The cultivars developed in North Dakota have performed well over the area of adaptation of the species even when used in Colorado. The movement south has apparently been compensated for by the increase in elevation.

'Green Stipagrass' is superior to common green needlegrass in forage and seed yields and in seedling vigor and regrowth characteristics. It is adapted to the area where the species is common.

'Lodorm' green needlegrass is a more recent release selected for low seed dormancy. It is morphologically indistinguishable from 'Green Stipagrass' and is adapated to the same area.

\section{Native cool-season grasses for mesic sites}

These species occupy distinctly different geographical areas and ecological sites.

Mountain brome, Bromus marginatus Nees, is a cool-season native bunch grass of the Northern and Central Rocky Mountains plant growth regions and the northern part of the intermountain region. Mountain brome is a short-lived species with good seedling vigor. It has been used in mixtures with sweetclover or red clover for pasture or green manure in short rotations. It can also be used to stabilize road cuts and fills or mined lands where rapidly developing seedings are needed. Mountain brome is best adapted to areas with mean annual precipitation of 18 inches $(46 \mathrm{~cm})$ or more.

'Bromar' mountain brome is a superior selection recommended for the area in which mountain brome grows naturally.

Tufted hairgrass, Deschampsia caespitosa (L.) Beauv., is a peren- nial native bunch grass that grows from Greenland to Alaska, south in the eastern United States to North Carolina, and west to Arizona, New Mexico, and California. It is a large, leafy, and palatable grass that usually grows on wet or damp sites at 7,000 to 13,000 feet $(2,135$ to $3,965 \mathrm{~m}$ ) and occasionally down to 5,000 feet $(1,525 \mathrm{~m})$. Although tufted hairgrass is typically associated with mesic meadows, the Forest Service has evaluated ecotypes that have been outstanding on dry, windblown, disturbed sites at high elevations. Tufted hairgrass is not available commercially.

Arizona fescue, Festuca arizonica Vasey, is a native, cool-season, perennial bunch grass. It is commonly found on dry, shallow, clay loam soils but also grows on loams and sandy to gravelly soils. It is mainly associated with ponderosa pine at elevations of 6,000 to 10,000 feet $(1,830$ to $3,050 \mathrm{~m})$ from Colorado to Texas and west to Nevada. The extensive fibrous root system makes this a valuable plant for soil stabilization. It can withstand extended dry periods.

'Redondo' Arizona fescue is the only named cultivar of this species. It was originally collected west of Los Alamos, New Mexico, and is adapted to the natural range of the species. It is useful for revegetating rangelands and stabilizing soil where the vegetation has been greatly reduced or destroyed by construction activities, surface mining, overgrazing, brush control. or fires.

This grass is palatable to all classes of livestock.

Idaho fescue, Festuca idahoensis Elmer, is a cool-season, native bunch grass found from Washington and Montana south to central California and Colorado. It is a valuable range grass, is palatable in spring, cures well on the stem, and makes good fall forage. Idaho fescue is a favorite food of big game. It is a highly variable species. The main deterrent to its use is poor seed production. Idaho fescue is best adapted to areas with mean annual precipitation of 16 inches $(40 \mathrm{~cm})$ or more but grows on north slopes in areas with about 12 inches $(30 \mathrm{~cm})$.

Thurber fescue, Festuca thurberi Vasey, is an attractive, cool-season bunch grass of the Central Rocky Mountains plant growth region. It grows mainly on dry slopes and rocky hills at 6,500 to 12,000 feet (1.985 to $3.660 \mathrm{~m}$ ). Thurber fescue collections are being evaluated and show promise.

Reed canarygrass, Phalaris arundinacea L., is a tall, cool-season, sod-forming grass that is distributed in northern regions. It is well adapted to poorly drained soils subject to flooding but can be grown on upland soils if adequate precipitation or irrigation is available. It tolerates salt and alkali fairly well. The use of reed canarygrass on mined lands is limited to those areas that are wet or receive additional moisture. It is used for forage and for erosion control in wet areas. Reed canarygrass has become a pest in irrigation ditches. Seed of this species does not store well and only newly tested seed should be used. Seed of many domesticated cultivars is available.

\section{Introduced grasses for forage}

Introduced species of grasses play a prominent role in forage and conservation plantings throughout the West. The warm-season species are limited to the warm climates and none are available for the Northern Great Plains plant growth region. Introduced cool-season species are available for most areas. Most of the commonly used introduced species have broader areas of adaptation to soils and climates than the native species and require higher levels of management to maintain stands and production. 


\section{Introduced warm-season grasses for semiarid sites}

Five species of lovegrasses, genus Eragrostis, are the only introduced warm-season grasses currently available for semiarid areas. Their use is restricted to warm climates.

Atherstone lovegrass, Eragrostis atherstonei Stapf, is a warm-season perennial that includes both bunch grass and stoloniferous forms. It is widely distributed from South Africa to south tropical Africa. Accession P-15608, received from South Africa via Australia, has been distributed for field testing. It is a large vigorous bunch grass that is reported to have good seedling vigor and cold hardiness and to be larger and more productive than Lehmann and weeping lovegrass. It is less palatable than Lehmann lovegrass. Atherstone lovegrass is adapted to the Southern Plateaus and Southwestern Desert plant growth regions.

Boer lovegrass, Eragrostis chloromelas Steud., is a warm-season bunch grass introduced from South Africa. It is adapted to warm semiarid areas of the Southern Rocky Mountains, and Southern Plateaus plant growth regions. Boer lovegrass is palatable and drought resistant. 'A-84' Boer lovegrass is the only cultivar released.

Weeping lovegrass, Eragrostis curvula (Schrad.) Nees, is a warmseason bunch grass introduced from Africa. It is used for erosion control and pasture throughout much of the South. It is adapted to the Southern Plains, Southern Rocky Mountains, and Southern Plateaus plant growth regions and to central California.

'Catalina' weeping lovegrass was selected for good stand establishment in Arizona. It is recommended for seedings at elevations below 4,600 feet $(1,403 \mathrm{~m})$ in MLRA's 40 and 41 where the minimum mean annual precipitation is at least 12 inches $(30 \mathrm{~cm})$.

'Ermelo' weeping lovegrass is a comparatively leafy cultivar recom- mended for use in southern Oklahoma and adjacent Texas in MLRA's 77 and 78.

'Morpa' weeping lovegrass was selected for superior acceptability from winter-hardy plants in Oklahoma. It is recommended for use in MLRA's 75, 76, 77, 78, and 79.

Lehmann lovegrass, Eragrostis lehmanniana Nees, is a warmseason, slightly spreading grass introduced from South Africa. Generally it tolerates cold less well than Boer and weeping lovegrass. Lehmann lovegrass is adapted to the Southern Plains, Southern Plateaus, and Southwestern Desert plant growth regions. University of Arizona research has shown that Lehmann lovegrass produces more forage with less water than any other known forage species.

'A-68' Lehmann lovegrass was released in 1950 as a selection that tolerates drought.

'Puhumima' Lehmann lovegrass was released in 1976. It has superior forage yield, and seedlings tolerate drought very well. It is an excellent seed producer and exhibits good reseeding characteristics under natural environments. It is adapted for use in semiarid environments at elevations below 4,500 feet $(1,370$ $\mathrm{m})$ that have a mean annual precipitation of at least 12 inches $(30 \mathrm{~cm})$ in MLRA's 40, 41, and 42.

'Kuivata' Lehmann lovegrass, also a 1976 release, was selected for seedling drought tolerance, plant survival, forage production, and reseeding characteristics under natural conditions. It is adapted for use in semiarid environments at elevations below 4,500 feet $(1,370$ $\mathrm{m}$ ) in MLRA's 40, 41, and 42 where there is mean annual precipitation of at least 10 inches $(25 \mathrm{~cm})$.

Wilman lovegrass, Eragrostis superba Peyr., is a warm-season bunch grass introduced from South Africa. It is a comparatively palatable lovegrass adapted to much the same area as Lehmann lovegrass. It starts growth later than Lehmann lovegrass and the seed does not ripen as uniformly as that of weeping lovegrass.

'Palar' Wilman lovegrass is adapted to use in desert grasslands below 4,500 feet $(1,370 \mathrm{~m})$ in MLRA's 40, 41, and 42 where the mean annual precipitation is 12 to 16 inches ( 30 to $40 \mathrm{~cm}$ ). It is moderately well adapted to the drier areas where shrubs grow and where precipitation ranges from 10 to 12 inches $(25$ to $30 \mathrm{~cm}$ ).

\section{Introduced cool-season grasses for arid and semiarid sites}

The following three grasses (crested wheatgrass, standard crested wheatgrass, and Siberian wheatgrass) are similar cool-season bunch grasses introduced from Siberia. They are used for hay, pasture, and erosion control plantings primarily in the Northern Great Plains plant growth region, but they are important for range seeding in the intermountain region westward to the Cascade-Sierra Nevada plant growth region and south to northern Arizona and New Mexico. All are long-lived, drought-resistant species. They are easily established and start growth early in spring. In favorable seasons they make good fall regrowth. None tolerate prolonged flooding. They are adapted to the 9- to 15 -inch ( 23 to $38 \mathrm{~cm}$ ) mean annual precipitation zone. Several cultivars have been released and seed is available in quantity.

Crested wheatgrass, Agropyron cristatum (L.) Gaertn. 'Fairway' crested wheatgrass is shorter, denser, finer stemmed, and less productive than other cultivars of this group of species. It is better suited to dryland lawns and general-purpose turf. 'Fairway' is a licensed cultivar in Canada. The term "Fairway" is often used in the United States as the common name of all sources of Agropyron cristatum.

'Ruff' crested wheatgrass is a forage cultivar developed from seven 
commercial lots of 'Fairway' crested wheatgrass. It owes its sod-forming characteristics to its adaptation to self seeding and to its broad-bunch plants. 'Ruff' is recommended as a short-season forage crop in the areas of low rainfall in the central plains latitudes. Its self-seeding, sod-forming characteristics suggest its use for dryland turf and cover on disturbed areas.

\section{Standard crested wheatgrass,} Agropyron desertorum (Fisch.) Schult. 'Nordan' standard crested wheatgrass is the standard to which all other perennial grasses and cultivars in this group of standard crested wheatgrasses must be compared. It has been widely used for many years because of its outstanding seedling vigor, excellent seed quality, and forage yield.

'Summit' standard crested wheatgrass was released in Canada and is similar to other standard crested wheatgrasses.

Siberian wheatgrass, Agropyron sibiricum (Willd.) Beauv. 'P-27' Siberian wheatgrass is similar to standard crested wheatgrass. It differs in having narrow awnless seed heads and appears to remain green about 2 weeks longer in the spring. It is well adapted to sandy, droughty soils.

Intermediate wheatgrass, Agropyron intermedium (Host) Beauv., is a cool-season grass introduced from the U.S.S.R. From North Dakota to Washington and south to Colorado and northern Kansas it is used for pasture and hay. Intermediate wheatgrass is a weak sod former adapted to well-drained soils where the mean annual precipitation is a minimum of 14 inches $(36 \mathrm{~cm})$. It is well adapted to short-season irrigated land that is not saline or alkaline. Its moisture requirements are considered to be intermediate between those of smooth brome and pubescent wheatgrass. It has excellent seedling vigor and stand establishment. Seed is available for several cultivars of intermediate wheatgrass.

'Amur' intermediate wheatgrass is a taller, coarser type than other intermediate wheatgrass cultivars and is uniformly gray-green. It is the most commonly used cultivar in the southern part of the Northern Great Plains, in the Central Great Plains, and in the Central and Southern Rocky Mountains plant growth regions. It develops more rapidly than 'Greenar.'

'Chief' is a grayish-green intermediate wheatgrass released by the Canada Department of Agriculture and widely used in Canada. It has also been used in the Northern Great Plains plant growth region.

'Greenar' intermediate wheatgrass is a dark green, moderately rapid sod-forming cultivar. It is widely adapted but has been most commonly used in the northern parts of the mountain and intermountain areas.

'Oahe' intermediate wheatgrass is a tall, coarse, blue-green type that is a rapid sod former. It has been used most extensively in the Dakotas, eastern Wyoming, and eastern Montana.

'Slate' intermediate wheatgrass is a slate-green cultivar that is strongly spreading and erect at maturity. It is used in the southern part of the Northern Great Plains and the Central Great Plains plant growth regions.

'Tegmar' is a dwarf strain of intermediate wheatgrass growing about one-half the height of other cultivars. It has excellent seedling vigor and develops an excellent sod. The shorter growth and vigorous habit make it suitable for use as an erosion-control plant. 'Tegmar' has been especially useful in waterways.

Pubescent wheatgrass, A gropyron tricophorum (Link.) Richt., is a long-lived, drought-tolerant, sodforming species introduced from Eurasia. It is similar to intermediate wheatgrass but tolerates drought better. It is adapted to the Northern Great Plains plant growth region and the intermountain areas where the mean annual precipitation is 12 inches $(30 \mathrm{~cm}$ ) or more below 3,500 feet $(1.068 \mathrm{~m})$. At higher elevations it performs well in areas with mean annual precipitation of 10 inches $(25 \mathrm{~cm})$. It is adapted to a wide range of soil textures from sand to clay. Pubescent wheatgrass forms a sod more rapidly than intermediate wheatgrass and is better adapted to lower fertility, higher elevations, and more alkaline sites.

'Topar' is the most widely used pubescent wheatgrass in the intermountain area. It forms a dense sod.

'Luna' pubescent wheatgrass is a variety with wide, lax, dark green leaves that has performed well from the Central Great Plains through the Northern Great Plains, Central and Northern Rocky Mountains plant growth regions, and the California Sierra Nevada.

'Mandan-759' pubescent wheatgrass, an informal release, has excellent seedling vigor and production in the Northern Great Plains plant growth region. It spreads rapidly. Plants are both blue and green. Some plants intergrade taxonomically into intermediate wheatgrass.

'Greenleaf' pubescent wheatgrass is a Canadian release used in Canada and the Northern Great Plains plant growth region. It is similar to 'Mandan-759' in vigor, production, and hardiness.

Russian wildrye, Elymus junceus Fisch., is a cool-season bunch grass introduced from the U.S.S.R. It is used primarily for pasture in the northern parts of the Great Plains and in the western intermountain area. It is very palatable and has an exceptionally long season of use. It is more difficult to establish than crested. intermediate, or pubescent wheatgrasses. Seed of common Russian wildrye and of the cultivars is available.

'Mayak' and 'Sawki' Russian 
wildrye are cultivars released by the Canada Department of Agriculture.

'Vinall' Russian wildrye was selected because its seed production is less erratic and it produces a greater amount of seed. Lack of these characteristics had been a major deterrent to the use of this species.

Three annual grasses used primarily in the Mediterranean climate of California are also included in this group of introducued coolseason grasses for arid and semiarid sites.

Soft chess, Bromus mollis L., is a cool-season annual bunch grass introduced from Europe (fig. 26). It is widely distributed and is an important forage species in the annual ranges of California.

'Blando' brome, or soft chess, is an improved winter-growing, selfseeding annual grass. It is used primarily for converting grain land to rangeland on sites where perennial grasses are unsuited and for reseeding brush burns where an annual grass is used alone or in combination with perennials. 'Blando' brome is adapted to the winter annual range of California, which includes the Sierra foothills; the range area bordering the Sacramento, San Joaquin, and Salinas Valleys; and the high mountain chaparral ranges of southern California.

California brome, Bromus carinatus Hook. and Arn., is a cool-season, short-lived bunch grass of the intermountain and Pacific Coast regions. It is used for grazing and erosion control. One cultivar is available for use in California.

'Cucamonga' California brome is an early maturing, self-seeding annual grass that develops rapidly. It is most important as a selfperpetuating winter cover crop in orchards and vineyards. 'Cucamonga' California brome is useful as a quick cover on disturbed areas. Its value for forage is limited by its short green feed period. It is best

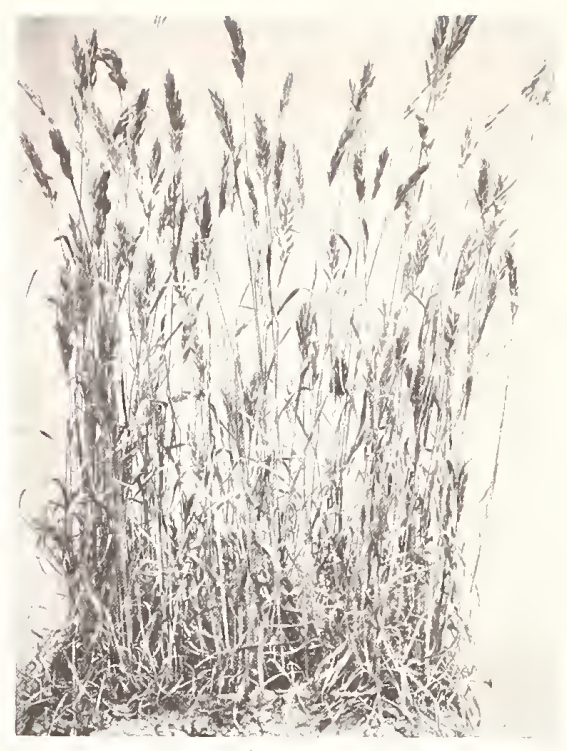

Figure 26. Soft chess (Bromus mollis).

adapted to coarse- to mediumtextured soils with a $\mathrm{pH}$ range of 5.5 to 8.0 where mean annual precipitation is 8 inches $(20 \mathrm{~cm})$ or more.

Swiss ryegrass, Lolium rigidum Gaud., is an introduced annual bunch grass. 'Wimmera 62' ryegrass is a superior annual ryegrass for use in short rotations with barley in the lower rainfall areas of California. It is a fast-growing winter annual. It outperforms domestic ryegrass as a stabilizer on disturbed areas. It does well on soils ranging from coarse to fine texture but gives out after 3 years unless adequately fertilized. It has the same $\mathrm{pH}$ tolerance as 'Cucamonga' brome. 'Wimmera 62' has no advantage over domestic ryegrass in the coastal fog belt or on soils of high fertility where the mean annual precipitation is 12 inches $(30 \mathrm{~cm})$ or more.

\section{Introduced warm-season grasses for mesic sites}

Of the following seven introduced warm-season grasses for mesic sites, none is available for the Northern Great Plains plant growth region, though most can be used in the southern half of the Central Great Plains plant growth region.

Caucasian bluestem, Andropogon caucasicus Trin. (Bothriochloa caucasica (Trin.) Hubb.) is an introduced warm-season bunch grass from the U.S.S.R. It is used for hay and pasture in the Central Great Plains and Southern Plains plant growth regions and east of these areas. Caucasian bluestem is an informal release that is best adapted to central Kansas, western Oklahoma, central Texas, and east of these areas where the mean annual precipitation is 18 inches $(46 \mathrm{~cm})$ or more. It performs best on medium- to fine-textured soils but will grow on sandy soil. It is used in forage seedings and soil stabilization plantings. It is less palatable than the native bluestems.

Yellow bluestem, Andropogon ischaemum L. (Bothriochloa ischaemum Keng.), is a warm-season, semiprostrate bunch grass from U.S.S.R., China, Turkey, and India. It is used primarily for pasture in Texas and southwestern Oklahoma where the mean annual precipitation is 16 inches $(40 \mathrm{~cm})$ or more. Seed of three cultivars is available.

'El Kan' is a winter-hardy strain of yellow bluestem that has been hardy in Kansas but has not been used extensively because other species are generally more productive.

'King Ranch' (KR) yellow bluestem is able to withstand winter temperatures as far north as central Oklahoma. It tolerates drought and is best adapted to range seedings on clay soils and rocky limestone hills.

'Plains' yellow bluestem is winter hardy in Oklahoma and more resistant to foliar diseases than 'King Ranch' bluestem. It is less productive than 'Caucasian' bluestem but is superior in animal acceptance.

Buffelgrass, Cenchrus ciliaris L., is a warm-season bunch grass introduced from South Africa. It is used for pasture in Texas in the Southern Plains plant growth region and to a limited extent in parts of the Gulf 
Coast states. Buffelgrass has good seedling vigor, is drought resistant and nutritious, and withstands fairly heavy grazing. Buffelgrass generally tolerates cold south of a line from San Antonio to Uvalde in south Texas.

'Blue' buffelgrass was selected for its early spring growth recovery, vigorous summer growth, rapid spread by short rhizomes, and tolerance to light frost. It has blue foliage and a tan inflorescence. 'Blue' buffelgrass is best adapted to clay soils in Texas eastward from Sonora and south of Waco. It is a relatively low seed producer.

'Higgins' buffelgrass has green foliage, brownish-wine inflorescence, and a rhizomatous root system. It is a good seed producer. 'Higgins' buffelgrass is adapted to southern Texas.

'Llano' buffelgrass was selected because its tolerance to cold, forage production, and digestibility are superior to that of other buffelgrass cultivars.

'Nueces' buffelgrass is an apomictic $F_{1}$ hybrid. It has improved tolerance to cold, superior forage production, and higher digestibility than other cultivars. 'Nueces' has proven winter hardy 75 miles $(120 \mathrm{~km})$ farther north than other buffelgrass.

' $\mathrm{T}-4464$ ' buffelgrass is an early informal release. It is well adapted to deep sandy soils in Texas where the winter temperatures seldom fall as low as $0^{\circ} \mathrm{F}\left(-18^{\circ} \mathrm{C}\right)$. 'T-4464' is a heavy seed producer. The plants are light green.

\section{Bermudagrass, Cynodon dactylon} (L.) Pers., is a major warm-season, sod-forming grass introduced from Africa in 1751 or earlier. It is used for pasture, hay, lawns, turf, and erosion control. It is best adapted to fertile soils in the humid South but is used in the Southwest on moist sites or irrigated land. Many cultivars are available, some as seedpropagated cultivars and others from vegetative material. Use of bermudagrass on mine spoils is limited.

Blue panicum or panicgrass, Panicum antidotale Retz., is a warmseason sod-forming grass native to India. It is important in parts of the Southwest for dryland and irrigate pastures and for erosion control. It is not winter hardy. Blue panicgrass grows best on fertile, well-drained soils.

'A-130' is a blue panicgrass widely used in Texas and the southern states.

' $\mathrm{T}-15327$ blue panicgrass is a selection from year-old seedlings that survived $-18^{\circ} \mathrm{F}\left(-28^{\circ} \mathrm{C}\right)$ in a dryland planting. It is a heavy seed producer and tolerates cold better than common blue panicum.

\section{Kleingrass, Panicum coloratum} L., is an introduced warm-season grass from Africa. It is used primarily for hay and pasture in Texas and the Southwest. Kleingrass is reported to be causing photosensitivity problems in sheep in area of San Angelo, Texas. So far, Kleingrass has not caused problems in cattle or in sheep in other areas of Texas. Investigations of this problem should be continued. One cultivar, 'Selection 75' has been released.

Natal redtop, Rhynchelytrum roseum (Nees) Stapf. and Hubb., is a short-lived perennial bunch grass adapted to sandy prairies, open fields, and waste places in Texas, Arizona, and southern California. At times it is an annual. It is an introduction from South Africa that has become naturalized in some areas of the Southwest. It is rarely cultivated, but shows promise for use on disturbed areas in the Southern Plains and Southwestern Desert plant growth regions on favorable moisture sites. It is some times used as an ornamental plant.

\section{Introduced cool-season grasses for mesic sites}

This group of plants includes the most common and widely used intro- duced forage species. Most of them are limited to use on mined lands, favorable moisture sites, or areas being reclaimed for irrigated pasture.

Creeping meadlow foxtail, Alopecurus arundinaceus Poir., and meadow foxtail, A. pratensis L., are perennial cool-season species introduced from Europe. They are used for hay and pasture and for erosion control on wet sites in the North. They are productive, palatable plants with high moisture and fertility requirements. Creeping meadow foxtail has strong rhizomes and is well adapted to wetland pastures and mountain meadows. The seeds are black at maturity. Stroh, et al. (1978) reported on this species and noted that creeping meadow foxtail has a wider range of adaptation than meadow foxtail and performs well across the northern states south to the Central Great Plains and Central Rocky Mountains plant growth regions and in the intermountain region. Meadow foxtail is a slightly spreading species with weak rhizomes. It is well adapted to high altitudes and northern latitudes in wetland pastures. The seeds are tan at maturity. The seeds of both species are fluffy and shatter readily. Seed of both species is available.

"Garrison' creeping meadow foxtail has vigorous rhizomes and broad leaves. It is especially adapted to the Northern Great Plains and the Northern and Central Rocky Mountains plant growth regions on wetland sites or irrigated pasture. 'Garrison' is available commercially.

Meadow brome, Bromus biebersteinii Roem. and Schultz, is a coolseason bunch grass native to southwestern Asia. One cultivar has been released and is available.

'Regar' meadow brome establishes seedlings rapidly. It has numerous lax, dominantly basal, mildly pubescent leaves. 'Regar' is an excellent forage plant and has excellent regrowth when summer moisture is 
available. It is used for irrigated pasture or for dryland pasture in northern latitudes that have a minimum mean annual precipitation of 16 inches $(40 \mathrm{~cm})$. 'Regar' is recommended for use in the Northern Great Plains, Northern and Central Rocky Mountains plant growth regions, and the intermountain region.

Smooth brome, Bromus inermis Leyss., is a major cool-season, sodforming grass. It is used for pasture and for erosion control in irrigated areas or areas that have a mean annual precipitation of 15 inches (38 $\mathrm{cm}$ ) or more. Many cultivars are available for use in the Northern and Central Great Plains and the Northern and Central Rocky Mountains plant growth regions, and the northern parts of the intermountain region. Smooth brome tolerates salt fairly well. Local SCS or other agency offices should be consulted about the adapted cultivar to use in each area.

Orchardgrass, Dactylis glomerata L., is a major cool-season introduced bunch grass used for hay and pasture in the North. In the West its use generally is limited to irrigated plantings in the intermountain areas and to areas of higher rainfall. Orchardgrass is less winter hardy than timothy or smooth brome. Numerous cultivars are available. Local agency offices should be consulted for the cultivar best adapted to an area, site, and use. Orchardgrass has only limited use in minedland plantings.

Tall fescue, Festuca arundinacea Schreb., is a major cool-season bunch grass from Europe. It is used for hay, pasture, general-purpose turf, and erosion control in the North. It is irrigated in arid and semiarid regions. It is easily established and grows well on irrigated soils or in areas receiving mean annual precipitation of about 18 inches $(46 \mathrm{~cm})$ or more. It performs test on clayey and clay soils and



Figure 27. Hardinggrass (Phalaris tuberosa stenoptera).

tolerates salt. Palatability is often a problem and it is best seeded alone or with a legume. Tall fescue is widely used in mined-land reclamation plantings in the East because it tolerates a wide $\mathrm{pH}$ range. Its use on mined lands in arid and semiarid areas is limited to favorable moisture sites and to irrigated areas. Several cultivars are available. Selection should be discussed with local agency offices.

Smilograss, Oryzopsis miliacea Benth. and Hook., is a cool-season bunch grass used primarily in range seedings in central and southern California. Smilograss was introduced from the Mediterranean region. It is a drought-resistant perennial with about the same climatic adaptation as hardinggrass, but it performs better on sandy soils. Smilograss is a certified cultivar for use in California.

Koleagrass or perlagrass, Phalaris tuberosa hirtiglumis Batt. and Trab., is a coarse bunch grass introduced from Morocco. It resembles hardinggrass but has round, bulblike enlargements at the base of the culm.

'Perla' koleagrass is a tall, robust, fast-growing bunch grass with short rhizomes. It is easily established and grows well during cold winter months in the Mediterranean climate of California. It is adapted to soils with a restricting layer where the mean annual precipitation is 15 inches $(38 \mathrm{~cm})$ or more.

Hardinggrass, Phalaris tuberosa stenoptera (Hack. Hitchc., is a coolseason, slightly spreading grass from South Africa (fig. 27). It is used for pasture and erosion control in Califfornia and used sparing in other parts of the Southwest. It is best suited to clayey and clay soils in areas having winter rainfall. It is winter active in the Mediterranean climate and adapted to areas of 15 inches $(38 \mathrm{~cm})$ or less rainfall if there is a clay layer in the soil.

"Wintergreen' hardinggrass was selected from three plants that survived an extended drought in central Texas. It is distinguished mainly by summer survival in areas with extended dry periods and high temperatures.

' $\mathrm{P}-14893^{\prime}$ hardinggrass is a selection distributed for testing in California. It exhibited stronger seedling vigor and had finer stems and leaves and more compact growth than common hardinggrass. The shorter stature makes seed harvesting easier.

Upland bluegrass, Poa glaucantha Gaudin, is an introduced coolseason bunch grass used in the North.

'Draylar' upland bluegrass is a cultivar adapted to use as ground cover on soils with low fertility. It is recommended for use in the intermountain region and Northern Rocky Mountains plant growth region in areas having a mean annual precipitation of 16 inches $(40 \mathrm{~cm})$ or more. 


\section{Grasses primarily for soil stabilization}

The grasses included in this grouping may have other values, such as forage production, on adapted sites but their major use is for soil stabilization.

Thickspike wheatgrass, Agropyron dasystachyum (Hook.) Scribn., is a strongly rhizomatous, cool-season perennial grass widely distributed throughout the northern parts of the Great Plains and intermountain area. It closely resembles western wheatgrass, but generally it is greener and is more tolerant to drought. Seedling vigor is excellent and this grass is easily established. Compared to western wheatgrass, thickspike wheatgrass is easier to establish, emerges almost 3 weeks earlier before temperatures are high and while moisture is more reliable, and flowers earlier. Thickspike wheatgrass is adapted to coarser textured soils than is western wheatgrass but total forage production is not as great. Thickspike wheatgrass can be used alone in erosion control plantings or seeded in mixtures for range seedings.

'Critana' thickspike wheatgrass is the only variety named and released at present. It was selected from an ecotype collected in northern Montana and is adapted to Montana, Wyoming, and the western Dakotas. It has been used successfully on mine spoils and in range seedings in Montana and Wyoming. 'Critana' is adapted to a mean annual precipitation zone of 10 to 16 inches ( 25 to $40 \mathrm{~cm}$ ). It forms a tight sod under dryland conditions. In areas with mean annual precipitation greater than 18 inches (46 $\mathrm{cm}$ ) it is outperformed by other species.

Streambank wheatgrass, Agropyron riparium Scribn. \& Smith, is a native sod grass of the Northern Great Plains plant growth region and western intermountain area. It tolerates drought and spreads rapidly to form a good ground cover. It appears early and resembles thickspike wheatgrass. At lower than 3,500 feet $(1,068 \mathrm{~m})$ the minimum mean annual precipitation required for establishment and growth is about 12 inches $(30 \mathrm{~cm})$. Above this elevation streambank wheatgrass has performed well with 9 inches $(23 \mathrm{~cm})$ of precipitation. Streambank wheatgrass is adapted to soils that are moderately alkaline and have sandy to clayey texture.

'Sodar' is the only named and released variety of streambank wheatgrass. It is used widely as a low-growing, low-maintenance cover in the intermountain area. East of the Continental Divide in the Northern Great Plains plant growth region it is outperformed by 'Critana' thickspike wheatgrass. 'Sodar' is useful for roadside seedings, recreation areas, disturbed areas, and other sites where a low-maintenance turf is desired. It produces a relatively smooth cover and is ideal for use on small-plane airfields.

Giantreed, Arundo donax L., is an erect grass that grows as tall as 20 feet $(6 \mathrm{~cm})$. It has stout rhizomes. Giantreed was introduced from Europe and is frequently planted as an ornamental. It has also been used as a barrier to reduce wind erosion. The use of giantreed on mined lands is limited to moist sites in southern areas. It has performed well northward through most of Oklahoma. Plantings are established with vegetative materials.

Red brome, Bromus rubens L., is an annual, cool-season, introduced bunch grass used in the intermountain area and California. Red brome has been used in the same climates as 'Blando' brome for soil stabilization and erosion control. No cultivars are available.

Foxtail fescue, Festuca megalura Nutt., is an aggressive, winter-growing annual grass introduced into California during the Mission period. It is common throughout California below 5,500 feet $(1,680 \mathrm{~m})$, and grows in the intermountain region south to Arizona.

'Zorro' foxtail fescue has an excellent fibrous root system that provides erosion control and improves the tilth of the soil. 'Zorro' has excellent seedling vigor and is superior to 'Blando' brome in establishment on infertile, shallow, or droughty soils where erosion control is critical. It perpetuates itself on highly acid mine spoils ( $\mathrm{pH} 4.5$ ). 'Zorro' tolerates drought. It persists and provides good erosion cover in the California Valleys and Foothills plant growth region where the mean annual precipitation is 12 inches $(25$ to $30 \mathrm{~cm}$ ).

Sheep fescue, Festuca ovina L., is a cool-season bunch grass used in the North for erosion control and as a durable turfgrass on sandy soils (fig. 28). It tolerates cold and drought. It is grazed in the spring but is not widely used for pasture.

'Covar' sheep fescue was developed from a grass introduced from Turkey. It is a dwarf, blue-green, densely tufted cultivar with abundant fine stems. 'Covar' is adapted to dry sites in the mean annual precipitation zone of 8 to 14 inches $(20$ to $36 \mathrm{~cm})$ and at high altitudes in the northern intermountain region and the Northern Rocky Mountains plant growth region, where Idaho fescue grows naturally.

Hard fescue, Festuca ovina duriuscula (L.) Koch, is a cool-season bunch grass from Europe (fig. 29). It is used for erosion control and soil improvement in the Pacific Northwest, the Northern and Central Rocky Mountains plant growth regions, the intermountain region, and on adapted sites in the Northern Great Plains plant growth region. It is adapted to areas receiving mean annual precipitation of approximately 14 inches $(36 \mathrm{~cm})$ or more.

'Durar' hard fescue is a large form of sheep fescue adapted to weldrained soils in the same areas as 




Figure 28. Sheep fescue (Festuca ovina).

hard fescue. It is available in quantity.

Fountaingrass, Pennisetum setaceum (Forsk.) Chiov., is a perennial bunch grass native to South Africa. It has been widely used as an ornamental grass in the Southwest. Fountaingrass has long nodding heads that range from pink to purple. It often reaches a height of 3 feet $(0.9 \mathrm{~m})$. It has escaped from cultivation and can be found growing at lower elevations in Arizona in the mean annual precipitation zone of 7 inches $(18 \mathrm{~cm})$ on medium-textured to fine-textured soils.

Fountaingrass has value for low maintenance landscaping, critical area stabilization, and for use on mined lands and other disturbed areas. The seed is light and difficult to harvest with conventional equipment. Seed and plants are available in limited quantities. Seed should be collected with care. A selection of the same species introduced from India and widely used as an ornamental grass does not produce viable seed.
Common reed, Phragmites communis Trin., is a tall-growing, erect grass with stout creeping rhizomes and stolons. It is widely distributed throughout the world in marshes, streambanks, and wet areas. Common reed is used to reduce wave action on watershed structures. Plantings are made with vegetative material collected from local native stands. The use of common reed in mined land plantings is limited to areas around bodies of water. Considerable work has been done in developing establishment techniques for adapted ecotypes.

'Shoreline' common reed was released for erosion control of shorelines of inland lakes in the southern part of the Central Great Plains plant growth region.

\section{Grasses for sandy sites}

The species in this group have value for forage but their primary use is for vegetating sandy lands.

Sand bluestem. Andropogon hallii Hack., is a warm-season grass with vigorous rhizomes. It is a valuable range grass on deep sandy soils from the Dakotas to Texas and is most important from central Nebraska into eastern Colorado and south into New Mexico and Oklahoma. Several cultivars are available.

'Elida' sand bluestem was developed from a collection from a sand dune area near Elida, New Mexico, at an elevation of 4,300 feet $(1,312 \mathrm{~m})$ in an area with 16 inches $(40 \mathrm{~cm})$ mean annual precipitation. It is a good seed producer. 'Elida' is recommended for use in eastern New Mexico and as far north as eastcentral Colorado in MLRA's 67, 69, 70,72 , and 77 .

'Garden' sand bluestem was originally collected in Garden County in western Nebraska in a 17 -inch $(43 \mathrm{~cm})$ mean annual precipitation zone. It is used for range seedings, soil stabilization, and for seeding areas to provide upland 
game bird cover and nesting sites on sandy loam to sands. 'Garden' sand bluestem is recommended for use in MLRA's 64, 65, 66, 67, 71, 72 , and 73 in Nebraska and adjacent areas in Wyoming, Colorado, and South Dakota.

'Goldstrike' sand bluestem, named for its bright yellow culm internodes and yellow to gold inflorescence, was produced from a synthesis of collections from the northern and western Nebraska sand hills. 'Goldstrike' sand bluestem is recommended for use in MLRA's 63, 64, 65, 66, 67, 71, 72 , and 73 in Nebraska and adjacent areas.

'Woodward' sand bluestem was developed from sources from Woodward, Oklahoma, to Clovis, New Mexico. It is recommended for use in MLRA's 70, 72, and 78.

Prairie sandreed, Calamovilfa longifolia (Hook.) Scribn., is a native, warm-season, sod-forming, tall grass of the Northern and Central Great Plains and the Northern and Central Intermountain Desertic Basins plant growth regions. It tolerates drought and is adapted to mean annual precipitation of less than 10 inches to 20 inches ( 25 to $50 \mathrm{~cm}$ ). It is used for range seedings in mixtures and for soil stabilization on sandy sites.

'Goshen' prairie sandreed was developed from a collection in eastern Wyoming. It is adapted for use in Montana, Wyoming, the western Dakotas, and western Nebraska in MLRA's 32, 34, 52, 53A, 53B, 54, $58 \mathrm{~A}, 58 \mathrm{~B}, 58 \mathrm{C}, 58 \mathrm{D}, 60,61,64$, 65,67 , and 72 .

Mammoth wildrye, Elymus giganteus Vahl., is a cool-season, sodforming grass introduced from the U.S.S.R. It is used for inland sand dune stabilization in the intermountain area. Mammoth wildrye is coarse, tall, and relatively unpalatable. It is established on dunes with vegetative materials. Recent trials with seed have produced excellent stands on mined lands and other disturbed areas where soil blowing is not a problem.

'Volga' mammoth wildrye is used throughout the West and was released as a vegetatively propagated variety. It is a good seed producer.

Indian ricegrass, Oryzopsis hymenoides (Roem. and Schult.) Ricker, is a densely tufted perennial with upright stems. It is widely distributed over the West where it is one of the most drought-enduring native range grasses. The species grows at 2,000 to 10,000 feet ( 610 to $3,050 \mathrm{~m})$. It is most abundant from low semiarid ranges up through the pinyonjuniper zone. It grows on semideserts, sand dunes, sandy plains, canyons, hillsides, foothills, exposed ridges, and dry sandy, rocky, or granulated shale sites. It is one of the first species to become established on disturbed sandy sites.

Indian ricegrass is both attractive and palatable to all classes of livestock, and is one of the most important forage grasses of semiarid ranges. The nutritious forage cures well and has special value on winter ranges. This species has excellent seedling vigor and is easily established. Birds, especially mourning dove and pheasant, and small rodents relish the plump nutritious seeds. There is considerable ecotypic variation in this species and plantings must be made from adapted seed sources.

'Nezpar' Indian ricegrass was selected for its unusually low percentage of hard seeds and excellent seedling vigor. It is recommended for use throughout the intermountain area of the West.

'Paloma' Indian ricegrass was collected in the vicinity of Pueblo, Colorado. It is used for range seeding and soil stabilization in Arizona, Colorado, and New Mexico.

Spike dropseed, Sporobolus contractus Hitchc., is a warm-season, perennial bunch grass similar to sand dropseed. Spike dropseed grows on

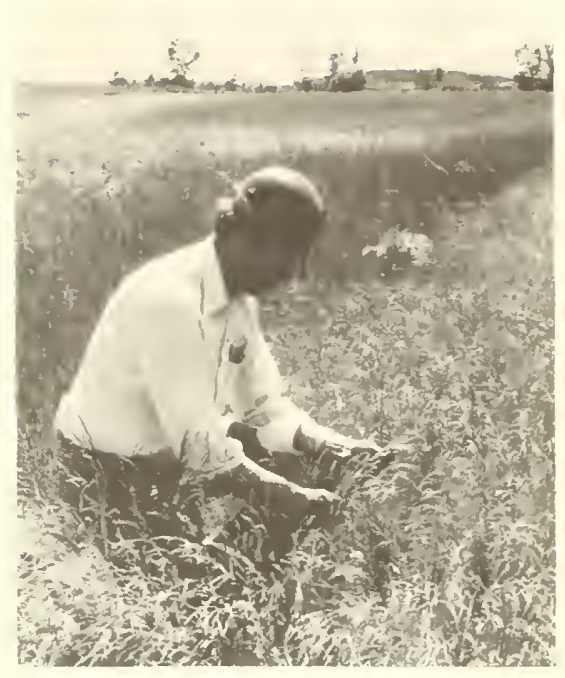

Figure 29. Hard fescue growing on a mine spoil; this grass is adapted throughout much of the West.

mesas, dry bluffs, and sandy soils in the Southern Plains, Central Great Plains, Southern Plateaus, Southern Rocky Mountains, Southwestern Desert plant growth regions, and the southern part of the Great Basin Intermontane plant growth region. It is a prolific seed producer and establishes rapidly on depleted ranges. Cultivars are not available at present.

Sand dropseed, Sporobolus cryptandrus (Torr.) A. Gray, is a widely distributed bunch grass common on sandy sites in western ranges (fig. 30). Though its palatability is low, it provides fair winter forage. Sand dropseed is a prolific seed producer and increases on depleted ranges and on wastelands. Seed is available though no cultivars have been released.

Mesa dropseed, Sporobolus flexuosus (Turb.) Rydb., is a native warm-season bunch grass. It closely resembles sand dropseed and replaces that species for use in MLRA 42 of the Southern Plateaus plant growth region. Mesa dropseed grows from western Texas and southeastern Colorado to Arizona, southern Utah, and southern Nevada, at elevations of 3,000 to 5,500 feet ( 915 to $1,680 \mathrm{~m})$. Mesa dropseed is an 
abundant and important species on sandy soils. It is a short-lived species ( 4 to 5 years) but reseeds readily even in areas with 6 to 7 inches (15 to $18 \mathrm{~cm}$ ) mean annual precipitation. It grows mainly in areas with mean annual precipitation of 12 inches $(30 \mathrm{~cm})$ or less. Mesa dropseed has value for soil stabilization on sandy lands.

Giant dropseed, Sporobolus giganteus Nash, is a large, warmseason native bunch grass. It grows on deep sands to sandy soils from western Oklahoma and western Texas to New Mexico and Arizona. Giant dropseed grows upward rapidly in sand dunes and can be used for dune stabilization. It is most important in the mean annual precipitation zone of 7 to 12 inches $(18$ to $30 \mathrm{~cm}$ ) in the Southwest at 4,500 to 6,000 feet $(1,370$ to 1,830 $\mathrm{m})$. Giant dropseed has been grown commercially for seed.

Twoflower trichloris, Trichloris crinita (Lag.) Parodi., is a native perennial bunch grass of the Southern Plains, Southern Plateaus, and Southwestern Desert plant growth regions. It grows at elevations from 1,000 to 4,000 feet ( 305 to $1,220 \mathrm{~m}$ ) in Texas, New Mexico, and Arizona on dry rocky slopes and sandy soils. It is often found in association with creosotebush at lower elevations. Twoflower trichloris tolerates drought very well and grows in areas with as little as 6 inches $(15 \mathrm{~cm})$ mean and annual precipitation. Twoflower trichloris is valuable in low maintenance landscaping, range seeding, and minedland reclamation. It tolerates salinity. Little work has been done with this species because the seeds are extremely fluffy and difficult to work with. Seed is not available commercially.

\section{Saline-and alkali-tolerant grasses}

These grasses perform well on saline, saline-alkali, and alkali soils where other species are not adapted.



Figure 30. Sand dropseed (Sporobolus cryptandrus).

They are usually planted alone to facilitate grazing management.

Tall wheatgrass, Agropyron elongatum (Host.) Beauv., is a tall, vigorous, stemmy bunch grass (fig. $31)$. It is a late-maturing species, and though it does not appear palatable, it is used successfully if seeded alone. It is an excellent forage producer and is especially useful on irrigated or subirrigated saline soils and on imperfectly drained alkali soils throughout the West. Tall wheatgrass also provides excellent cover for upland game birds. It has excellent seedling vigor and is the most easily established of the species in this group.

Seed of common tall wheatgrass and of several cultivars is available in quantity. Tall wheatgrass is an introduced species from Turkey, other parts of Asia Minor, and the U.S.S.R. The cultivars are difficult to distinguish morphologically. Most have wide ranges of adaptation. Local agencies should be consulted for the particular cultivars recommended.

'Alkar' tall wheatgrass was released in Washington in 1951. It is the most widely used cultivar in the intermountain region and is used extensively in the Northern Great Plains plant growth region.

'Jose' tall wheatgrass was released in New Mexico in 1965. It is somewhat less coarse and earlier maturing than other tall wheatgrass cultivars.

'Largo' tall wheatgrass was released in New Mexico in 1937 as A1876 and later named 'Largo'. It is widely used in Colorado, Utah, Arizona, New Mexico, and California.

'Orbit' tall wheatgrass is a 1966 Canadian release selected for superior winter hardiness in Canada.

'Platte' tall wheatgrass is a 1972 Nebraska release. It was developed from 'Nebraska 98526', a cultivar widely used from 1950 to 1965 , and a strain designated 'Cheyenne' de- 
rived from three generations of selection from volunteer plants in the grass nursery at the Cheyenne, Wyo., Horticultural Field Station.

Inland saltgrass, Distichlis stricta (Torr.) Rydb., also known as desert saltgrass, is a low-growing, dioecious species (separate male and female plants) with extensive creeping rhizomes and stolons. It is a native grass and grows throughout much of the West on subirrigated soils and on sites that are intermittently wet and dry. Inland saltgrass is mainly grazed when it is green. It is an outstanding plant to provide windor water-erosion control cover on adapted sites. Inland saltgrass has been tested extensively. The primary deterrent to its use is poor seed production in the materials assembled so far. Seed is not available.

Beardless wildrye, Elymus triticoides Buckl., is a cool-season, sodforming grass native at low and medium elevations from Montana to Washington and south to west Texas and California. It seldom grows in extensive stands. It is a species most tolerant to salt and alkali, and is adapted to a wide range of soil texture on subirrigated soils. Seed production of most collections has been poor and seed dormancy problems have resulted in poor stand establishment. This species has many attributes and deserves extensive study.

Alkali sacaton, Sporobolus airoides (Torr.) Torr., is a coarse, densely tufted perennial grass native throughout the West. It grows on moderately fine textured saline, saline-alkali, and alkali soils. It is especially abundant on lowland sites that occasionally overflow. It provides excellent leafy ground cover. Although seed is usually obtained from native stands, this species produces excellent seed crops in cultivated irrigated rows and will produce more than 500 pounds of clean seed per acre $(560 \mathrm{~kg} / \mathrm{ha})$. Establishnient has been difficult except where the seed was irrigated frequently. Once established, the plant requires little maintenance. It tolerates drought and performs well in the 12 to 18 inches ( 30 to $46 \mathrm{~cm}$ ) mean annual precipitation zone or in areas of less precipitation where it can be irrigated occasionally. Named and released cultivars are not available at present.

Other species that can be grown on some saline and alkali soils are tall fescue, streambank wheatgrass, western wheatgrass, slender wheatgrass, crested wheatgrass, basin wildrye, and two-flower trichloris. Performance depends on the salts and the amount of water that can be made available. These species are discussed elsewhere in the text under the major use or adaption of each.

\section{Forbs}

Forbs are herbaceous plants other than grasses, sedges, and rushes. Forbs are often referred to as weeds but most are not weeds. Weeds are by definition unwanted or undesirable plants. Forbs are the most numerous group of plants but are seldom dominant and almost always occur in mixtures. They may be annuals, biennials, or perennials. $\mathrm{Na}-$ tive forbs are important to wildlife and livestock, especially sheep. At certain seasons forbs provide a major part of the diet of big game animals and the seeds are often the principal food of upland game and other birds. The introduced forbs include the important forage legumes.

\section{Native forbs}

Several native forbs are available commercially. Efforts have been increased to study and develop these plants for a wide variety of uses. At present the primary use of native forbs is to add diversity to plantings, though they also produce limited livestock forage. Legumes produce limited amounts of nitrogen and should be inoculated with the proper rhizobia. Native forbs are used to develop more attractive areas and more natural ecological conditions. They help to increase the number of species and the populations of both invertebrate and vertebrate forms. Forbs also provide additional cover for erosion control. Some forbs volunteer into openings in grass plantings and provide greater erosion control cover than grasses alone. Such forbs as Maximilian sunflower are vigorous and easily established and only minimal amounts of seed should be included in mixtures. Other less vigorous nonspreading species require greater amounts of seed to become established in competition with grasses and other forbs.

Forbs are important on many disturbed areas, such as roadsides, where they improve the appearance. There are opportunities to use mixtures of species that provide colorful flowers throughout a large part of the growing season. The best guide to species that are compatible with each other and with the grasses is the natural plant community on similar sites in the area. There are numerous ecotypes over the range of each species. Sound ecological principles must be followed in selecting plant materials. A few promising native forbs are discussed in the following paragraphs.

Illinois bundleflower, Desmanthus illinoensis (Michx.) MacMill., is a deep-rooted, warm-season, perennial native legume. It grows 2 to 4 feet $(60$ to $120 \mathrm{~cm})$ tall. Illinois bundle flower is found throughout the prairies and plains. It grows on a wide variety of soils but is most common on moist depressions. It is eaten readily by all classes of livestock and decreases under heavy grazing. Illinois bundleflower produces abundant seed under cultivation and is easily established from seed. In general it is most common in areas with 16 inches $(40 \mathrm{~cm})$ or more mean annual precipitation. 
Several selections have been made, but no released cultivars are available.

Gold poppies, Eschscholzia spp. Cham., are mainly annual forbs characteristic of warm dry climates. There are several species in the West. They generally grow at elevations below 4,000 feet $(1,220 \mathrm{~m})$. The California poppy, E. californica Cham., is the most commonly known. It is a highly variable species that may be an annual or a shortlived perennial. Gold poppies appear to have little forage value and have been suspected to have poisonous characteristics because of the toxic alkaloids some possess. Gold poppies are used as ornamentals and have become naturalized in many areas of the West. They persist only if the site is natural for the species. Gold poppies are most commonly associated with rocky banks, loose gravel, or sandy areas where there is little competition from grasses. Seed is available in limited quantities and has been successfully included in planting mixtures.

Slender gaillardia, Gaillardia pinnatifida Torr., is an attractive native perennial forb of the Central Great Plains, Southern Plains, and Southern Plateaus plant growth regions. It generally grows at 4,000 to 6,500 feet $(1,200$ to $1,983 \mathrm{~m})$. Slender gaillardia has yellow ray flowers tinged with red near the base and reddish-purple disk flowers. It is most common on sandy and rocky sites. Preliminary evaluations of this species indicate it may lend itself to cultivated seed production and be readily established.

Maximilian sunflower, Helianthus maximiliani Schrad., is a herbaceous stout perennial with short rhizomes. It is associated with plant communities of the true and mixed prairies. Maximilian sunflower grows in the Central and Northern Great Plains plant growth regions on deep soils that range from clay loams to sandy loams. It is used in mixtures with

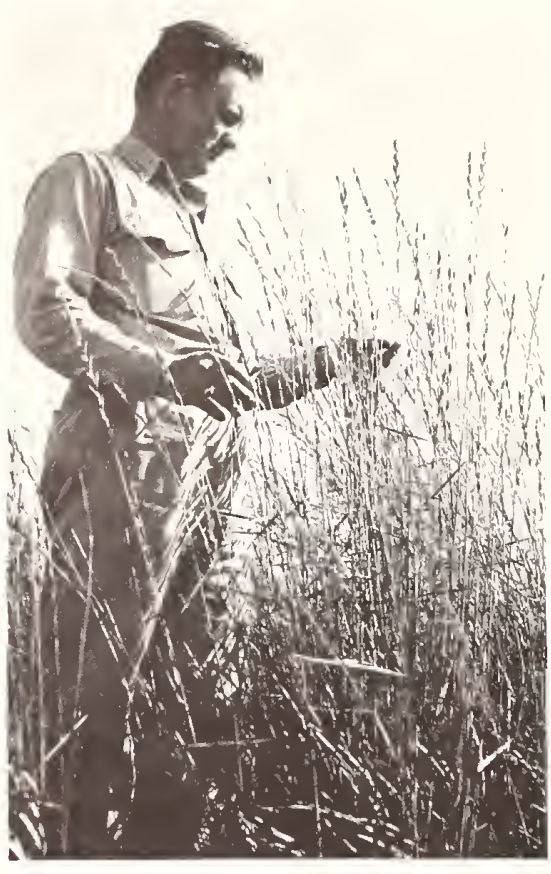

Figure 31. Tall wheatgrass (Agropyron elongatum).

grasses and other forbs to provide greater diversity to plantings. It is palatable to livestock. Seed of the following cultivars is available:

'Prairie Gold' Maximilian sunflower is a cultivar released in 1978 that is adapted to a mean annual precipitation of 14 inches $(36 \mathrm{~cm})$ and more in Kansas, Nebraska, southern South Dakota, northern Oklahoma, and eastern Colordo. It is readily established from seed and competes strongly with native grasses.

'Aztec' Maximilian sunflower, also a 1978 release, is adapted to western Texas, western Oklahoma, and eastward.

Stiff sunflower, Helianthus laetiflorus Pers. (H. rigidus (Cass.) Desf.), is a perennial sunflower of the Central and Northern Great Plains plant growth regions and eastward. It appears to have potential for use in wildlife plantings and to have the necessary seed production and establishment possibilities. The use of stiff sunflower is limited to arid and semiarid areas receiving a minimum of 15 inches $(38 \mathrm{~cm})$ mean annual precipitation.

Bush morningglory, Ipomoea leptophylla Torr., is a perennial shrubby forb with attractive flowers about 3 inches $(8 \mathrm{~cm})$ in diameter. It grows to a height of 2 to 5 feet ( 0.6 to $1.5 \mathrm{~m})$ on dry plains from western South Dakota and Wyoming to northwestern Texas and New Mexico. Bush morningglory is most common on sandy soils and sand dunes. The large tuberous rootstocks store moisture. The plants tolerate drought very well. Bush morningglory is being evaluated for use in soil stabilization plantings. No planting materials are available at present.

Palmer penstemon, Penstemon palmeri A. Gray, is one of the most beautiful species of Penstemon. It is a short-lived perennial with attractive white corollas fringed with pink. Basal leaves remain green throughout the winter. It grows mainly at elevations of 3,500 to 6,500 feet $(1,068$ to $1,983 \mathrm{~m})$ in washes and along roadsides in the sagebrush and pinyon pine zones from Utah and Arizona to California. Palmer penstemon shows promise of providing good cover on eroding sites. Gaming animals browse the plant.

Rocky Mountain penstemon, Penstemon strictus Benth., is an herbaceous, long-lived species with deep blue flowers. It is useful for beautification, soil stabilization, and ornamental plantings. The natural range of Rocky Mountain penstemon is central and nothern New Mexico, Colorado, southern Wyoming, Utah, and eastern Arizona at elevations of 6,000 to 11,000 feet $(1,830$ to 3,355 $\mathrm{m})$. It grows on rocky to sandy loam soils. It is an excellent seed producer under cultivation and has good seedling vigor. It can also be established from sprigs.

'Bandera' Rocky Mountain penstemon has an abundance of dark, shiny, green leaves. The lower leaves form a basal rosete. Some of the 
leaves turn purple, but most remain green throughout the year. 'Bandera' seems to be adapted to the range of the species. Seed is available.

White prairieclover, Petalostemum candidum (Willd.) Michx., is an herbaceous perennial legume with a woody taproot. It grows on a wide range of soils and is native from Saskatchewan to Mississippi, Texas, Arizona, and Mexico. It is adapted to areas receiving a minimum of 14 inches $(36 \mathrm{~m})$ mean annual precipitation. In the West it is most common from 3,500 to 7,000 feet (1,068 to $2,135 \mathrm{~m})$. It is common on plains and in openings in forests and is palatable to all classes of livestock. White prairieclover is an excellent seed producer under cultivation. It shows promise for soil stabilization in mixtures with forbs and grasses.

\section{Purple prairieclover, Petaloste-} mum purpureum (Vent.) Rydb., is an herbaceous perennial legume with a woody taproot. It grows on a wide range of deep soils. It is native to much the same area as white prairieclover but has higher moisture requirements, generally a minimum of 16 inches $(40 \mathrm{~cm})$ mean annual precipitation. Purple prairieclover is an excellent seed producer and is well suited to cultivated seed production. One cultivar has been released.

'Kaneb' purple prairieclover is available for use in mixtures for range seedings, roadside plantings, and soil stabilization plantings. 'Kaneb' has been widely tested. It is adapted to Kansas, Nebraska, eastern Colorado, Oklahoma, and probably a much wider area. 'Kaneb' is winter hardy and has performed well for several years at Bridger, Mont., and Bismarck, N. Dak.

Pitcher sage, Salvia pitcheri Torr., is an herbaceous perennial with simple or branched stems that grows to a height of 2 to 4 feet ( 0.6 to $1.2 \mathrm{~m})$. It has attractive blue flowers.
Pitcher sage shows potential for use in adding diversity to warm-season grass plantings in the northern part of the Central Great Plains plant growth region and the southem part of the Northern Great Plains plant growth region.

'Nekan' pitcher sage has excellent seedling vigor and can be established in mixtures with grasses. Seed is available in quantity.

Annual bushsunflower, Simsia exaristata Gray, is an annual herb native from western Texas to southeastern Arizona in the Southern Plateaus plant growth region. It has attractive yellow flowers. Annual bushsunflower has been used for its wildlife values in range seedings in western Texas. Seed is available only in limited quantities.

American vetch, Vicia americana Muhl., is a trailing or climbing perennial herb. It grows over a wide area of the West on sites with adequate moisture. In the southwestern part of its range American vetch is most common in pine forests at elevations of 5,000 to 10,000 feet $(1,525$ to $3,050 \mathrm{~m})$. It is an excellent forage plant that is palatable to livestock and wildlife. It decreases under grazing and is found on ranges in good condition. Seed is available in limited quantities, but only adapted ecotypes should be used because the species is highly variable.

Orange Zexmenia, Zexmenia hispida H.B.K., is a native perennial forb confined to the Southern Plains plant growth region. Orange zexmenia has been used sparingly as an inclusion for wildlife benefits in range seedings in southern Texas. Seed is available from harvests of native plants.

\section{Introduced forbs}

The introduced forbs are primarily those introduced legumes used for forage production. They produce nitrogen and extend or supplement grazing. Most of these species are limited to irrigated plantings or to sites where irrigation is not needed. Some species are fast growing and provide erosion control and protection for the establishment of long-lived species. The introduced forbs include wide-ranging species adapted to a wide range of soil textures and moisture.

Winter-active species may be able to withstand long dry periods by becoming dormant. Some can reseed and germinate when moisture is available.

Cicer milkvetch, Astragalus cicer L., is a long-lived legume native to Europe. It has attractive yellow flowers and vigorous creeping rhizomes. Cicer milkvetch is eaten by all classes of livestock as either hay or pasture, and also is eaten by antelope, deer, and elk. There has been no history of bloat for this species. Cicer milkvetch tolerates slightly acid to moderately alkaline soils. The optimum moisture range is between 18 and 35 inches ( 46 to $90 \mathrm{~cm}$ ) mean annual precipitation. On mined lands cicer milkvetch is limited to sites with favorable moisture or to areas to be irrigated One cultivar has been released in the United States.

'Lutana' cicer milkvetch is available in quantity. Trial plantings have been made in all western states from Alaska south to Las Cruces, New Mexico, and from the Central Great Plains plant growth region west to the Cascades and Sierras. The range of adaptation is the Northern Great Plains and Rocky Mountain regions. 'Lutana' cicer milkvetch is performing well on mine spoils in Montana in an area with 14 inches $(36 \mathrm{~cm})$ of mean annual precipitation. 'Lutana' is winter hardy and has performed well at elevations of 2,000 to more than 7,000 feet ( 610 to $2,135 \mathrm{~m}$ ) in Montana and Wyoming.

Crownvetch, Coronilla varia $\mathrm{L}$., is a rhizomatous perennial legume that is best adapted to well-drained cal- 
careous soils. It has attractive, longblooming pink flowers. It grows on mildly alkaline to slightly acid soils but not on wet, poorly drained soils. Crownvetch was introduced from Europe. It is used primarily for soil stabilization of roadbanks and mine spoils. It is slow to establish but very persistent. In arid and semiarid areas it is limited to sites with adequate moisture. Planting material of several cultivars is available in quantity. Local agencies should be consulted for the proper cultivar for the site and the land use planned.

Alfileria, Erodium cicutarium (L). L'Her., is an annual of the geranium family. It is a native of Europe and is now naturalized on dry plains, mesas, hillsides, and waste places. It grows at elevations of 100 feet to more than 8,500 feet ( 30 to $2,590 \mathrm{~m}$ ). In favorable seasons it is an abundant and aggressive invader of desert ranges. In the spring it furnishes choice grazing for livestock, although in some situations it has been reported to be poisonous. Alfileria is included here because it is considered an important plant in parts of the West. Seed is available some years in commercial quantities.

Prostrate summercypress, Kochia prostrata (L.) Schrad., is a longlived, perennial half-shrub native to the arid and semiarid regions of Russia, central Europe, and the eastern Mediterranean. Plants are 1 to 3 feet $(30$ to $90 \mathrm{~cm}$ ) tall, develop an extensive root system, and have exceptionally good tolerance to drought. Flowers are solitary or grow in twos or threes in the leaf axils. Plants develop a large crown, and numerous simple stems are iniated each year. Leaves are bluish green with silky pubescent surfaces.

L. E. Francois (1976) indicated that prostrate summercypress is very dependent on day length. His plants stopped growing in the winter (October through March) even though the greenhouse temperatures were kept constant. B. K. Shishkin (1936) described prostrate summercypress as being an exceptionally polymorphic species with various geographic races and ecotypes. One race or ecotype grows on sand or sandy soils, and another grows mainly on saline soils. Prostrate summercypress is eaten readily by sheep, goats, and horses.

Birdsfoot trefoil, Lotus corniculatus L., is an attractive yellowflowered legume. It is used for forage and stabilization plantings. The use of birdsfoot trefoil in reclamation plantings is limited to irrigated areas or sites with adequate moisture. Seed of many cultivars is available in quantity. Local agencies should be consulted for the recommended cultivars for the site and the planned use.

Alfalfa, Medicago sativa L., is a deep-rooted perennial legume introduced from Europe. It is the most important hay and pasture plant in the United States and is also an important wildlife food plant for birds and mammals. Many cultivars are available in quantity. There is a wide variation in the adaptation to soils and moisture of the cultivars and local agencies should be consulted as to the best choice.

White sweetclover, Melilotus alba Desr., and yellow sweetclover, $M$. officinalis (L.) Desr., are important Eurasian biennials. They are used as pasture plants and are important wildlife food plants for birds and mammals. They have excellent seedling vigor and are important as soil improving crops, as short-lived cover or preparatory crops, or for use in mixtures in soil stabilization plantings. The sweetclovers are widely adapted and used throughout the West with the exception of the Southwestern Desert and California Valleys and Foothills plant growth regions. Yellow sweetclover has higher moisture requirements than white sweetclover and is most commonly used in seedings in mountain areas. Seed is available in quantity.

Sainfoin, Onobrychis viciaefolia Scop., is a pink-flowered, long-lived, cool-season, deep-rooted legume native to southern Europe. It is widely used in Europe for hay and pasture. Sainfoin has become locally important as a forage plant in parts of the western Northern Great Plains plant growth region and northern intermountain regions. It does not cause bloat and is especially valuable in areas where bloat is a problem. Sainfoin is adapted to well-drained soils of sandy to loamy texture, and grows best with a mean annual precipitation of 16 inches $(40 \mathrm{~cm})$ or more.

'Eski' and 'Remont' are two sainfoin cultivars available in quantity. 'Eski' was the first cultivar of this species released in the United States. 'Remont' was selected for its superior regrowth characteristics.

The true clovers, genus Trifolium, are common natives of the West, but several European species are important. Some species have become naturalized. The clovers are important soil-enriching forage and wildlife plants. In the Southwest they are found primarily in subalpine meadows and the ponderosa pine areas. Clovers are limited to reclamation plantings on sites with favorable moisture. A few of the commonly used species are discussed.

Strawberry clover, Trifolium fragiferum L., is a European perennial useful in reclaiming moist meadows made alkaline by seepage from irrigation ditches. It may be useful for similar situations on mined lands.

Rose clover, Trifolium hirtum All., is a freely branching, wintergrowing annual legume recently introduced from Turkey. It grows from 3 to 24 inches ( 8 to $60 \mathrm{~cm}$ ) tall. Rose clover is widely adapted to the climate of California below elevations of 3,500 feet $(1,068 \mathrm{~m})$ except 
in the coastal fog belt and areas having less than 10 inches $(25 \mathrm{~cm})$ mean annual precipitation. It is well adapted to well-drained soils. Rose clover does well on strongly acid to moderately alkaline soils but performs best if the $\mathrm{pH}$ ranges between 6 and 7. It is less tolerant to low pH but tolerates drier conditions better than does subterranean clover. Rose clover grows best when fall rains occur while the weather is still relatively warm. It is used primarily for dryland pastures but is also used for cover crops and as a low-growing, low-volume, self-perpetuating legume.

'Wilton' rose clover is an upright cultivar with good seed production. It is the only cultivar of rose clover whose seed is produced in the United States.

'Kondinin' rose clover is a cultivar developed in Australia. It has semierect growth and matures early in the season to midseason.

'Hykon' rose clover is also an Australian cultivar. It matures about 10 days earlier than 'Kondinin'.

Crimson clover, Trifolium incarnatum $\mathrm{L}$., is a winter annual introduced from southern Europe. It is used for winter soil protection, green manure crops, and grazing.

Red clover, Trifolium pratense L., is primarily biennial but under favorable conditions may carry over a third year. It is mainly used in the East but is also used in irrigated areas in the West except in the arid Southwest. It is an important forage crop that also provides excellent wildlife benefits.

\section{White clover, Trifolium repens} L., is a widely naturalized introduction from Eurasia. It is a longlived perennial with creeping branches that frequently root at the nodes. Different cultivars are used for forage, turf, or erosion control. White clover is best adapted to soils with moderately fine to medium texture.

Subterranean clover, Trifolium

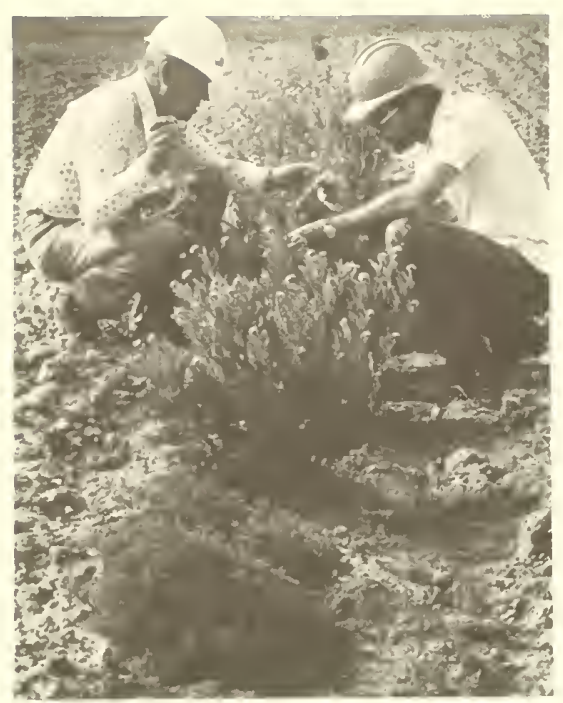

Figure 32. Species of woody shrubs and forbs are tested on reclaimed strip mines in Wyoming. (SEA 0878X935-35A).

subterraneum L., is a self-perpetuating, winter-annual legume introduced from Europe via Australia. It is commonly called subclover because some of its ripening seedheads turn downward and push into the soil. Subterranean clover has creeping stems 2 to 4 feet ( 60 to $120 \mathrm{~cm}$ ) long. It grows best on welldrained, fertile loam soils in areas with mean annual precipitation of 18 to 20 inches or more ( 46 to 50 $\mathrm{cm})$. It is used in the California Valleys and Foothills plant growth region for erosion control, hay, pasture, soil improvement, and seed production. It is difficult to harvest because of the prostrate growth habit. Several cultivars are available.

Woolypod vetch, Vicia dasycarpa Ten., is a self-seeding, cool-season annual legume similar to hairy vetch. It was introduced from Europe. Woolypod vetch is used for range improvement, cover crops, wildlife, soil stabilization, and weed control. It can be seeded alone or in mixtures with 'Blando' brome and 'Wimmera 62 ' or common annual ryegrasses.

'Lana' woolypod vetch performs well on sandy to clayey soils in areas of Mediterranean climate where the mean annual precipitation is 14 inches $(36 \mathrm{~cm})$ or more. It is adapted to use on soils that are moderately acid to moderately alkaline in MLRA's 17, 18, and 31.

Hairy vetch, $V$ icia villosa Roth., is a slender twining annual legume from Europe. It grows on a variety of soils, including clays, and tolerates alkali soils better than most legumes. It is drought resistant. Hairy vetch has weak stems and is usually planted with a supporting crop of small grain. This provides excellent protection from winter wind erosion on sandy lands. Hairy vetch is used in many areas of the United States. Seed is available.

\section{Woody plants}

Trees and shrubs play an important role in the reclamation of mined lands and other disturbed areas (fig. 32). This is especially true in arid and semiarid areas. There are only a few developed cultivars of native and introduced woody plants that have potential for use on mined lands, but there is increased emphasis on such development. The only source of many species of planting materials may be hand collections from native or naturalized stands of woody plants. Seed contractors in the West can usually supply most of the seed of the planting stock. Adapted ecotypes must be obtained. Distinct ecotypes may occur within very short distances because of distinct spatial isolation barriers and abrupt changes in elevation and precipitation zones.

The woody plants discussed in this section represent only a fraction of the species that are potentially useful.

\section{Native trees adapted to arid sites}

Catclaw acacia, Acacia greggii A. Gray, is a native thicket-forming shrub or small tree growing at elevations of 1,000 to 4,500 feet ( 305 to $1,370 \mathrm{~m}$ ) in southwest Texas, southern New Mexico, central Arizona, southern California, and 
southern Nevada. It is in the ecotone at the north edge of the Chihuahua, Sonora, and Mohave Deserts along intermittent streams and dry washes. It tolerates drought very well and survives in areas with as little as 7 inches $(18 \mathrm{~cm})$ mean annual precipitation. Catclaw acacia has been tested on critical areas using transplant materials. The trials were small and the plants were kept grazed almost to soil level by deer, rabbits, and other rodents. The grazed plants form large crowns at the soil surface and are not killed by the close grazing. The species should be tested by direct seeding and in larger plantings. Inoculant is needed where plantings are made on milled mine tailings. Catclaw acacia has been widely used by nurseries for low maintenance landscaping. Plantings should be made where the recurring thorns on the stems will not be a hazard to people. Seed is not commercially available, but can be obtained through commercial jobbers. The collection area should be designated so that known ecotypes are used.

Blue paloverde, Cercidium floridum Benth., is a small tree found only in the Southwestern Desert plant growth region below an elevation of 3,500 feet $(1,068 \mathrm{~m})$. It is common along washes and flood plains in areas wtih a mean annual precipitation of 10 inches $(25 \mathrm{~cm})$ or more. The older bark and the new growth on stems and leaves are blue green. The flowers are yellow and showy. Blue paloverde has value for low maintenance landscaping, critical area stabilization, and reclamation of disturbed areas. It has been tested at several locations with limited success. Young plants are difficult to establish because they are damaged by wildlife. Blue paloverde is the Arizona state tree and is on the state protected list. Seed and plants are available commercially.

Littleleaf or yellow paloverde, also known as foothills paloverde,
Cercidium microphyllum (Torr.)

Rose and Johnst., is a small tree that grows to 25 feet $(7.6 \mathrm{~m})$. It is in the Southwestern Desert plant growth region on dry rocky slopes at elevations below 4,000 feet $(1,220 \mathrm{~m})$. It may develop pure stands. The flowers, bark, and new growth are yellow. Foothills paloverde has value for low maintenance landscaping, critical area stabilization, and mined-land reclamation. It has been tested at several locations with limited success because it is grazed by wildlife. Plants are not killed by grazing but are held at or near ground level. Seed and plants are available commercially.

Desertwillow, Chilopsis linearis (Cav.) Sweet, is a large shrub or small tree growing at elevations of 1,500 to 5,000 feet (457 to 1,525 $\mathrm{m})$. It is native to southern California, southern Nevada, southwestern Utah, southern New Mexico, and western Texas. Desertwillow is widely used as an ornamental plant because of the large, attractive, sweet-scented flowers that grow 3 to 6 inches ( 7 to $15 \mathrm{~cm}$ ) long.

'Barranco' desertwillow is a new release recommended for use in landscaping and soil stabilization plantings in MLRA's 30, 39, 40, 41, 42,77 , and 78 at elevations below 5,000 feet $(1,525 \mathrm{~m})$.

Mexican paloverde, Parkinsonia aculeata L., also known as retama and Jerusalem-thorn, is native to southern Texas and southwestern Arizona southward through Mexico to Central and South America. This species is naturalized in Florida and from eastern Texas to the Trans-Pecos area of Texas. It has also escaped from cultivation in southern New Mexico, southern Arizona, and southern California at elevations below 3,000 feet $(915 \mathrm{~m})$. It is usually found along sandy washes but tolerates salinity. Mexican paloverde is an attractive tree with green branches. It grows about 20 feet $(6.1 \mathrm{~m})$ tall. Mexican palo- verde is used extensively for landscaping in the Southwest. It is valuable for critical area stabilization and has performed well on mine tailings in southern Arizona in several plantings of containerized plants. Seed and plants are available commercially in that area.

Soaptree yucca. Yucca elata Engelm., is a large yucca growing as tall as 15 feet $(4.6 \mathrm{~m})$. It is common in the desert and desert grassland at elevations of 2,000 to 6,000 feet (610 to $1,830 \mathrm{~m}$ ) in southwestern Arizona, southern New Mexico, and western Texas. Soaptree yucca is best adapted to well-drained loamy to sandy soils where mean annual precipitation is 9 to 16 inches ( 23 to $40 \mathrm{~cm}$ ). It is used primarily for landscaping.

'Bonita' soaptree yucca is available in limited quantities for landscaping roadsides and other areas in New Mexico.

\section{Native trees adapted to semiarid sites}

Netleaf hackberry, Celtis reticulata Torr., is a deciduous large shrub or small tree that grows to a height of 25 feet $(7.6 \mathrm{~m})$. The berries are eaten by wildlife. Netleaf hackberry grows along watercourses and in canyons on limestone and gravelly and rocky soils. It grows in the upper desert, desert grasslands, and oak woodlands at elevations of 2,500 to 6,000 feet ( 763 to 1,830 $\mathrm{m})$. It is native from western Oklahoma and southern Colorado to western Texas, Arizona, southern Utah, southern Nevada, and eastern Oregon and California. Netleaf hackberry is valuable in soil stabilization plantings. Planting materials are available in limited quantities. No cultivars have been developed.

Desert ash, Fraxinus velutina Torr., is also known as Arizona ash or velvet ash. It is a deciduous tree with spreading branches. Desert ash grows to a height of 40 feet $(12 \mathrm{~m})$. It is found mainly along stream- 
banks and washes at elevations of 2,000 to 7,000 feet (610 to 2,135 $\mathrm{m})$. Desert ash grows from western Texas to southern California and is commonly used in southern Arizona. Desert ash has value in landscaping. Plants are available commercially.

Little walnut, Juglans microcarpa Berl., also known as Texas black walnut, is a shrub or small tree growing to a height of 30 feet $(9.2$ $\mathrm{m})$. It is native from the TransPecos area of Texas north to Oklahoma and in New Mexico at elevations of 3,500 to 7,000 feet $(1,068$ to $2,135 \mathrm{~m}$ ). Little walnut has been used locally and shows promise for use in soil stabilization and landscaping. The Arizona black walnut, Juglans major (Torr.) Heller, is closely related and is considered by some authors to be a variety of $J$. microcarpa. The nuts are a favorite food of squirrels.

Five species of junipers that develop into trees appear to have the highest potential for use in plantings on mined lands and other disturbed areas. They are all evergreens and tolerate drought. They provide soil stabilization and wildlife food and cover and are used extensively in windbreaks. They grow best on dry, well-drained, sunny sites.

Oneseed juniper, Juniperus monosperma (Engelm.) Sarg., grows from southwestern Kansas and west Texas to Arizona, Utah, and Idaho in areas of mean annual precipitation of 12 inches $(30 \mathrm{~cm})$ or more. In the southwestern part of its range it grows at elevations of 4,000 to 7,500 feet $(1,220$ to $2,287 \mathrm{~m})$. Oneseed juniper is generally 10 to 25 feet ( 3 to $7.6 \mathrm{~m}$ ) tall but on favorable sites may be taller. It may become a pest on rangelands in the Southwest. Planting materials are available in limited quantities in some local areas.

Western juniper, Juniperus occidentalis Hook., is an important forest tree in some areas of the
West. It grows to a height of 40 to 60 feet (12 to $18 \mathrm{~m}$ ). Western juniper is in the mountains of the Northwest from western Montana, Idaho, and Washington to Oregon and northern California. It is well adapted to deep sands and gravelly and stony soils in the mean annual precipitation zone of 10 to 18 inches (25 to $46 \mathrm{~cm})$.

Utah juniper, Juniperus osteosperma (Torr.) Little, tolerates drought better than most junipers. It grows in areas receiving as little as 8 inches $(20 \mathrm{~cm})$ mean annual precipitation. Utah juniper grows to a height of 15 to 30 feet (4.6 to 9.2 $\mathrm{m}$ ) in much of the intermountain area and the western slopes of the Central and Southern Rocky Mountains plant growth regions. Generally it grows at elevations of 3,000 to 7,500 feet ( 915 to $2,287 \mathrm{~m}$ ). One colony exists in southern Montana east of the Continental Divide at an elevation of about 4,000 feet $(1,300 \mathrm{~m})$. This species shows potential for use on mined lands and other disturbed areas.

Rocky Mountain juniper, Juniperus scopulorum Sarg., is a wideranging species growing over most of the West from North Dakota to West Texas and westward but is more common east of the Continental Divide. In the southwestern part of its range it grows at elevations of 5,000 to 9,000 feet $(1,525$ to $2,745 \mathrm{~m}$ ) and is limited to moist sites. In the Northern Great Plains plant growth region, Rocky Mountain juniper is best adapted to the mean annual precipitation zone of 14 to 20 inches ( 36 to $50 \mathrm{~cm}$ ) but also grows in the 12 -inch $(30 \mathrm{~cm})$ zone. Rocky Mountain juniper is widely used for windbreaks and wildlife plantings. It grows from 20 to 50 feet $(6$ to $15.3 \mathrm{~m})$ tall depending on the site and ecotype. There are many ecotypes throughout the range of this species. Many cultivars of horticultural forms are available, and common materials are available for use in windbreaks in the Great Plains.

Eastern redcedar, Juniperus virginiana L., is the common native juniper of the East and westward to the Great Plains. Eastern redcedar is superior to the Rocky Mountain juniper for use in western Oklahoma and western Texas at elevations lower than 3,500 feet $(1,068 \mathrm{~m})$. Rocky Mountain juniper has lower moisture requirements and is generally superior for use at elevations above 3,500 to 4,000 feet $(1,068$ to $1,220 \mathrm{~m}$ ). Planting materials of several horticultural cultivars and of common material of eastern redcedar are available.

Many species of native pines, genus Pinus, grow in the semiarid areas of the West. Only two of the more wide-ranging and more important species, ponderosa pine and pinyon, are described.

Pinyon, Pinus edulis Engelm., is an evergreen pine with a compact spreading crown. It grows to a height of 15 to 35 feet ( 4.6 to 10.7 m) at elevations of 5,000 to 7,500 feet $(1,525$ to $2,287 \mathrm{~m})$ in the southern part of the Central Rocky Mountains and Southern Plateaus plant growth regions. Pinyon tolerates low rainfall, hot summers, and shallow calcareous caliche soils. It grows mainly in the mean annual precipitation zone of 12 to 18 inches ( 30 to $46 \mathrm{~cm}$ ). Pinyon is generally available for use in landscaping plantings. The nuts are eaten by people and wildlife. Pinyon can be a pest on some rangelands.

Ponderosa pine, Pinus ponderosa Laws., is the widest ranging species of pine in the West. It grows from the Northern Great Plains plant growth region west to the Sierra Nevada and south to Arizona, Texas, and Mexico at 4,000 to 8,000 feet ( 1,220 to $2,440 \mathrm{~m}$ ). Ponderosa pine is a large evergreen that grows to a height of 80 to 125 feet ( 24 to $38 \mathrm{~cm})$. It is an important forest tree and has excellent longevity in 
windbreaks. It grows on a wide range of well-drained soils with a $\mathrm{pH}$ range from 4.5 to 9 . It is best adapted to a mean annual precipitation of 10 inches $(25 \mathrm{~cm})$ or more but in some areas is receiving as little as 7 inches $(18 \mathrm{~cm})$. Ponderosa pine is generally available in quantity for landscaping, windbreaks, and reforestration. It is important to use adapted ecotypes.

Several species of native oaks grow in the semiarid areas of the West. The oaks are important browse species for livestock and wildlife. The acorns are excellent wildlife food. Only the widely ranging Gambel oak is described.

Gambel oak, Quercus gambelii Nutt., is a highly variable and widespread species of oak. It ranges from a thicket-forming shrub to a tree 50 feet $(15.3 \mathrm{~m})$ tall. Gambel oak grows at elevations of 4,000 to 8,000 feet $(1,220$ to $2,440 \mathrm{~m})$ in the TransPecos, New Mexico, Arizona, Colorado, Utah, Nevada, and southern Wyoming. Gambel oak is most important because of its abundance and because it furnishes browse for livestock and deer when other more palatable browse is not available.

The acorns provide valuable mast for livestock, deer, and turkey. Gambel oak provides excellent wildlife cover.

\section{Native trees for mesic sites}

The species described here are those that grow in areas of higher precipitation or on sites with more favorable moisture.

Common hackberry, Celtis occidentalis L., is native to the East and westward to central North Dakota, south to western Nebraska, eastern Colorado, and western Oklahoma. It grows in areas with a minimum mean annual precipitation of 14 inches $(36 \mathrm{~cm})$. Common hackberry ranges from a deciduous shrub to a tree more than 100 feet $(30 \mathrm{~m})$ tall. It has shown promise for use in windbreaks and landscaping. The berries are eaten by many species of birds. Hackberry windbreaks established in the Northern Great Plains plant growth region are long lived, but establishment is difficult. Common hackberry is available in limited quantities. Cultivars for use in windbreaks should be available within a few years.

Fireberry hawthorn, Crataegus chrysocarpa Ashe, is native across the North and in the West southward to Nebraska, Colorado, and New Mexico. Fireberry hawthorn is a round-topped shrub or small tree that grows to a height of about 20 feet $(6 \mathrm{~m})$. It is a highly polymorphic species. The fruit is readily eaten by birds. The species shows potential for use on mined lands in the Dakotas in areas receiving a minimum of 15 inches $(38 \mathrm{~cm})$ mean annual precipitation.

Arizona cypress, Cupressus arizonica Greene, grows in the Southern Rocky Mountains and Southern Plateaus plant growth regions on gravelly slopes or cuts with a northern exposure. Arizona cypress grows from 30 to 90 feet ( 9.2 to $27 \mathrm{~m}$ ) tall and has been used for windbreaks and erosion control plantings. The primary use is for landscaping, for which several horticultural cultivars are available. Arizona cypress is recommended for plantings at elevations of 3,000 to 8,000 feet ( 915 to $2,440 \mathrm{~m}$ ) in the area of adaptation.

Green ash, Fraxinus pennsylvanica Marsh, is native deciduous tree that grows to a height of 60 feet (18 $\mathrm{m})$. It is native to the East and westward to central Montana, northeastern Wyoming, western Nebraska, western Kansas, and central Texas. It is mainly confined to bottom-land soils but performs well in cleantilled windbreaks in the Central and Northern Great Plains plant growth regions. It is the common shade tree of the Northern Great Plains plant growth region. Green ash grows in areas that receive a minimum of 15 inches $(38 \mathrm{~cm})$ mean annual precipitation. Planting materials of named cultivars and common materials are available in quantity. The species is made up of many ecotypes and it is important to obtain materials from adapted seed sources.

Honeylocust, Gleditsia triacanthos L., is a tall tree native in the East and westward to the eastern edge of the Great Plains. The thornless variety, $G$. triancathos inermis (L.) Zabel, is an excellent ornamental and windbreak tree for use in the Central Great Plains plant growth region and in the Northern Great Plains plant growth region into South Dakota and Wyoming with irrigation or on favorable sites. Honeylocust has not withstood long droughts in the plains west of its area of natural growth. Several grafted selections of thornless honeylocust are available commercially.

Osage-orange, Maclura pomifera (Raf.) Schneid., is a tree with milky sap and stout thorns that grows as tall as 60 feet $(18 \mathrm{~m})$. Osage-orange is commonly known as bois-d'arc. The natural range of the species is Arkansas, southeastern Oklahoma, eastern Texas, and possibly eastern Kansas. It has been widely planted in the East and naturalized in many areas. It is used for hedges and windbreaks in Kansas, Oklahoma, and Texas, and has been used in southeastern Oregon and Washington. Planting materials are available.

American plum, Prunus americana Marsh., grows over most of the North and East and in the Rocky Mountains south to New Mexico. American plum is a shrub or small tree limited to deep soils in areas with a minimum of 16 inches (40 $\mathrm{cm}$ ) mean annual precipitation. It is useful for windbreaks, erosion control, and wildlife plantings. Planting material is available in quantity for common materials and for several cultivars selected primarily for fruiting characteristics. The species is highly variable, and 




Figure 33. Fourwing saltbush (Atriplex canescens).

only material of known adaptation should be planted. Because American plum has a wide range of suckering habits, selections should depend on the planned use.

Bitter cherry, Prunus emarginata Dougl., is native from western Montana to southern British Columbia and Washington and south to Oregon, southern California, Nevada, Arizona, and southwestern New Mexico. Bitter cherry is a thicketforming large shrub or small tree. It is a valuable wildlife food plant as browse for mule deer. The fruit is eaten by upland game and other birds. Bitter cherry has potential for use on mined lands in its area of adaptation. It grows best in areas with mean annual precipitation of 18 inches $(46 \mathrm{~cm})$ or more.

Chokecherry, Prunus virginiana $\mathrm{L}$., is a shrub or small tree that is widely distributed in the United States. It is most commonly used in
It is available in limited quantities for use in the Northern Great Plains plant growth region.

New Mexico locust, Robinia neomexicana A. Gray, is a spiny shrub or small tree growing 6 to 25 feet (1.8 to $7.6 \mathrm{~m})$ tall. It is thicket forming and spreads freely from stumps and roots. New Mexico locust grows in moist soils along streams at elevations of 4,000 to 8,500 feet $(1,220$ to $2,590 \mathrm{~m}$ ) in the Trans-Pecos, west through New Mexico and Arizona, and north to Colorado, Utah, and Nevada. New Mexico locust is difficult to eradicate. It is good browse for goats and mule deer.

Western soapberry, Sapindus drummondii Hook. and Arn., is a tree as tall as 50 feet $(15.3 \mathrm{~m})$. It grows in moist soils from Texas to Kansas west to southeastern Colorado, New Mexico, and Arizona at elevations of 2,500 to 6,000 feet (762 to $1,830 \mathrm{~m}$ ). Soapberries contain the poison saponin, which has an objectionable taste. The berries are not browsed by livestock. Western soapberry is used for ornamental and windbreak plantings.

\section{Native shrubs}

Native shrubs are important for use on mined lands and other disturbed areas. They provide the best opportunity for long-term reclamation on many arid sites, and in some of the desert areas in the Southwest they are the major natural vegetation. Shrubs are valuable for soil stabilization and wildlife. There is increased interest in the use of shrubs and in developing cultural techniques for producing and harvesting these species. Seed of a few of the species can be produced commercially and sown directly on the sites; seed of others is limited to hand harvests of native stands. Many of the native shrubs can be established only by using planting stock. Irrigation may be necessary to establish any vegetation on some sites. Shrubs are generally planted in a 
mixture of species adapted to the selected site. Plummer, et al. (1968) present excellent information on the characteristics and adaptation of many shrubs of the intermountain area.

\section{Native shrubs for arid sites}

\section{Mescat acacia, Acacia constricta} Benth., also known as whitethorn, is a spiny shrub that may grow 15 feet $(4.6 \mathrm{~m})$ tall. Mescat acacia is adapted to a wide range of soils but is usually found in sandy or caliche soils at elevations of 1,500 to 4,500 feet (460 to $1,370 \mathrm{~m}$ ) and rarely at higher elevations. Mescat acacia mainly grows west of the Pecos River in Texas and westward in southern New Mexico and Arizona. It has little value as a forage plant, has been reported as poisonous to livestock, and is little used. Mescat acacia tolerates drought and shows promise for soil stabilization in arid areas. It can be a weed on rangelands. Planting materials are available only from the harvest of native plants.

Fourwing saltbush, Atriplex canescens (Pursh) Nutt., is a widely distributed shrub in the West (fig. 33). It grows naturally from the western Great Plains almost to the Pacific Ocean, and from Canada to Mexico. It is palatable, nutritious, and a good forage producer. It has wide adaptability to soils and grows on soils ranging in texture from clay to sand. It is tolerant of salinity. Fourwing saltbush grows in areas with mean annual precipitation of less than 6 inches $(15 \mathrm{~cm})$ to about 15 inches $(38 \mathrm{~cm})$. There is a wide range of variability among isolated populations. Populations range from dwarf forms less than 3 feet $(1 \mathrm{~m})$ tall to plants more than 6 feet $(1.8$ $\mathrm{m})$ tall. Individual plants generally have only male or female flowers (dioecious), and the seeds (utricles) vary in size and in length and shape of the wings. Observations of assemblies at plant materials centers indicate that several cultivars are needed. Each cultivar may have a relatively small area of adaptation. Seed production will vary for the various growth forms. Some types do not lend themselves to cultural production and mechanical harvest. 'Wytana' fourwing saltbush is a dwarf form collected in central Montana. As reported by Stroh and Thornburg (1969), it can be grown successfully as a cultivated row crop and harvested mechanically. 'Wytana' is adapted to Montana, eastern Wyoming, and the western Dakotas. It was released by the Montana and Wyoming Agricultural Experiment Stations and SCS. 'Wytana' has been drilled successfully on mine spoils and in range seedings in mixtures with grasses. Germination in the field has been better than in the laboratory. About one-half pound of dewinged seed per acre $(0.56 \mathrm{~kg} / \mathrm{ha})$ provides enough plants in the mixture. Seedling vigor is outstanding, and plants 18 inches $(0.5$ m) tall are common at the end of the first growing season in the Northern Great Plains plant growth region. Studies should be made that will lead to releases of additional cultivars and determination of the adaptation of seed sources from wild harvests for those forms that cannot be adapted to cultural management.

Quailbush or big saltbush, Atriplex lentiformis (Torr.) S. Wats., is a large, bushy, semievergreen shrub 6 to 10 feet $(1.8$ to $3.1 \mathrm{~m})$ tall and 8 to 15 feet ( 2.4 to $4.6 \mathrm{~m}$ ) in diameter. Quailbush grows on alkaline flats in the desert at elevations of 300 to 2,000 feet ( 92 to $610 \mathrm{~m}$ ) or in some places to 4,000 feet $(1,280 \mathrm{~m})$. It grows in New Mexico, Arizona, and southern California, and northward into southern Utah and Nevada. Quailbush is especially abundant at low elevations in the Southwestern Desert plant growth region. It is a fairly important browse plant for mule deer and is browsed by cattle during the winter and spring. Quail- bush furnishes excellent cover for wildlife. It has potential for use on mined lands and other disturbed lands in arid areas. It has good seedling vigor and grows rapidly from seed. Good results have been obtained at lower elevations of the Central Arizona Basin and Range (MLRA 40) where there is a mean annual precipitation of 7 inches (18 $\mathrm{cm})$. Seed is available in limited quantities commercially.

Nuttall saltbush, Atriplex nuttallii Wats., is a highly variable, palatable, small shrub seldom more than 3 feet $(0.9 \mathrm{~m})$ tall. It grows on alkaline clay soils in the Northern Great Plains plant growth region and the intermountain areas at elevations of 4,000 to 7,500 feet $(1,220$ to $2,287 \mathrm{~m}$ ). It is often a dominant plant in the 5-to 9-inch (13 to 23 $\mathrm{cm}$ ) mean annual precipitation area of the Big Horn Basin and Red Desert areas of Wyoming. It is an important forage plant for livestock and wildlife. Direct seedings of Nuttall saltbush have produced excellent cover and soil stabilization on mined lands and other disturbed areas. Nuttall saltbush can be used for seed production. It is highly variable and has numerous ecotypes. Only planting materials from adapted seed sources should be used. Considerable work is being done with this species, and cultivars for several areas should be available within a few years.

Desert saltbush, Atriplex polycarpa (Torr.) S. Wats., is a deciduous shrub that is usually less than 3 feet $(0.9 \mathrm{~m})$ tall. It is also known as allscale or cattle saltbrush. Desert saltbush is often the dominant plant at elevations below 2,500 feet (762 $\mathrm{m}$ ) in the Southwestern Desert plant growth region from southern California and Arizona to southern Nevada and southward to Mexico. The mean annual precipitation for this area is 3 to 7 inches ( 8 to 18 $\mathrm{cm})$. Desert saltbush often forms pure stands on gravelly and sandy saline soils or is mixed with creosote- 
bush. In pure stands the plants may be evenly spaced and symmetrical. Desert saltbush is probably the most important forage plant in the Sonora Desert for livestock and wildlife. It has been tested at several locations on disturbed lands and as vegetative cover on watershed structures.

Desert saltbush is easily established from direct seeding or may be transplanted as containerized stock. Seed is available in limited quantities or can be collected from native stands.

Desertbroom or broom baccharis, Baccharis sarathroides Gray, is a branched, broomlike evergreen shrub that is 3 to 9 feet $(0.9$ to 2.7 $\mathrm{m})$ tall. It grows on sandy and gravelly washes of low hills or desert grasslands at elevations of 1,000 to 5,000 feet ( 305 to $1,525 \mathrm{~m}$ ) in western New Mexico, Arizona, and California. Desertbroom is not palatable to livestock. It is used as an ornamental in the Southwest and has value for soil stabilization.

Rubber rabbitbrush, Chrysothamnus nauseosus (Pall.) Britt., is a highly variable species that ranges from Saskatchewan to British Columbia south to western Texas and Baja California. Rubber rabbitbrush grows from 1 to 7 feet ( 0.3 to 2.7 $\mathrm{m})$ tall on dry slopes and mesas at elevations of 2,000 to 8,000 feet (610 to $2,440 \mathrm{~m}$ ). It is browsed by wildlife, though it is reported to be a poisonous weed when eaten in quantity. Rubber rabbitbrush has been established by direct seeding and from transplants. Planting materials are available only from harvests of native plants.

White brittlebush, Encelia farinosa A. Gray, is native to the Southwestern Desert plant growth region. It grows at elevations as high as 3,000 feet $(915 \mathrm{~m})$ in southern Nevada, southern and western Arizona, and southern California on dry rocky desert slopes. White brittlebush is a many-branched, grayishgreen shrub with yellow flowers about 2 inches $(5 \mathrm{~cm})$ in diameter.
It grows to a height of about 3 feet $(0.9 \mathrm{~m})$. White brittlebush has value for use in low maintenance landscaping, critical area stabilization, and reclamation of disturbed areas. Little is known about its value for wildlife and livestock. Seed and plants are available in limited quantities. It is easily transplanted or can be established by direct seeding.

Green ephedra, Ephedra viridis Coville, is a small shrub with crowded, erect, rigid, broomlike branches. It grows as tall as 4 feet $(1.2 \mathrm{~m})$. Green ephedra grows on rocky or sandy slopes at elevations of 3,000 to 7,500 feet ( 915 to 2,287 m) in New Mexico, Arizona, and southern California northward to Utah and Colorado. Green ephedra is the most widely distributed species of Ephedra. Other species grow at elevations as low as sea level. Green ephedra is an important browse plant for livestock and is used by mule deer and blacktailed deer. Green ephedra has been successfully established by direct seeding. Seed is available only from the harvests of native plants.

California buckwheat, Eriogonum fasciculatum Benth., grows in the Great Basin Intermontane and Southwestern Desert plant growth regions. It is most common on sands or dry rocky sites at elevations between 2,000 and 4,500 feet ( 610 and $1,370 \mathrm{~m})$. The plants range from 1 to 3 feet $(0.3$ to $0.9 \mathrm{~m})$ tall, depending on the site conditions. The flowers are pinkish or white and appear when moisture is available. California buckwheat has value for critical area stabilization, landscaping, and the reclamation of disturbed areas. It is grazed by livestock and wildlife. Quail use it for food and cover. Seed is available commercially in limited quantities. Plants are available for nurseries in the area of adaptation.

Winterfat, Eurotia lanata (Pursh) Moq. (Ceratoides lanata (L.) C. A. Mey.), is a bushy perennial that grows to 3 feet $(0.9 \mathrm{~m})$. Winterfat is valuable on winter ranges where it furnishes palatable and nutritious forage for cattle and sheep and is relished by deer and elk. Winterfat grows on a wide range of soils and in areas with as little as 5 inches $(13 \mathrm{~cm})$ mean annual precipitation. It grows well on moderately alkaline soils and is often in almost pure stands on calcareous soils in desert valley bottoms. Winterfat grows at elevations of 2,000 to 8,000 feet (610 to $2,440 \mathrm{~m}$ ) and may grow higher, depending on the location. It is widely distributed from Saskatchewan to Washington and south to Texas, Arizona, and California. Winterfat is readily established from seed and has excellent seedling vigor. It is a highly variable species, and only materials of known adaptation should be used. Winterfat is easily cultivated and is harvested mechanically. The major deterrent to its use is the difficulty and expense of processing the seed and the short seed viability. Seed is available only from harvests of native stands.

Triangle bursage, Franseria deltoidea Torr., is native to the Southwestern Desert plant growth region below 2,800 feet ( $854 \mathrm{~m}$ ) elevation. Plants are abundant on desert mesas and dry rocky slopes and canyons. Triangle bursage is often found growing in almost pure stands or mixed with creosotebush. The plants are generally about 6 inches $(15 \mathrm{~cm})$ tall and 12 inches $(30 \mathrm{~cm})$ wide. Triangle bursage produces large quantities of seed during favorable years. It has value for critical area stabilization. Little is known about the use of this plant by wildlife or livestock. It can be established by direct seeding or with containerized plants. Seed and plants are available in limited quantities.

White bursage, Franseria dumosa A. Gray, grows in the Southwestern Desert plant growth region at elevations below 3,000 feet $(915 \mathrm{~m})$ in southern Nevada, central and south- 
ern Arizona, and southern California. The plants are low growing, many branched, compact, and spiny. Abundant seed is produced during favorable years. White bursage tolerates salinity and drought. Much of the area where it grows has a mean annual precipitation of 2 to 4 inches ( 5 to $10 \mathrm{~cm}$ ). Ths is one of the most abundant shrubs of the desert and over large areas is associated with creosotebush. It is locally important as livestock and sheep forage and is used by wildlife. White bursage has value for critical area stabilization, wildlife, and for restoring cover on arid lands. Seed and plants are available in limited quantities.

Creosotebush, Larrea divaricata Cav., grows in the Southwestern Desert, Southern Plateaus, and Southern Plains plant growth regions at elevations from sea level to about 5,000 feet $(1,525 \mathrm{~m})$. The mean annual precipitation in much of the area it inhabits ranges from 2 to 7 inches (5 to $18 \mathrm{~cm}$.) Creosotebush blooms and sets fruit throughout the year when moisture is available. It is not eaten by livestock and is reported to be poisonous. It is highly flammable. Creosotebush has value for low-maintenance landscaping and reclamation of disturbed lands in the desert Southwest. It provides cover for wildlife and is an important food source for the herbivorous lizard, the chuckwalla. Creosotebush is easily propagated and can be established by direct seeding or with containerized plants. Seed and plants are available commercially.

Rough menodora, Menodora scabra Gray, also known as twinberry, is a small shrub native to the Southwestern Desert and Southern Plateaus plant growth regions. It grows on desert grassland and chaparral between 1,500 and 7,000 feet (460 and 2,135 m). The plants are woody at lower elevations and suffrutescent at higher elevation. Rough menodora plants are used by all classes of livestock and by wild- life. The plants range in size from 6 inches $(15 \mathrm{~cm})$ to more than 2 feet $(60 \mathrm{~cm})$ tall. Rough menodora has potential for use in low-maintenance landscaping, critical area stabilization, and mined-land reclamation.

Dunebroom or parryella, Parryella filifolia Tor. and Gray, is a small, many-branched shrub about 3 feet $(0.9 \mathrm{~m})$ tall. It grows in northwestern New Mexico and northeastern Arizona at elevations of 4,400 feet to 6,000 feet $(1,342$ to 1,830 $\mathrm{m})$. One collection has been made in southwestern Colorado. Dunebroom grows on the rolling, treeless, sandy plains of this area. It is considered unpalatable to livestock. Dunebroom is easily propagated from seed and is used on sandy soils for soil stabilization. Seed is obtained from harvests of native stands.

Jojoba, Simmondsia chinensis (Link.) Schneid., also known as goatnut, is a dense, evergreen, drought-resistant shrub that grows to a height of 3 to 9 feet ( 0.9 to 2.7 $\mathrm{m})$. The natural distribution is limited to the Southwestern Desert plant growth region at elevations of 1,000 to 4,500 feet ( 305 to $1,370 \mathrm{~m}$ ) in the upper desert and chaparral. Jojoba is an important browse plant and is also used by deer. The fruit is eaten by white-winged dove and other wildlife. Jojoba is easily established from seed and shows promise for use in soil stabilization plantings.

\section{Native shrubs adapted to semiarid} sites

\section{Black sagebrush, Artemisia} arbuscula nova (A. Nels.) Cronq., is a low shrub that grows on dry rocky ridges and shallow soils from Montana to New Mexico and in northern Arizona and California. Black sagebrush often grows in association with big sagebrush. It is a highly variable species. In general it is more palatable than big sagebrush and is used by sheep and big game. Black sagebrush is success- fully established by direct seeding. It has potential for use on disturbed areas. Seed is available only from harvest of native plants. It is possible to make selections of this species for specific uses and areas.

Silver sagebrush, Artemisia cana Pursh, is a small shrub that may grow to 6 feet $(1.8 \mathrm{~m})$. It grows in the Northern Great Plains, the Rocky Mountains, and the Great Basin Intermontane plant growth regions, and in the intermountain areas. Silver sagebrush grows on a wide range of well-drained soils associated with grasses in the area of climatic adaptation where the mean annual precipitation is 10 to 14 inches ( 25 to $36 \mathrm{~cm}$ ) or more. Its moisture requirements are greater than those of big sagebrush. Silver sagebrush is an important livestock and wildlife browse species where it is common. It has potential for use in range seeding mixtures and for soil stabilization.

Big sagebrush, Artemisia tridentata Nutt., is a widely distributed, highly variable, small to large shrub of the West. It grows on a wide range of well-drained soils in areas with as little as 10 inches $(25 \mathrm{~cm})$ mean annual precipitation. Some ecotypes of big sagebrush are important livestock browse plants in autumn and winter. It is an important wildlife food for deer, bighorn, antelope, and upland game birds. Big sagebrush increases on ranges in poor condition and may become a pest. The various forms of big sagebrush from different geographic areas vary greatly in palatability, growth form, and seed production. The shrub grows rapidly and can be used for soil stabilization plantings. The inherent variability of this species provides the opportunity to select better ecotypes and to breed more palatable strains.

False-mesquite, Calliandra eriophylla Benth., is a low, densely branched deciduous shrub that may grow almost prostrate to about 3 
feet $(0.9 \mathrm{~m})$ tall. It spreads by underground stems. It has attractive globular purple flowers. Falsemesquite grows from western Texas to California at elevations of 2,000 to 5,000 feet ( 610 to $1,525 \mathrm{~m}$ ).

False-mesquite is a valuable forage plant furnishing yearlong browse for all classes of livestock. It is highly palatable to deer. The seeds are eaten by upland game birds.

False-mesquite is a valuable erosion control plant because it withstands close grazing and spreads by underground sprouts. It has potential for use on mined lands and other disturbed areas.

Coves or desert cassia, Cassia covesii Gray, is a low, suffrutescent, perennial legume growing in the Sonora and Mohave deserts of Arizona and California. Normal height is about 12 inches $(30 \mathrm{~cm})$. Native stands in the lower Sonora desert are in low areas that receive run-in moisture. In the Mohave desert cassia grows on rocky slopes up to 3,000 feet $(915 \mathrm{~m})$ in elevation.

Flowers are yellow and bloom throughout the year, depending on available moisture. Cassia is being field tested on mine tailings in southern and central Arizona.

Many species of Ceanothus grow throughout the United States. Generally they are large shrubs or small trees and are mainly on soils that are mildly alkaline to medium acid. Ceanothus has the ability to fix nitrogen in much the same manner as legumes. In general the plants are palatable to livestock and are browsed by deer and elk. They are also used by upland game birds and other birds. Only five of the many species of Ceanothus are described in the text. Three species, Ceanothus fendleri, $C$. greggii, and $C$. martinii are considered to be adapted to semiarid areas; and $C$. prostratus and $C$. velutinus are better adapted to mesic sites.

Fendler ceanothus, Ceanothus fendleri Gray, is a thicket-forming spinescent shrub that grows to a height of about 3 feet $(0.9 \mathrm{~m})$. It is also known as buckbrush. Fendler ceanothus grows at elevations of 3,000 to 10,000 feet (915 to 3,050 $\mathrm{m})$ from the Trans-Pecos, Texas, area to New Mexico and Arizona, and north to Wyoming and South Dakota. Fendler ceanothus is an important browse plant for deer and cattle. It is used for landscaping and for erosion control plantings. It is winter hardy.

Desert ceanothus, Ceanothus greggii Gray, is a stout, heavily branched, generally evergreen shrub that grows to a height of 5 feet $(1.5 \mathrm{~m})$ at elevations of 3,000 to 7,000 feet ( 915 to $2,135 \mathrm{~m}$ ). It is mainly on dry clayey to sandy soils from the Trans-Pecos area of Texas, New Mexico, west to southern California, and north to Utah and Colorado. Desert ceanothus provides good winter browse. It has potential for use in disturbed areas and for low-maintenance landscaping.

Martin ceanothus, Ceanothus martinii M. E. Jones, is a small or large shrub on dry well-drained soils. It grows at about 7,500 feet $(2,287$ $\mathrm{m}$ ) in Utah, Nevada, and northern Arizona. It is very palatable to sheep and cattle. Martin ceanothus has potential for use for wildlife and for soil stabilization plantings.

Spiny hackberry, Celtis pallida Torr., is an attractive spiny, spreading evergreen shrub that grows from 3 to 10 feet $(0.9$ to $3.1 \mathrm{~m})$ tall and occasionally taller. Spiny hackberry is in the southern part of the Central Great Plains, Southern Plains, and Southern Plateaus plant growth regions. It grows on gravelly or welldrained sandy soils at elevations of 1,500 to 3,000 feet ( 460 to $915 \mathrm{~m}$ ). It provides excellent cover for gambel quail and other birds. It is unattractive to livestock because of its spines. Spiny hackberry has potential for use in soil stabilization and wildlife plantings.
Curlleaf mountainmahogany, Cercocarpus ledifolius Nutt., ranges from eastern Washington to California, northern Arizona, and north to Colorado and Montana. It grows at 2,000 to 4,500 feet ( 619 to 1,370 $\mathrm{m})$ in the northern part of its range and up to 9,000 feet $(2,745 \mathrm{~m})$ in the southern part. It grows on a wide range of soils but is most common on shallow limestone ridges where it forms dense stands. Curlleaf mountainmahogany is a large evergreen shrub with leathery leaves that grows to a height of 15 to 20 feet ( 4.6 to $6 \mathrm{~m}$ ). It is drought resistant and tolerates high temperatures. It furnishes poor livestock forage but is very important browse and cover for mule deer and elk. Curlleaf mountainmahogany has potential for soil stabilization. Seed is available only from harvests of native stands.

True mountainmahogany, Cercocarpus montanus Raf., grows from South Dakota and Montana to New Mexico and Arizona, and in Nevada and California where it reaches tree form. It also grows in the panhandle and Trans-Pecos area of Texas. In the southern part of the range of true mountainmahogany it grows at elevations from 4,500 to 10,000 feet $(1,370$ to $3,050 \mathrm{~m})$. It is on a wide range of sites and may grow in almost pure stands. It is an attractive shrub with birch-like leaves that grows to a height of about 12 feet $(3.7 \mathrm{~m})$. It is evergreen in the southern part of its range but is generally considered to be deciduous. True mountainmahogany is an important browse species for livestock and big game. It has potential for use in soil stabilization and wildlife plantings. Seed is available commercially or from harvests of native plants. True mountainmahogany is a highly variable species, and only planting materials from adapted sources should be used.

'Montane' true mountainmahog- 
any is a recently released cultivar from New Mexico.

Cliffrose, Cowania mexicana D. Don, is a leafy, evergreen shrub 3 to 12 feet $(0.9$ to $3.7 \mathrm{~m})$ tall. Cliffrose grows from southern Colorado and Utah west to California east of the Sierra Nevada and south into New Mexico and Mexico. It is at elevations of 4,000 to about 8,000 feet $(1,220$ to $2,440 \mathrm{~m})$. Cliffrose grows mainly in limestone areas but also on granitic, volcanic, and other soils. Cliffrose is an important browse species for cattle, sheep, and deer. Plantings have grown well on raw soils and cliffrose should be valuable for soil stabilization on disturbed areas. Seed is available from harvests of native stands.

Sulfur eriogonum, Eriogonum umbellatum Torr., is one of a group of yellow-flowered half-shrub or shrubby species of eriogonums. It grows from Wyoming to Washington and south to California and northern Arizona. Several species of eriogonums, also known as buckwheats, show promise for use in soil stabilization. The eriogonums are used by livestock, big game, and upland game birds.

Apacheplume, Fallugia paradoxa (D. Don) Endl., is an attractive many-branched, mainly evergreen shrub about 3 to 6 feet ( 0.9 to 1.8 $\mathrm{m}$ ) tall. It grows on gravelly slopes and alluvial plains and along dry arroyos at elevations of 3,000 to 8,000 feet ( 915 to $2,440 \mathrm{~m}$ ). It is in west and northwest Texas, north to southern Colorado, and west through Arizona to Utah, Nevada, and California. Apacheplume shows potential for soil stabilization plantings. It provides good browse for cattle and deer. Seed is available only from harvests of native stands.

New Mexico forestiera, Forestiera neomexicana A. Gray, is an attractive deciduous shrub or small tree 4 to 12 feet ( 1 to $3.7 \mathrm{~m}$ ) tall that may grow to 20 feet $(6 \mathrm{~m})$. It grows from southern Colorado and Utah to western Texas, New Mexico, Arizona, and California. New Mexico forestiera has little forage value for livestock or big game animals. It is mainly used as an ornamental plant. 'Jemez' New Mexico forestiera is a cultivar released in New Mexico primarily for roadside beautification plantings.

Bladderpod, Isomeris arborea Nutt., is a native deciduous shrub or half-shrub that grows to a height of 3 to 6 feet $(0.9$ to $1.8 \mathrm{~m})$. It is in the California Valleys and Foothills and Southwestern Desert plant growth regions at elevations of 200 to 3,000 feet $(61$ to $915 \mathrm{~m})$. It generally grows on alkaline soils. Though bladderpod grows slowly, it has shown promise in roadside and other disturbed-land plantings made by direct seeding or with seedlings. Trial plantings are being continued.

Creeping juniper, Juniperus horizontalis Moench., is a low-growing creeping evergreen conifer. It grows in much of the Northeast and westward to Montana, Colorado, and Nebraska. Creeping juniper grows on a wide range of soils but mostly on sands. It is used sparingly as browse. Many horticultural forms of varying colors and matting characteristics are available. Creeping juniper is valuable in soil stabilization plantings on sandy sites.

Green molly or green molly kochia, Kochia americana S. Wats., grows in the Great Basin Intermontane and Northern and Central Intermountain Desertic Basins plant growth regions. Where it is sufficiently abundant it is a valuable forage plant. It grows on dry open plains, commonly in saline soil. Green molly grows to a height of about $1 \frac{1 / 2}{2}$ feet $(46 \mathrm{~cm})$. It shows promise for use in soil stabilization plantings.

Range ratany, Krameria parvifolia Benth., is a low-branched shrub that grows about 2 feet $(60$ $\mathrm{cm}$ ) tall on dry rocky slopes and plains at elevations of 500 to 5,000 feet ( 153 to $1,525 \mathrm{~m}$ ). Range ratany grows from west Texas to New Mexico, southern Nevada, Arizona, and southern California. Range ratany is an important range species and shows promise for use in reclamation of disturbed areas.

Antelope bitterbrush, Purshia tridentata (Pursh) DC, is an intricately branched shrub growing to a height of 2 to 10 feet $(0.6$ to $3.1 \mathrm{~m})$. Bitterbrush is on soils that range from sands to clays at elevations of 3,500 to 9,000 feet $(1,068$ to 2,745 $\mathrm{m})$. It grows from New Mexico and Colorado, west through northern Arizona to California, and north to Idaho, Montana, and British Columbia. The prostrate stems, rooting where they touch the ground, make this plant valuable for controlling soil erosion. Bitterbush is one of the most important western browse plants for livestock and big game. It is easily established and makes good growth on well-drained soils in the mean annual precipitation zone of 10 to 25 inches ( 25 to $64 \mathrm{~cm}$ ). Bitterbrush as a highly variable species, and plantings should be made with seed from adapted sources.

Littleleaf sumac, Rhus microphylla Engelm., is a deciduous shrub that grows as tall as 6 feet $(1.8 \mathrm{~m})$.

It is on gravelly and sandy mesas at 4,000 to 6,000 feet $(1,220$ to $1,830 \mathrm{~m}$ ) from western Texas to southeastern Arizona. Littleleaf sumac is not very palatable to livestock but is used by deer. Littleleaf sumac has potential for use in soil stabilization plantings.

Skunkbush sumac, Rhus trilobata Nutt., also known as squawbush, is a dense shrub growing 2 to 15 feet $(0.6$ to $4.6 \mathrm{~m})$ tall. This is a wideranging and polymorphic species from Illinois to Nebraska and west to Oregon, California, and Mexico. Skunkbush sumac is poor livestock forage but provides good browse for big game. The seeds are used by many species of birds. Skunkbush sumac has value for wildlife, soil 
stabilization, and windbreak plantings. Materials are commonly available but must be carefully selected from adapted seed sources.

'Bighorn' skunkbush sumac is a cultivar developed in New Mexico. The original source of the material came from a collection in the Bighorn Basin of Wyoming. 'Bighorn' is a tall-growing form that has performed well in trials from New Mexico to Montana and North Dakota.

Native roses, Rosa spp. L., grow on favorable sites throughout most of the West except in the warmest and most arid areas. Many of the native roses are referred to as woods rose, Rosa woodsii Lindl., which is a common wide-ranging species. Because of the difficulty of identifying roses, only a general discussion is attempted.

The roses are valuable plants for erosion control. Many are climbing or thicket forming and produce a dense soil cover. Many roses provide forage for livestock and big game. The spines provide natural protection for the plants so that they are not overused. This increases their value for erosion control. Roses hold their fruit most of the winter and provide food for long periods for wildlife and for many species of birds, including upland game birds. Roses also provide food and shelter for small mammals. They are valuable in conservation plantings and deserve more attention. Plantings from seed, transplants, and cuttings have been made with good success.

Skeletonleaf goldeneye, Viguiera stenoloba Blake, is a many-branched shrub that grows to 4 feet $(1.2 \mathrm{~m})$. It is on dry, sunny, rocky areas of the Pecos and Rio Grande River basins of western Texas and southern New Mexico. Skeletonleaf goldeneye provides limited livestock browse. It has attractive yellow flowers. It has been used for diversity in range seedings, and has potential for use in soil stabilization plantings.

\section{Native shrubs for mesic sites}

Serviceberries, Amelanchier spp. Med., grow throughout most of the United States and some species are in all the western states. Most are small to large shrubs but a few grow to the size of small trees. Many species are highly variable. Most serviceberries are best adapted to soils that are moderately moist to moist. Serviceberries are important for wildlife food and cover. Many species of birds and upland game eat the fruit. Serviceberries produce abundant seed crops in favorable years and are easily harvested by hand. They have potential for use in wildlife and soil stabilization plantings.

Leadplant, Amorpha canescens Pursh, is a deep-rooted brushy shrub that grows to a height of 1 to 3 feet $(0.3$ to $0.9 \mathrm{~m})$. It is common throughout the Northern and Central Great Plains plant growth regions. It grows on sand and deep soils with good moisture conditions in areas with a minimum of 15 inches $(38 \mathrm{~cm})$ mean annual precipitation. Leadplant grows well in mixtures with grasses. Seed is available in limited quantities from harvest of native stands.

Indigobush, Amorpha fruticosa $\mathrm{L}$., is a highly variable shrub that grows from 5 to 10 feet ( 1.5 to 3.1 $\mathrm{m})$ tall. It is on moist, generally calcareous soils from North Dakota to Texas and west in the Southern Plateaus plant growth region to Arizona. In Arizona it is at elevations of 5,000 to 6,000 feet $(1,525$ to $1,830 \mathrm{~m}$ ) on rich moist soils in canyons and along streams. Indigobush is used as borders in windbreak plantings, in soil stabilization plantings in gullies and along streams, and for landscaping. Planting materials are available for some areas of the Great Plains.

Oregon-grape, Berberis repens Lindl., is a low evergreen shrub. It grows from the Black Hills of
South Dakota to Wyoming and British Columbia and south to New Mexico, Arizona, the Trans-Pecos of Texas, and California. It is mainly on well-drained soils in coniferous forests. The creeping rootstocks make it an excellent ground cover plant. Oregon-grape has potential for use in soil stabilization plantings. The plants furnish some browse for mule deer, and the berries are eaten by many birds and mammals.

Butterflybush, Buddleia scorioides H.B.K., is an aromatic shrub covered with hairs. It grows to a height of about 3 feet $(0.9 \mathrm{~m})$. Butterflybush grows from southwestern Texas to New Mexico on dry, sunny, open sites. It is fairly palatable and has potential for use in range seeding mixtures and as soil stabilization plantings.

Squawcarpet, Ceanothus prostratus Benth., is a small, prostrate evergreen shrub. It grows in the Northern Rocky Mountains plant growth region and intermountain areas from Washington and Idaho south to Nevada and California. The branches root in contact with the soil and form a matlike ground cover. Squawcarpet provides fair browse for mule deer. It has potential for soil stabilization plantings.

Snowbrush ceanothus, Ceanothus velutinus Dougl., is a small to large evergreen shrub with a deep taproot. It grows on moist sites in the higher elevations of the Black Hills of South Dakota and from British Columbia south to Colorado and California. It is a pioneer, forming thickets in logged or burned-over areas. It is used as browse by deer. Snowbrush ceanothus has potential for use in soil stabilization plantings.

Virginsbower, Clematis ligusticifolia Nutt., grows from western Canada and North Dakota south to New Mexico, Arizona, and California. Virginsbower is a vigorous climbing vine. It is herbaceous above but somewhat woody near the base. It has been cultivated for many years 
as an ornamental. It is browsed by deer. Virginsbower shows promise for use in soil stabilization plantings on mined lands and other disturbed areas.

Redosier dogwood, Cornus stolonifera Michx., is a stoloniferous, thicket-forming shrub that grows from 3 to 9 feet ( 0.9 to 2.7 m) tall. It grows across the northern United States and south to New Mexico, Arizona, and California. The attractive red stems make it a popular ornamental. It grows mainly in sandy swamps or along streams at elevations of 1,500 to 9,000 feet ( 460 to $2,745 \mathrm{~m}$ ). It is a variable species, and many horticultural forms and common materials are available. It has been widely used in soil stabilization plantings and is readily established from hardwood cuttings.

Hopseedbush, Dodonea viscosa Jacq., is a shrub that grows to 12 feet feet (4 m) (fig. 34). It is at elevations of 2,000 to 4,000 feet ( 610 to 1,220 $\mathrm{m}$ ) on dry rocky slopes, commonly on limestone, in southern Arizona and Mexico. It is unpalatable to livestock and tends to increase on overgrazed ranges. The plant contains saponin and is poisonous. It has been used in some countries as a fish poison. The dark green foliage and the colorful hoplike fruits make the plant worthy of consideration in landscape plantings.

\section{Cliffbush, Jamesia americana}

Torr. and Gray, is a deciduous shrub that grows to a height of 6 feet $(1.8$ $\mathrm{m})$. Cliffbush grows in moist canyons and along streams at elevations of 7,500 to 9,000 feet $(2,287$ to 2,745 $\mathrm{m}$ ) in the mountains from Wyoming to New Mexico and in southeastern Arizona west to California. It is not palatable to livestock or big game. It is used as an ornamental.

Common juniper, Juniperus communis L., or dwarf juniper, is a highly variable evergreen shrub that may be a tree in some areas. Common juniper is widespread in the

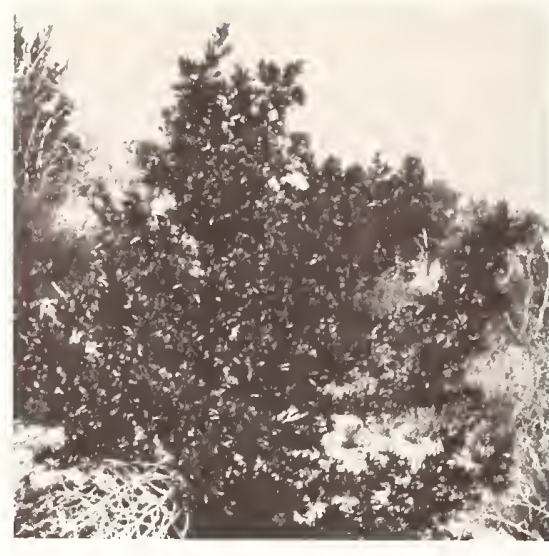

Figure 34. Hopseedbush, native to the Southwest, has attractive dark foliage.

mountains of the East and the West and from Alaska to New Mexico and Arizona. It shows promise for use in soil stabilization plantings. Lowgrowing forms are commonly used in landscaping.

\section{Shrubby cinquefoil, Potentilla} fruticosa $\mathrm{L}$., is a low, manybranched semievergreen shrub that grows from 1 to 4 feet ( 0.3 to 1.2 $\mathrm{m})$ tall. It has attractive yellow flowers and blooms throughout most of the summer. Many horticultural forms are available. Shrubby cinquefoil grows in the northern regions and south in the mountains to Arizona, Nevada, California, and New Mexico. It is in wet meadows in the Dakotas and Montana. Forage value is limited for livestock and big game. Shrubby cinquefoil is valuable for landscaping and for soil stabilization plantings on adapted sites.

\section{Golden currant, Ribes aureum} Pursh, is an attractive deciduous shrub that is 3 to 8 feet ( 0.9 to 2.4 m) tall. It grows from the Black Hills of South Dakota to Washington and south to New Mexico, Arizona, and California. Golden currant is often cultivated as an ornamental. It has been established by direct seeding and with seedlings. It is prized by big game for browse. The fruit are choice foods of many species of birds. Golden currant shows promise for use on moist sites.
Willows, Salix spp. L., are generally fast-growing, easily established plants on adapted sites. They grow on a wide range of moist wet soils. Most produce root shoots and are good soil binders. Willows provide food and cover for big game, upland game birds, and other wildlife. Most species are browsed by livestock. They are valuable for soil stabilization plantings on moist sites. It is important to select adapted ecotypes of adapted species. Willows are available for most areas.

Silver buffaloberry, Shepherdia argentea (Pursh) Nutt., is an attractive, grey-green, large shrub that produces an abundance of edible fruit. It grows from Kansas, New Mexico, Nevada, and Utah north to Saskatchewan and Alberta. Silver buffaloberry is most common on sandy soils but also grows on moist soils. It produces excellent wildlife food and cover. It is used as an ornamental plant and in windbreak plantings. It has considerable promise for use on mined lands in the Northern Great Plains plant growth region, and several assemblies are being evaluated. Common materials are available.

Common snowberry, Symphoricarpos albus (L.) Blake, is a thicketforming shrub that grows to a height of 3 feet $(0.9 \mathrm{~m})$. It is on dry rocky soils, calcareous barrens, and gravelly banks from New Mexico northward through the Rocky Mountains to Canada. There are many species of snowberries throughout the West.

Western snowberry, $S$. occidentalis Hook., is the most common species in the Northern and Central Great Plains plant growth regions from Oklahoma and New Mexico northward. Some species of Symphoricarpos are important locally as sources of livestock browse. They are browsed by big game and the seeds are eaten by many species of birds. Planting materials of some species are available in limited quantities. 


\section{Introduced trees and shrubs}

Several species of introduced trees and shrubs are important as conservation plantings of disturbed areas in the arid and semiarid areas of the West.

\section{Introduced tree for arid sites}

Tree tobacco, licotiana glauca Graham, is a smalı fast-growing tree introduced from S.uth America for landscaping. It grows to 20 feet $(6 \mathrm{~m})$. It has large thick evergreen leaves, and the stems and trunk are green. Seed production is excellent. The tubular pale yellow flowers bloom throughout the year if moisture is available. They are about 1 inch $(2.5 \mathrm{~cm})$ long and are attractive to hummingbirds. Tree tobacco has become naturalized in the Southwest from Texas to southern California at elevations below 3,000 feet $(915 \mathrm{~m})$. Animals usually avoid these plants, but cases of poisoning in cattle, horses, and sheep have been reported. Tree tobacco has value for low-maintenance landscaping, critical area stabilization, and reclamation. Though it furnishes only limited soil protection, this species is an important pioneer on barren areas. Several plantings with containerized plants have been established on mine tailings in southern Arizona. Containerized plants are available commercially.

Chilean mesquite, Prosopis chilensis (Mol.) Stuntz, is a small, fastgrowing tree introduced from Chile, South America. Its growth habit is similar to that of honey mesquite, $P$. juliflora (Sw.) DC., except that it is spineless and not as large. Chilean mesquite is an excellent forage plant, and the seeds are eaten by several species of birds. Chilean mesquite has been used as an ornamental plant in the Southwest at low elevations. It has value for low-maintenance landscaping, critical area stabilization, and reclamation. Several plantings have been made in southern Arizona on mine tailings where containerized plants and trickle irrigation were used. It has not been tested for establishment by direct seeding.

Athel tamarisk, Tamarix aphylla (L.) Karst., is a large, fast-growing evergreen tree introduced from Africa. It produces trunks 2 feet $(60 \mathrm{~cm})$ in diameter and may be 50 feet $(15.3 \mathrm{~m})$ tall. Athel tamarisk tolerates highly saline-alkali soils. During July and August the trees have a silvery appearance when high transpiration causes salt accumulation on the leaves and floral parts. It is frost tender, and the growth range is restricted to sea level to about 2,000 feet $(619 \mathrm{~m})$ in the Southwestern Desert, Southern Plateaus, and California Valleys plant growth regions. Athel tamarisk has been widely used in shelterbelts and windbreaks and for landscaping and planting on disturbed areas. It is normally reproduced by cuttings and is available as containerized stock.

\section{Introduced trees and shrubs for semiarid sites}

Oldman or bluegreen saltbush, Atriplex numularia Lindl., is a perennial erect shrub introduced from Australia. The plant is woody and grows to 9 feet $(2.7 \mathrm{~m})$. It is gray and scurfy and has large bluegreen leaves. This saltbush is adapted along the coast of southern California and the upper and lower Sonora Desert where there is a minimum mean annual precipitation of 7 inches $(18 \mathrm{~cm})$. The plant makes most of its growth early in spring and late in fall. It flowers during winter, and seed are borne between two bracts, or wings, similar to fourwing saltbush. Its performance on copper mines in Arizona is being determined.

Silver saltbush, Atriplex rhagodioides F. Muell., is a perennial shrub introduced from Australia. It develops an excellent ground cover as tall as 3 feet $(0.9 \mathrm{~m})$. It tolerates drought and is semisuffrutescent, monecious, and silvery green. Leaves are medium size and evergreen, and the young stem growth is purple. Silver saltbush is being field tested on mine tailings throughout southern Arizona. It appears to be adapted to the upper Sonora desert and the coastal area in southern California.

Australian saltbush, Atriplex semibaccata $\mathrm{R}$. Br., is a semiherbaceous species native to Australia. It was introduced many years ago and has become naturalized in southern California, Arizona, and New Mexico. It is a low-growing, spreading, semiprostrate plant. Australian saltbush tolerates drought and salt, is fast growing, and is a good reseeder. It persists and provides good cover with a mean annual precipitation of about 10 inches $(25 \mathrm{~cm})$ or in areas with less precipitation where there is run-in moisture. Supplemental irrigation is often necessary to establish stands or to maintain established stands in areas of lower precipitation. Hardiness limits have not been specifically determined, but in the Southwest Australian saltbush grows at elevations as high as 3,500 feet $(1,068$ $\mathrm{m})$. The plants are permanently damaged by temperatures of $10^{\circ} \mathrm{F}$ $\left(-12^{\circ} \mathrm{C}\right)$.

'Corto' Australian saltbush was released for use as ground cover on roadsides, mine spoils, and other disturbed areas. It is well adapted for landscaping but cannot withstand trampling. Forage values have not been determined, but cured plants are stiff and unpalatable to livestock. 'Corto' Australian saltbush is adapted to the Southwestern Desert and California Valleys and Foothills plant growth regions and lower elevations of the Southern Plateaus plant growth region. Seeds germinate best in the cooler seasons and should be planted early in fall.

Siberian peashrub, Caragana arborescens Lam., more often referred to as caragana, is an up- 


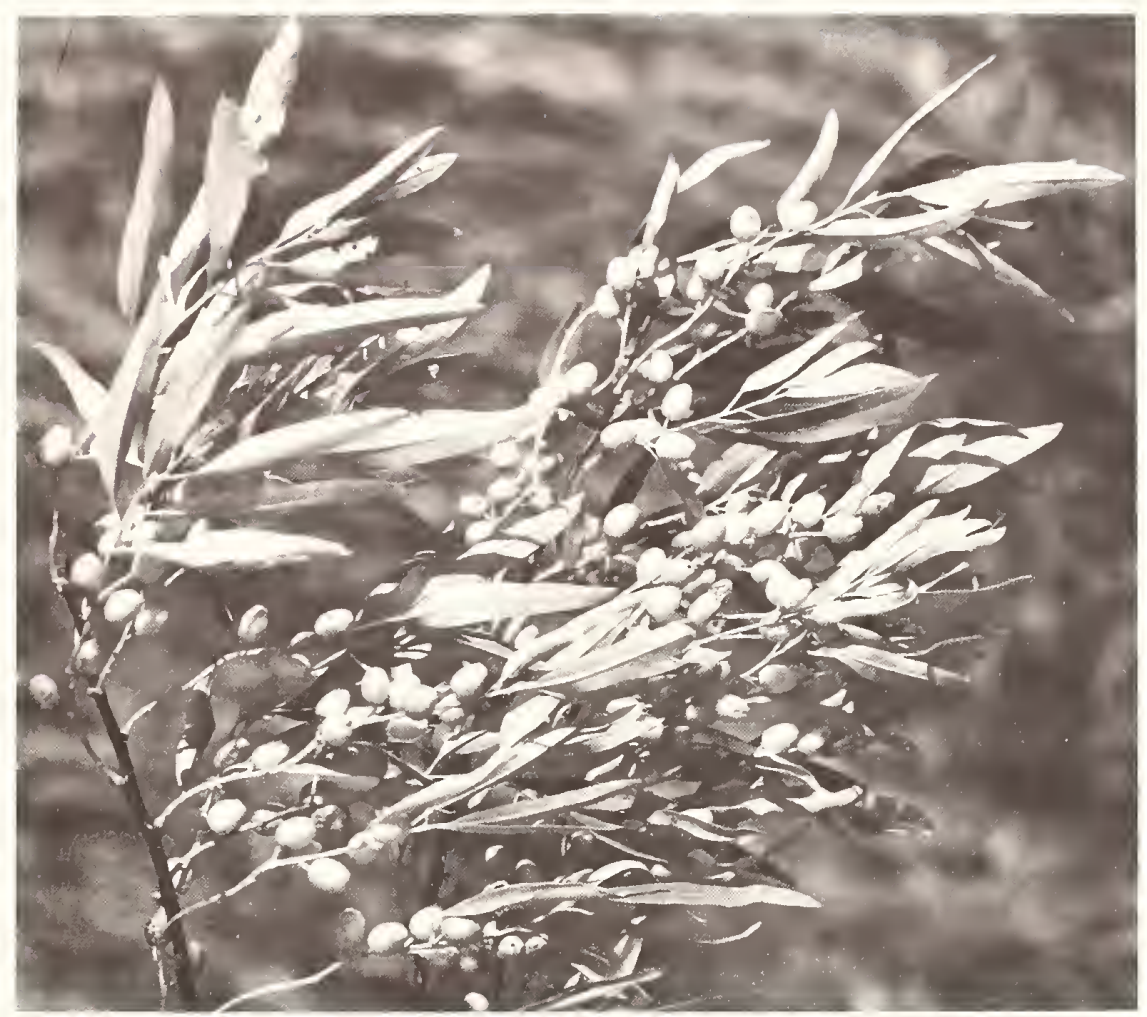

Figure 35. Russian-olive is easily established and grows well on reclaimed mined land.

right, branching shrub or small tree about 12 feet $(3.7 \mathrm{~m})$ tall but may grow as tall as 20 feet $(6 \mathrm{~m})$. It is a native of Siberia and Manchuria and is used extensively in the Northern Great Plains plant growth region. In the Central Great Plains plant growth region it is generally outperformed by other species. Siberian peashrub grows well and is widely used in the northern part of the intermountain region. It does not tolerate wet soils. Siberian peashrub tolerates alkali and drought and is a winter-hardy, long-lived species. It provides nesting sites for a number of birds. The seeds may be eaten by a few birds. It provides little browse for game. Common planting stock is available in quantity. Adapted materials should be used.

Russian-olive, Elaeagnus angustifolia L., is a winter-hardy, droughtresistant, large shrub or small tree (fig. 35). It is native to southern Europe, western Asia, and the western Himalayas. Russian-olive is best adapted to the Northern and Central Great Plains plant growth regions and to the intermountain region. It performs well in the foothills of the Rocky Mountains up to 8,000 feet $(2,440 \mathrm{~m})$ in New Mexico. On favorable sites Russian-olive grows to 25 feet $(7.6 \mathrm{~m})$ or more. It has attractive silvery-green leaves and produces abundant fruit palatgrows rapidly. Russian-olive has been widely used in single- and multiple-row windbreaks, but it does not tolerate shade. It tolerates alkali and performs well in a wide range of soil and moisture conditions. Russian-olive often invades saline flats that have a high water table and has become a weed on some sites. There is considerable variation in form, fruit color, size, and adaptability of Russian-olive. Planting materials are available in quantity. Cultivars need to be developed to ensure more consistent performance. able to many species of birds. If
'King-Red' Russian-olive, a recently released cultivar for conservation planting, appears to be adapted to a large area. It has a large-fruited type and has branches low to the ground. It has performed well from Los Lunas, N. Mex., to Bridger, Mont.

Eucalyptus, Eucalyptus spp. L'Her., are fast-growing trees introduced from Australia. There are several hundred named cultivars of many species. Eucalyptus species tolerate drought very well but usually require some irrigation for establishment and maintenance. The elevation range is restricted to below 1,200 feet $(366 \mathrm{~m})$ in the Southwestern Desert and California Valleys plant growth regions. The trees are injured in winter above this elevation. Eucalyptus trees are not grazed. They are poisonous to most animals if eaten in quantity. Tests on mine tailings in southern Arizona have been successful where irrigation was used to establish cuttings.

Tatarian honeysuckle, Lonicera tatarica L., is a medium to tall shrub native to Siberia. It is hardy in winter and tolerates drought. On favorable sites it may exceed a height of 12 feet $(3.7 \mathrm{~m})$. Tatarian honeysuckle is widely used in the Northern Great Plains plant growth region in windbreak plantings. It is also used in the northern intermountain area and the northern part of the Central Great Plains plant growth region. It is best adapted to well-drained soils. Tatarian honeysuckle has attractive pink to red flowers in May. It furnishes food and cover for birds. Numerous horticultural cultivars are available for landscaping. Planting materials for windbreaks are available in quantity for use in the area of adaptation.

Matrimonyvine, Lycium halimifolium Mill., is a vine or a small to large shrub as tall as 9 feet $(2.7 \mathrm{~m})$. It was introduced from Europe and is naturalized in parts of the West. 
Matrimonyvine tolerates drought and has persisted for years on abandoned farmsteads in the dryland wheat areas of the northern intermountain region. It has also been used in the Northern and Central Great Plains plant growth regions. Matrimonyvine has value for wildlife plantings and soil stabilization.

Afghanistan pine, Pinus brutia Ten., is a cultivated nut pine from the warm area of Afghanistan and is adapted to hot, arid conditions. It is a fast-growing tree with good form. Afghanistan pine has potential for use in landscaping plantings and windbreaks. There are conflicting reports on its tolerance to cold, but it has been grown successfully at Las Cruces, N. Mex., at an elevation of 3,900 feet $(1,190 \mathrm{~m})$ and at Sedona, Ariz., at 4,300 feet $(1,312$ $\mathrm{m})$. Planting materials are available in limited quantities.

\section{Introduced trees for mesic sites}

Ailanthus, Ailanthus altissima (Mill.) Swingle, more commonly known as tree-of-heaven, is a native of China that grows to a height of 100 feet $(30 \mathrm{~m})$. Ailanthus tolerates poor soils and smoky, gas-filled air near factories. Ailanthus grows best on well-drained moist soils but often escapes cultivation and grows in waste places. It is susceptible to storm damage. It is common throughout the East and in the Great Plains north to Kansas and Colorado. It is also used in the northern intermountain area and in parts of the Southwest. Cultivars are available for landscaping.

Austrian pine, Pinus nigra Arnold, and Scotch pine, Pinus sylvestris L., are important large pines introduced from Europe. In general, Austrian pine grows well as far north as South Dakota in the
Great Plains and Scotch pine is superior north of this area. Both species are highly variable, with considerable variation in their tolerance to drought and cold. Both grow well on sandy soils and on poor soils, and both are resistant to smoke.

They are widely used for windbreaks and landscaping. Care must be used in selecting materials adapted to the area and the planned use.

Common jujube, Zizyphus jujube Mill., is an attractive small tree, generally not more than 30 feet (9.2 $\mathrm{m})$ tall, native to Africa and Asia. It is widely used in the South from Florida to California as an ornamental plant and in windbreaks. It grows well as far north as southwestern Kansas in the Great Plains. The fruit may grow as large as an egg and are edible. Common jujube grows well on a wide range of moist soils except where the soil is clay or is very wet. 
Common and scientific names of plants ${ }^{1}$

\section{Common name}

acacia

blackbrush

catclaw

mescat

whitethorn

ailanthus

alder, thinleaf

alfalfa

alfileria

apacheplume

ash

\section{Arizona}

desert

green

velvet

aspen, quaking

astragalus

baccharis, broom

balsamroot, arrowleaf

barrelcactus southwest

bearberry

beargrass

bermudagrass

bitterbrush, antelope

blackbrush

bladderpod

bluegrass

big

Canada

Canby

Nevada

plains

Sandberg

upland

bluestem

big

cane

caucasian

little

sand

silver

yellow

bois-d'-arc
Scientific name

Page

Acacia Mill.

$A$. rigidula Benth.

A. greggii A. Gray .................... 53

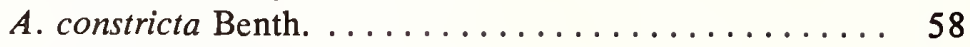

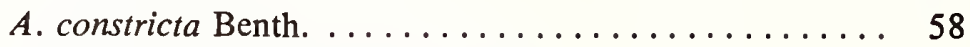

Ailanthus altissima (Mill.) Swingle ........... 67

Alnus tenuifolia Nutt.

Medicago sativa L. ................... 52

Erodium cicutarium (L.) L'Her. .............. 52

Fallugia paradoxa (D. Don) Endl. ............ 62

Fraxinus L.

F. velutina Torr. .................... 54

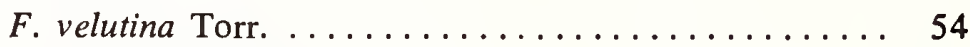

$F$. pennsylvanica Marsh ............... 56

F. velutina Torr. .................... 54

Populus tremuloides Michx.

Astragalus L.

Baccharis sarathroides Gray ................. 59

Balsamorhiza sagittata (Pursh) Nutt.

Echinocactus Link \& Otto

E. wislizeni Engelm.

Arctostaphylos Adans.

Nolina Michx.

Cynodon dactylon (L.) Pers. .................. 43

Purshia tridentata (Pursh) DC ............. 62

Coleogyne ramosissima Torr.

Isomeris arborea Nutt. . . . . . . . . . . . . . . 62

Poa, L.

P. ampla Merr. ..................... 38

P. compressa $\mathrm{L}$.

P. canbyi (Scribn.) Piper .................... 38

$P$. nevadensis Vasey

$P$. arida Vasey

P. secunda Presl.

P. glaucantha Gaudin ... . . . . . . . . . . . . . . . 44

Andropogon L.

A. gerardi Vitman ................... 36

A. barbinodis Lag. .................... 32

(Bothriochloa barbinodis (Lag.) Herter)

A. caucasicus Trin. ..................... 42

(Bothriochloa caucasica (Trin.) Hubb.)

A. scoparius Michx. .................... 34

(Schizachyrium scoparium (Michx.) Nash)

A. hallii Hack. ......................... 46

A. saccharaoides Swartz

A. ischaemum L. ...................... 42

(Bothriochloa ischaemum (L.) Keng)

Maclura pomifera (Raf.) Schneid.

See footnote at end of list. 
Common name

boxelder

boxleaf, myrtle bristlegrass, plains

brittlebush, white brome

'Blando'

California

meadow

mountain

smooth

red

'Regar'

buckbrush

buckthorn, California

buckwheat

California

sulfur

buffaloberry

roundleaf

silver

buffalograss

buffelgrass

bulrush

California

Olney

bundleflower, Illinois

burrograss

bursage

triangle

white

bushsunflower, annual

butterflybush

cactus, pricklypear

California-laurel

canarygrass, reed

caragana

cassia, coves or desert

catclaw

cattails

ceanothus

buckbrush

desert

Fendler

Martin

snowbrush

chamise

cherry, bitter

chess, soft

chokecherry
Acer negundo L.

Pachystima myrsinites (Pursh) Raf.

Setaria macrostachya H.B.K. ............... 32

Encelia farinosa A. Gray .................. 59

Bromus L.

B. mollis L. ....................... 42

B. carinatus Hook. \& Arn. .................. 42

B. biebersteinii Roem. \& Schult ............... 43

B. marginatus Nees ................... 39

B. inermis Leyss. . . . . . . . . . . . . . . . 44

B. rubens L. ...................... 45

B. biebersteinii Roem. \& Schult

Ceanothus L. ......................... 61

Rhamnus californica Eschsch.

Eriogonum Michx.

E. fasciculatum Benth. ............... 59

E. umbellatum Torr. ................... 62

Shepherdia Nutt.

$S$. rotundifolia Parry

S. argentea (Pursh) Nutt .................. 64

Buchloe dactyloides (Nutt.) Engelm. ............ 35

Cenchrus ciliaris L. ................... 42

Scirpus L.

S. californicus (C. A. Mey.) Steud.

S. olneyi Gray

Desmanthus illinoensis (Michx.) MacMill. ........... 49

Scleropogon brevifolius Phil.

Franseria Cav.



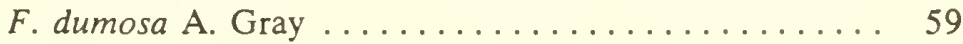

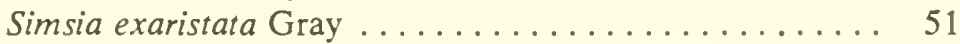

Buddleia scorioides H.B.K. . . . . . . . . . . ... 63

Opuntia Mill.

Umbellularia californica (Hook. \& Arn.) Nutt.

Phalaris arundinacea L................... 39

Caragana arborescens Lam. . . . . . . . . . . . . . . . 65

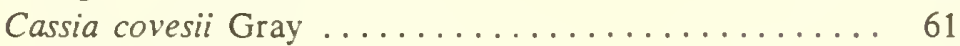

A cacia greggii A. Gray ................... 53

Typha L.

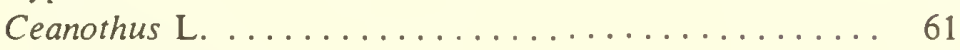



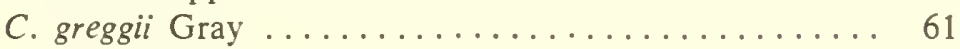

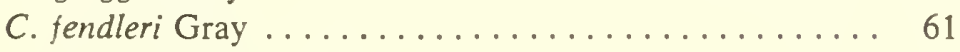

C. martinii M. E. Jones .................. 61

C. velutinus Dougl. .................. 63

Andenostoma fasciculatum H. \& A.

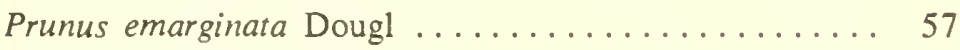

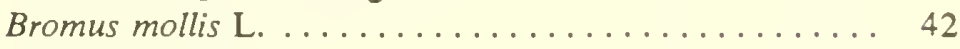

Prunus virginiana L. ................. 57

See footnote at end of list. 
Common name

cholla

cinquefoil, shrubby

cliffbush

cliffrose

clover

crimson

red

rose

strawberry

subterranean

white

condalia

cottontop, Arizona

cottonwood, western

creosotebush

crinkleawn

crownvetch

curlymesquite

currant, golden

cypress, Arizona

dalea

California

smokethorn

deergrass

desertbroom

desertwillow

dogwood, redosier

Douglas-fir

dropseed

giant

mesa

sand

spike

dunebroom

echinocereus, Engelmann

elder, red

ephedra

green

longleaf

eriogonum, sulfur

eucalyptus

false-mesquite

fernbush

fescue

Arizona

foxtail

hard

Idaho

rough

sheep

tall
Opuntia spp. Mill.

Potentilla fruticosa L. ................... 64

Jamesia americana Torr. \& Gray .............. 64

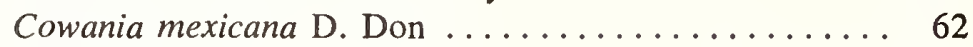

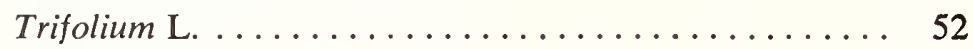

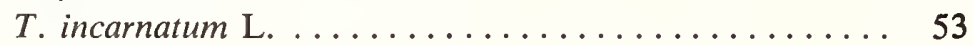



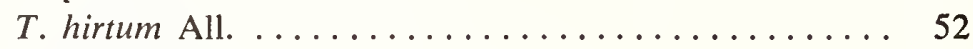



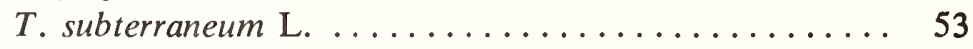

T. repens L....................... 53

Condalia Cav.

Tricachne californica (Benth.) Chase ........... 33

Populus sargentii Dode

Larrea divaricata Cav. .................. 60

Trachypogon secundus (Presl.) Scribn.

Coronilla varia L. ...................... 51

Hilaria belangeri (Steud.) Nash ............. 33

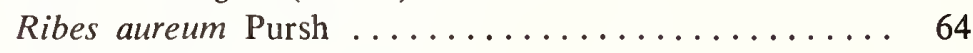

Cupressus arizonica Greene ............... 56

Dalea Willd.

D. californica S. Wats.

D. spinosa A. Gray

Muhlenbergia rigens (Benth.) Hitchc.

Baccharis sarathroides Gray ............................... 59

Chilopsis linearis (Cav.) Sweet ............... 54

Cornus stolonifera Michx. .................. 64

Pseudotsuga menziesii (Mirb.) Franco

Sporobolus R. Br.

S. giganteus Nash ...................... 48

S. flexuosus (Thurb.) Rydb. ................ 47

S. cryptandrus (Torr.) A. Gray .............. 47

S. contractus Hitchc. . . . . . . . . . . . . . . . . 47

Parryella filifolia Torr. \& Gray .............. 60

Echinocereus engelmannii (Parry) Ruempler

Alnus rubra Bong.

Ephedra L.

E. viridis Coville ..................... 59

E. trifurcata Torr.

Eriogonum umbellatum Torr. . . . . . . . . . . . . . . . 62

Eucalyptus L'Her .................... 66

Calliandra eriophylla Benth. ............. 60

Chamaebatiaria millefolium (Torr.) Maxim.

Festuca L.

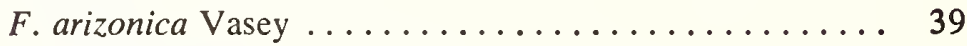

F. megalura Nutt. ................... 45

F. ovina duriuscula (L.) Koch ............. 45

F. idahoensis Elmer ................. 39

F. scabrella Torr.



F. arundinacea Schreb. .................. 44

See footnote at end of list. 
Common name

fescue-Continued

Thurber

fir

corkbark

grand

subalpine

foambush

forestiera, New Mexico

fountaingrass

foxtail

creeping meadow

meadow

gaillardia, slender

galleta

big

giantreed

globemallow, desert

goatnut

goldeneye, skeletonleaf

goldenweed, narrowleaf

goldpoppy

gooseberry, oakwoods

grama

black

blue

gyp

hairy

sideoats

greasewood

gromwell, wayside

guajillo

hackberry

common

netleaf

spiny

hairgrass, tufted

hardinggrass

hawthorn, fireberry

hemlock, mountain western

honeylocust

honeysuckle, tatarian

hopsage, spiny

hopseedbush

indiangrass

indigobush

janusia, slender

Jerusalem-thorn

jojoba

joshuatree

jujube

Abies Mill.

A. lasiocarpa arizonica (Merriam) Lemm.

$A$. grandis (Dougl.) Lindl.

A. lasiocarpa (Hook.) Nutt.

Holodiscus dumosus (Nutt.) Heller

Forestiera neomexicana A. Gray. ............... 62

Pennisetum setaceum (Forsk.) Chiov. ........... 46

Alopecurus L.

A. arundinaceus Poir. .................... 43

A. pratensis L. ...................... 43

Gaillardia pinnatifida Torr. .............. 50

Hilaria jamesii (Torr.) Benth. ............. 33

H. rigida (Thurb.) Benth. ................. 34

Arundo donax L. ................... 45

Sphaeralcea ambigua Gray

Simmondsia chinensis (Link) Schneid. ............ 60

Viguiera stenoloba Blake .................. 63

Haplopappus linearifolius DC

Eschscholzia Cham.

Ribes quercetorum Greene

Bouteloua Lag.

B. eriopoda (Torr.) Torr. ................. 33

B. gracilis (H.B.K.) Lag. .................. 35

$B$. breviseta Vasey

$B$. hirsuta Lag.

B. curtipendula (Michx.) Torr. ............... 34

Sarcobatus vermiculatus (Hook.) Torr.

Lithospermum ruderale Dougl.

Acacia berlandieri Benth.

Celtis L.

C. occidentalis L..................... 56

C. reticulata Torr. ...................... 54

C. pallida Torr. ...................... 61

Deschampsia caespitosa (L.) Beauv. ............. 39

Phalaris tuberosa stenoptera (Hack.) Hitchc. ......... 44

Crataegus chrysocarpa Ashe ................. 56

Tsuga mertensiana (Bong.) Carr.

$T$. heterophylla (Raf.) Sarg.

Gleditsia triacanthos L. ................... 56

Lonicera tatarica L........................ 66

Grayia spinosa (Hook.) Moq.

Dodonea viscosa Jacq. . . . . . . . . . . . . . . . . . . . . 64

Sorghastrum nutans (L.) Nash ................. 36

Amorpha fruticosa L. ................... 63

Janusia gracilis Gray

Parkinsonia aculeata L.................. 54

Simmondsia chinensis (Link) Schneid. ........... 60

Yucca brevifolia Engelm.

Zizyphus jujube Mill. .................. 67

See footnote at end of list. 
Common name

junegrass, prairie

juniper

common

creeping

dwarf

oneseed

Rocky Mountain

Utah

western

Kleingrass

kochia, green molly

koleagrass

leadplant

lechugilla

locust, New Mexico

lotebush

lovegrass

Atherstone

Boer

Lehmann

plains

sand

weeping

Wilman

lupine, silky

manzanita, greenleaf

maple

bigtooth

dwarf

matrimonyvine

melicgrass

menodora, rough

spiny

mentzelia

mescat

mesquite

Chilean

honey

milkvetch, cicer

molly, green

morningglory, bush

mountainmahogany

curlleaf

true

muhly

bush

mountain

spike

muttongrass

Natal redtop

needleandthread
Koeleria cristata (L.) Pers.

Juniperus L. . . . . . . . . . . . . . . . . 55

J. communis L....................... 64

J. horizontalis Moench. .................. 62

J. communis L. ...................... 64

J. monosperma (Engelm.) Sarg. . . . . . . . . . . . . . 55

J. scopulorum Sarg. ...................... 55

J. osteosperma (Torr.) Little ................. 55

J. occidentalis Hook. . . . . . . . . . . . . . . . . . . . 55

Panicum coloratum L.................. 43

Kochia americana S. Wats. ................ 62

Phalaris tuberosa hirtiglumis Batt. \& Trab. .......... 44

Amorpha canescens Pursh ................. 63

Agave lecheguilla Torr.

Robinia neomexicana A. Gray ............. 57

Condalia obovata Hook.

Eragrostis Beauv.

E. atherstonei Stapf. .................. 40

E. chloromelas Steud. ................. 40

E. lehmanniana Nees .................. 40

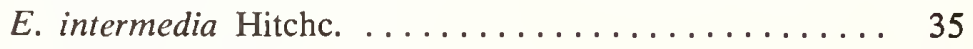

E. trichodes (Nutt.) Wood ................. 35

E. curvula (Schrad.) Nees .................. 40

E. superba Peyr. .................... 40

Lupinus sericeus Pursh

Arctostaphylos patula Greene

Acer L.

A. grandidentatum Nutt.

A. glabrum Torr.

Lycium halimifolium Mill. ................ 66

Melica L.

Menodora scabra Gray .................. 60

$M$. spinescens Gray

Mentzelia L.

Acacia constricta Benth. ................ 58

Prosopis $\mathbf{L}$.

P. chilensis (Mol.) Stuntz ................... 65

P. juliflora (Sw.) DC. ................. 65

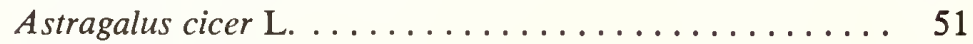

Kochia americana S. Wats. ............... 62

Ipomoea leptophylla Torr. ................ 50

Cercocarpus H.B.K.

C. ledifolius Nutt. ........................ 61

C. montanus Raf. ........................ 61

Muhlenbergia Schreb.

M. porteri Scribn. ................... 33

M. montana (Nutt.) Hitchc. .............. 33

M. wrightii Vasey .................. 33

Poa fendleriana (Steud.) Vasey

Rhynchelytrum roseum (Nees) Stapf. \& Hubb. ....... 43

Stipa comata Trin. \& Rupr. ............... 38

See footnote at end of list. 


\section{Common name}

needlegrass, green

ninebark

mallow

Pacific

oak

bur

California white

Gambel

sand live

shinnery

oat

oceanspray, bush

ocotillo

orchardgrass

Oregon-grape

osage-orange

paloverde

blue

foothills

littleleaf

Mexican

yellow

panicgrass

panicum, blue

pappusgrass

parryella

peashrub, Siberian

penstemon

Palmer

Rocky Mountain

perlagrass

phlox

pine

Afghanistan
Austrian
bristlecone
Chihuahua
Coulter
Digger
foxtail
limber
lodgepole
Mexican pinyon
pinyon
ponderosa
Scotch
singleleaf pinyon
western white
whitebark
dropseed
grass

Scientific name

Page

Stipa viridula Trin.

Physocarpus Maxim.

$P$. malvaceus (Greene) Kuntze

$P$. capitatus (Pursh) Kuntze

Quercus L........................... 56

Q. macrocarpa Michx. .................... 57

$Q$. lobata Nees

Q. gambelii Nutt. ................... 56

Q. virginiana maritima (Michx.) Sarg.

Q. havardii Rydb.

Avena sativa $\mathrm{L}$.

Holodiscus dumosus (Nutt.) Heller

Fouquieria splendens Engelm.

Dactylis glomerata L. ... . . . . . . . . . . . . . . . . 44

Berberis repens Lindl. .................... 63

Maclura pomifera (Raf.) Schneid. ............. 56

Cereidium floridum Benth. ............... 54

C. microphyllum (Torr.) Rose \& Johnst. . . . . . . . 54

C. microphyllum (Torr.) Rose \& Johnst. ......... 54

Parkinsonia aculeata L.................. 54

C. microphyllum (Torr.) Rose \& Johnst. .......... 54

Panicum antidotale Retz. ................. 43

Panicum antidotale Retz. ............... 43

Pappophorum Schreb.

Parryella filifolia Torr. \& Gray ............... 60

Caragana arborescens Lam. ................ 65

Penstemon Mitchell

P. palmeri A. Gray ................... 50

P. strictus Benth. .................... 50

Phalaris tuberosa hirtiglumis Batt. \& Trab. .......... 44

Phlox L.

Pinus L.............................. 55

P. brutia Ten. ...................... 67

P. nigra Arnold .................... 67

$P$. aristata Engelm.

P. leiophylla Schlect. \& Cham.

$P$. coulteri D. Don.

P. sabiniana Dougl.

$P$. balfouriana Grev. \& Balf.

$P$. flexilis James

P. contorta Dougl.

$P$. cembroides Zucc.

P. edulis Engelm. ......................... 55

$P$. ponderosa Laws. ...................... 55

P. sylvestris L........................ 67

P. monophylla Torr. \& Frem.

P. monticola Dougl.

$P$. albicaulis Engelm.

Blepharoneuron tricholepis (Torr.) Nash

Calamagrostis rubescens Buckl.

See footnote at end of list. 


\section{Common name}

pinyon

plum, American

poppy

California

gold

prairieclover

purple

white

pricklypear

Engelmann

quailbush

rabbitbrush

rubber

ratany, range

redbud, California

redcedar, eastern

redcedar, western

reed, common

retama

ricegrass, Indian

rockspirea, bush

rose

woods

Russian-olive

ryegrass

Swiss or Wimmera

sacaton, alkali

sage, pitcher

sagebrush

big

black

bud

fringed

low

sand

silver

sagewort, fringed

saguaro

sainfoin

saltbush

allscale

Australian

big

bluegreen

cattle

desert

fourwing

Nuttall

Oldman

Silver
Scientific name

Page

Pinus edulis Engelm. ..................... 55

Prunus americana Marsh. .................. 56

Eschscholzia california Cham. .............. 50

E. spp. Cham. ................... 50

Petalostemum Michx.

P. purpureum (Vent.) Rydb. ................ 51

P. candidum (Willd.) Michx. .............. 51

Opuntia Mill.

$O$. engelmannii Salm-Dyck

Atriplex lentiformis (Torr.) S. Wats. . . . . . . . . 58

Chrysothamnus Nutt.

C. nauseosus (Pall.) Britt. ................. 59

Krameria parvifolia Benth. .............. 62

Cercis occidentalis Torr.

Juniperus virginiana $\mathrm{L} . \ldots \ldots \ldots \ldots \ldots \ldots \ldots \ldots, 55$

Thuja plicata Donn

Phragmites communis Trin. .............. 46

Parkinsonia aculeata L. ................. 54

Oryzopsis hymenoides (Roem. \& Schult.) Ricker ...... 47

Holodiscus dumosus (Nutt.) Heller

Rosa L. ....................... 63

$R$. woodsii Lindl. ................... 63

Elaeagnus angustifolia L. .............. 66

Lolium $\mathbf{L}$.

L. rigidum Gaud. . . ................. 42

Sporobolus airoides (Torr.) Torr. .............. 49

Salvia pitcheri Torr. ................. 51

Artemisia L.

A. tridentata Nutt. .................... 60

A. arbuscula nova (A. Nels.) Cronq. ............ 60

A. spinescens Eat.

A. frigida Willd.

$A$. arbuscula Nutt.

A. filifolia Torr.

A. cana Pursh ........................ 60

Artemisia frigida Willd.

Cereus giganteus Engelm.

Onobrychis viciaefolia Scop. .............. 52

Atriplex L.

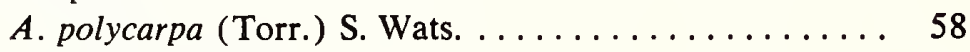



A. lentiformis (Torr.) S. Wats. ............ 58

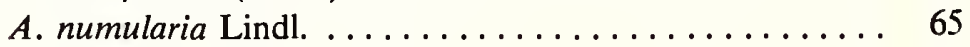

A. polycarpa (Torr.) S. Wats. ............ 58

A. polycarpa (Torr.) S. Wats. .............. 58

A. canescens (Pursh) Nutt. ............... 58

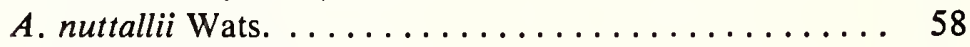

A. numularia Lindl. .................. 65

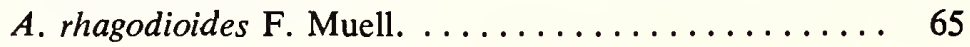

See footnote at end of list. 
Common name

saltgrass

desert or inland

sandbur, big

sandreed, prairie

sangre-de-cristo

sedge, threadleaf

seepweed, Torrey

serviceberry

Utah

shadscale

smilograss

snakeweed, broom

sticky

snowberry

common

western

snowbrush

soapberry, western

sorghum

sotol

spike-fescue

sprangletop, green

spruce

blue

Engelmann

white

squawbush

squawcarpet

squirreltail, bottlebrush

sudangrass

sumac

fragrant

littleleaf

skunkbush

summercypress, prostrate

sunflower

Maximilian

stiff

sweetclover

white

yellow

switchgrass

tamarisk, athel

tanglehead

tarbush

tesota

threeawn

poverty

tobacco, tree

tobosa

tree-of-heaven
Scientific name

Page

Distichlis Raf.

D. stricta (Torr.) Rydb.

Setaria macrostachya H.B.K.

Calamovilfa longifolia (Hook). Scribn. ............ 47

Jatropha spathulata (Hook.) Scribn.

Carex filifolia Nutt.

Suaeda torreyana S. Wats.

Amelanchier Med.

A. utahensis Koehne

Atriplex confertifolia (Torr. \& Frem.) S. Wats.

Oryzopsis miliacea (L.) Benth. \& Hook. ............ 44

Gutierrezia sarothrae (Pursh) Britt. \& Rusby

G. glutinosa (Schauer) Sch.-Bip.

Symphoricarpos Duham.

S. albus (L.) Blake ........................... 64

S. occidentalis Hook. . . . . . . . . . . . . . . . . . . . . 64

Ceanothus velutinus Dougl.

Sapindus drummondii Hook. \& Arn. . . . . . . . . . . . . . 57

Sorghum Moench

Dasylirion Zucc.

Hesperochloa (S. Wats.) Rydb.

Leptochloa dubia (H.B.K.) Nees ................ 32

Picea A. Dietr.

$P$. pungens Engelm.

$P$. engelmannii Parry

P. glauca (Moench) Voss

Rhus trilobata Nutt. .................... 62

Ceanothus prostratus Benth. ................ 63

Sitanion hystrix (Nutt.) J. G. Smith

Sorghum sudanese (Piper) Stapf.

Rhus L.

$R$. aromatica Ait.

R. microphylla Engelm. ................. 62

R. trilobata Nutt. .................... 62

Kochia prostrata (L.) Schrad. ............... 52

Helianthus L.

H. maximiliani Schrad. ................... 50

H. laetiflorus Pers. (H. Rigidus (Cass.) Desf.) ........ 50

Melilotus Mill.

M. alba Desr. ........................ 52

M. officinalis (L.) Desr.................... 52

Panicum virgatum L................... 36

Tamarix aphylla (L.) Karst. ................. 65

Heteropogon contortus (L.) Beauv.

Flourensia cernua DC

Olneya tesota A. Gray

A ristida L.

A. divaricata Humb. \& Bonpl.

Nicotiana glauca Graham ................... 65

Hilaria mutica (Buckl.) Benth. . . . . . . . . . . . . . 33

Ailanthus altissima (Mill.) Swingle ............... 67

See footnote at end of list. 
Common name

trefoil, birdsfoot trichloris, twoflower tridens, hairy tule, common twinberry vetch

American hairy woolypod virginsbower walnut Arizona black little Texas black wheatgrass beardless bluebunch crested Fairway intermediate pubescent Siberian slender standard crested streambank tall thickspike western

whitethorn wildrye basin beardless

blue mammoth Russian

willow winterfat

wolfberry

Anderson yerbasanta, California yucca

soaptree

blue or banana zexmenia, orange zinnia
Lotus corniculatus L. .................. 52

Trichloris crinita (Lag.) Parodi ............... 48

Tridens pilosus (Buckl.) Hitchc.

Scirpus acutus Muhl.

Menodora scabra Gray ..................... 60

\section{Vicia L.}

$V$. americana Muhl. ................... 51

V. villosa Roth ..................... 53

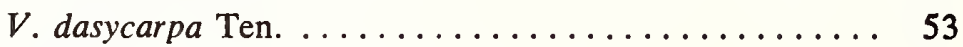

Clematis ligusticifolia Nutt. . . . . . . . . . . . . . 63

Juglans L.

J. major (Torr.) Heller ................. 55

J. microcarpa Berl. .................. 55

J. microcarpa Berl .................... 55

Agropyron Gaetn.

A. inerme (Scribn. \& Smith) Rydb. . . . . . . . . . 37

A. spicatum (Pursh) Scribn. \& Smith ........... 37

A. cristatum (L.) Gaertn. .................. 40

A. cristatum (L.) Gaertn. ................. 40

A. intermedium (Host) Beauv. ............ 41

A. tricophorum (Link) Richt. ............. 41

A. sibiricum (Wild.) Beauv. .............. 41

A. trachycaulum (Link) Malte ............. 38

A. desertorum (Fisch.) Schult. ............. 41

A. riparium Scribn. \& Smith ............... 45

A. elongatum (Host) Beauv. .............. 48

A. dasystachyum (Hook.) Scribn. .............. 45

A. smithii Rydb. .................... 37

Acacia constricta Benth. ................ 58

Elymus L.

E. cinereus Scribn. \& Merr. .................. 38

E. triticoides Buckl. ...................... 49

E. glaucus Buckl.

E. giganteus Vahl ..................... 47

E. junceus Fisch. ....................... 41

Salix L. ......................... 64

Eurotia lanata (Pursh) Moq. ................ 59

(Ceratoides lanata (L.) C. A. Mey.)

Lycium L.

L. andersonii A. Gray

Eriodycton californicum (H. \& A.) Torr.

Yucca L.

$Y$. elata Engelm. .................... 54

Y. baccata Torr.

Zexmenia hispida H.B.K. ................ 51

Zinnia L.

${ }^{1}$ Where there are no page numbers, plants are referred to under "vegetation" in plant growth regions. 


\section{Acknowledgments}

The author relied extensively on the reports of SCS plant materials specialists and plant materials center managers for plant performance data. The reviews and comments of the SCS staffs of the western states and the South, Midwest, and West Technical Service Centers contributed substantially.

The help of the Forest Service Surface Environment and Mining Program staff in Billings, Montana, was invaluable.

The mining industry and the Montana Department of State Lands suggested inclusion of specific items. Universities, agricultural experiment stations, and the USDA's Science and Education Administration have cooperated in much of the testing of materials.

$P$. N. Jensen, range conservationist, Lincoln, Nebr., and the following plant materials specialists made many helpful contributions, including species descriptions and adaptations of cultivars: J. C. Garrison, Phoenix, Ariz.; W. G. Hassell, Denver, Colo.; E. T. Jacobson, Bismarck, N. Dak.; R. G. Lohmiller, Bozeman, Mont.; and J. W. Walstrom, Salina, Kans. 


\section{References}

Aldon, E. F. 1978. Reclamation of coal-mined land in the Southwest. J. Soil Water Conserv. 33: 75-79.

American Society of Agronomy. 1978. F. W. Schaller and Paul Sutton (eds.). Reclamation of drastically disturbed lands. Madison, Wis. $742 \mathrm{p}$.

Austin, M. E. 1965. Land resource regions and major land resource areas of the United States, U.S. Dep. Agric. Handb. 296. Washington, D.C.

Benson, L., and R. A. Darrow. 1954. The trees and shrubs of the southwestern deserts. Univ. Ariz. Press, Tucson, Ariz.

Box, T. W. 1978. Significance and responsibility of rehabilitating drastically disturbed land. In F. W. Schaller and Paul Sutton (eds.). Reclamation of drastically disturbed lands. Am. Soc. Agron., Madison, Wis. p. 1-10.

Brown, R. W., R. S. Johnston, and D. A. Johnson. 1978. Rehabilitation of alpine tundra disturbances. J. Soil Water Conserv. 33: 154-160.

Cook, C. W., R. M. Hyde, and P. L. Sims. 1974. Guidelines for revegetation and stabilization of surface mined areas. Colo. St. Univ., Range Sci. Dep. Sci. Ser. No. 16. Fort Collins, Colo.

Cooper, H. W. 1957. Some plant materials and improved techniques used in soil and water conservation in the Great Plains. J. Soil Water Conserv. 12: 163168.

Cull, Chris. 1978. Western Energy Corp., Colstrip, Mont. Pers. Commun.

Davis, Grant. 1978. Oil shale. In F. W. Schaller and Paul Sutton (eds.). Reclamation of drastically disturbed lands. Am. Soc. Agron. Madison, Wis. p. 609-618.

Dayton, W. A. 1960. Notes on western range forbs: Equisetaceae through Fumariaceae. U.S. Dep. Agric. Handb. 161. Washington, D.C.

Dice, L. R. 1943. The biotic provinces of North America. Univ. Mich. Press, Ann Arbor, Mich.

Donovan, R. P., R. M. Felder, and H. H. Rogers. 1976. Vegetative stabilization of mineral waste heaps. U.S. Envirn. Prot. Ag., Tech. Ser. 600/2-76-087. Washington, D.C.

Farmer, E. E., and W. G. Blue. 1978. Reclamation of lands mined for phosphate. In F. W. Schaller and Paul Sutton (eds.). Reclamation of drastically disturbed lands. Am. Soc. Agron. Madison, Wis. p. 585-608.

Fowells, H. A. 1965. Silvics of forest trees of the United States. U.S. Dep. Agric. Handb. 271. Washington, D.C.

Francois, L. E. 1976. Salt tolerance of prostrate summercypress. Agron. J. 68: 455-456.
George, E. J. 1953. Tree and shrub species for the Northern Great Plains. U.S. Dep. Agric. Circ. 912. Washington, D.C.

Good, R. D. 1953. The geography of flowering plants. 2nd. ed. Longmans, Green and Co., N.Y.

Gould, F. W. 1975. Texas plants-a checklist and ecological summary. Texas Agric. Exp. Sta. Misc. Publ. 585 (Rev.). College Station, Tex.

Graham, E. H. 1941. Legumes for erosion control and wildlife. U.S. Dep. Agric. Misc. Publ. 412. Washington, D.C.

Hafenrichter, A. L., J. L. Schwendiman, H. L. Harris, R.S. MacLauchlan, and H. W. Miller. 1968. Grasses and legumes for soil conservation in the Pacific Northwest and Great Basin states. U.S. Dep. Agric. Handb. 339. Washington, D.C.

Hanson, A. A. 1972. Grass varieties in the United States. U.S. Dep. Agric. Handb. 170. Washington, D.C.

Harrington, H. D. 1954. Manual of the plants of Colorado. Sage Books, Denver, Colo.

Hermann, F. J. 1966. Notes of western range forbs: Cruciferae through Compositae. U.S. Dep. Agric. Handb. 293. Washington, D.C.

Hitchcock, A. S. 1950. Manual of the grasses of the United States. 2nd ed. rev. Agnes Chase (ed.) U.S. Dep. Agric. Misc. Publ. 200. Washington, D.C.

Johnson, E. W. 1966. Ornamental and windbreak trees for the southern Great Plains. U.S. Dep. Agric. ARS 34-77. Woodward, Okla.

Judd, B. I. 1962. Principal forage plants of southwestern ranges. U.S. Dep. Agric. Rocky Mountain Forest and Range Exp. Sta. Paper 69. Fort Collins, Colo.

Kearney, T. H., and R. H. Peebles. 1942. Flowering plants and ferns of Arizona. U.S. Dep. Agric. Misc. Publ. 423. Washington, D.C.

Kucheler, A. W. 1964. Potential natural vegetation of the conterminous United States. Am Geog., N.Y.

Leithead, H. L., L. L. Yarlett, and T. N. Shiflet. 1971. 100 native forage grasses in 11 southern states. U.S. Dep. Agric. Handb. 389, Washington, D.C.

Little, E. L. 1953. Checklist of native and naturalized trees of the United States, U. S. Dep. Agric. Handb. 41. Washington, D.C.

Martin, A. C., H. S. Zim, and A. L. Nelson, 1951. American wildlife and plants. McGraw-Hill Book Co., Inc., N.Y.

Mulford, F. L. 1938. Development of the plant growth region map. In Van Dersal, W. R. Native woody plants of the United States, their erosion-control and wildlife values. p. 16-27. 
Plummer, A. P., D. R. Christensen, and S. B. Monsen. 1968. Restoring big game range in Utah. Utah Div.

Fish and Game Publ. 68.3. Salt Lake City, Utah.

Power, J. F., R. E. Ries, and F. M. Sandoval. 1978.

Reclamation of coal mined land in the northern

Great Plains. J. Soil Water Conserv. 33: 69-74.

Rosendahl, C. O. 1955. Trees and shrubs of the upper Midwest. Univ. Minn. Press, St. Paul Minn.

Salac, S. S., P. N. Jensen, J. A. Dickerson, and R. W. Gray, Jr. 1978. Wildflowers for Nebraska landscapes. Univ. Nebr. Agric. Exp. Sta. Misc. Publ. 35. Lincoln, Nebr.

Schopmeyer, C. S. (Tech. Coord.). 1974. Seeds of woody plants in the United States. U.S. Dep. Agric. Handb. 450. Washington, D.C.

Sedgley, E. F. 1974. Revegetation potential of western rangelands in the oil shale region. In 2 nd Research and Applied Tech. Symp. on Mined-land Reclamation, Nat. Coal Assoc., Washington, D.C. p. 29-33.

Shiflet, T. N. 1973. Range sites and soils in the United States. In D. N. Hyder (ed.). Arid shrublands. Soc. Range Manage., Denver, Colo. p. 26-33.

Shishkin, B. K. 1936. Flora of the U.S.S.R. Translated into English 1970, and published by Israel Programs of Scientific Translations, Jerusalem. 6: 100-101.

Soil Conservation Society of America, Arizona Chapter. 1973. Landscaping with native Arizona plants. Univ. Ariz. Press, Tucson, Ariz.

Stroh, J. R., and A. A. Thornburg. 1969. Culture and mechanical seed harvest of fourwing saltbush grown under irrigation. J. Range Manage. 22: 60-62.

Stroh, J. R., J. L. McWilliams, and A. A. Thornburg. 1978. 'Garrison' creeping foxtail. U.S. Dep. Agric., SCS Tech. Pap. 156. Washington, D.C.

Thornburg, A. A., and S. H. Fuchs. 1978. Plant materials and requirements for growth in dry regions. In F. W. Schaller and Paul Sutton (eds.). Reclama- tion of drastically disturbed lands. Am. Soc. Agron., Madison, Wis. p. 411-324.

Thornthwaite, C. W. 1931. The climates of North America according to a new classification. Geog. Rev. 21: 633-655.

Thornthwaite, C. W. 1941. Climate and settlement in the Great Plains. Yearb. Agric., U.S. Dep. Agric., Washington, D.C. p. 177-187.

Tresler, R L. 1974. Strip mine reclamation in Wyoming. In 2nd Research and Applied Tech. Symp. on Mined-land Reclamation. Nat. Coal Assoc., Washington, D.C. p. 22-28.

U.S. Department of Agriculture, Agricultural Research Service. 1960. Plant hardiness zone map. U.S. Dep. Agric. Misc. Publ. 814. Washington, D.C.

U.S. Department of Agriculture, Forest Service. 1937. Range plant handbook. U.S. Dep. Agric., Washington, D.C.

U.S. Department of Agriculture, Soil Conservation Service. 1955 to 1978 . Plant materials annual technical reports, release notices, other SCS reports, and field office technical guides. Mimeographed materials.

U.S. Department of Agriculture, Soil Conservation Service. 1971. National list of scientific plant names. U.S. Dep. Agric., Washington, D.C.

U.S. Department of Commerce, Environmental Science Services Adm. 1968. Climatic atlas of the United States. Washington, D.C.

U.S. Department of Interior. 1967. Surface mining and our environment. U.S. Dep. Inter. Special Report. Washington, D.C.

Van Dersal, W. R. 1939. Native woody plants of the United States, their erosion control and wildlife valués. U.S. Dep. Agric. Misc. Publ. 303. Washington, D.C.

Vines, R. A. 1960. Trees, shrubs, and woody vines of the Southwest. Univ. Texas Press, Austin, Tex. 
Table 1.-- Species characteristics and adaptation to moisture, soil, and plant growth regions

[Specific adaptation and performance may vary by localized area and intended use. "Below optimum" indicates that the selection may be outperformed by other species or is not as competitive]

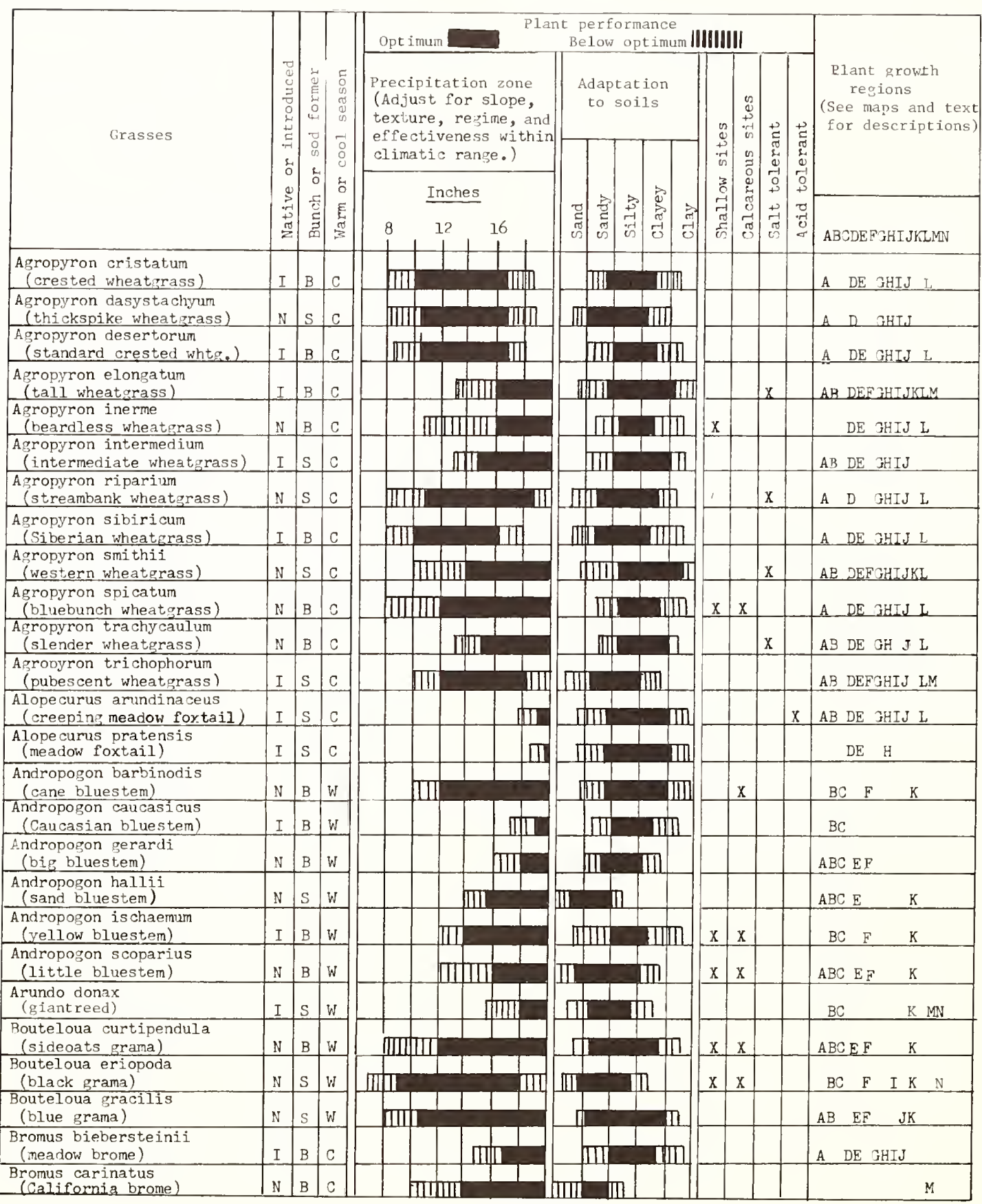














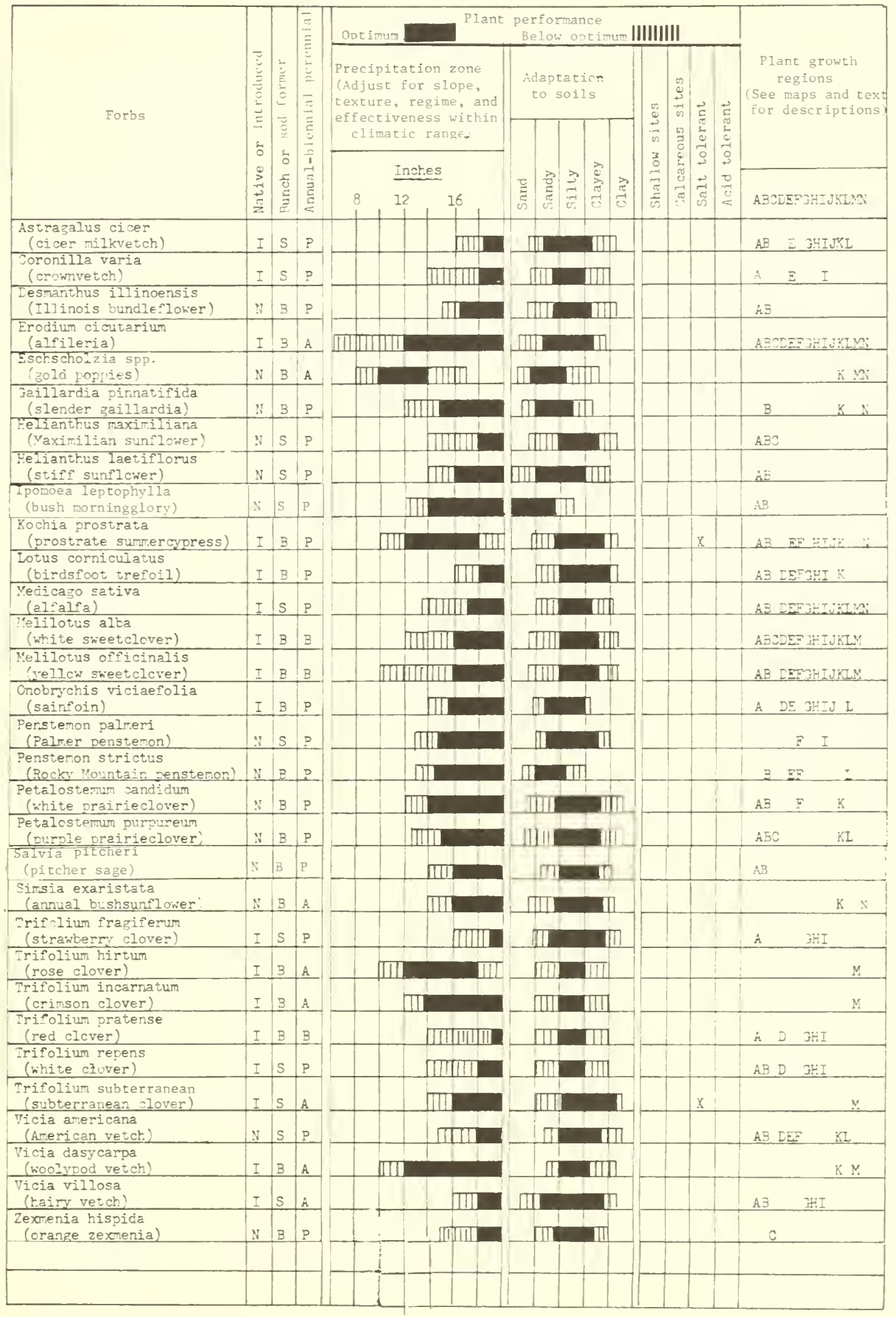


Table 1.--Species characteristics and adaptation to moisture, soil, and plant growth regions--continued

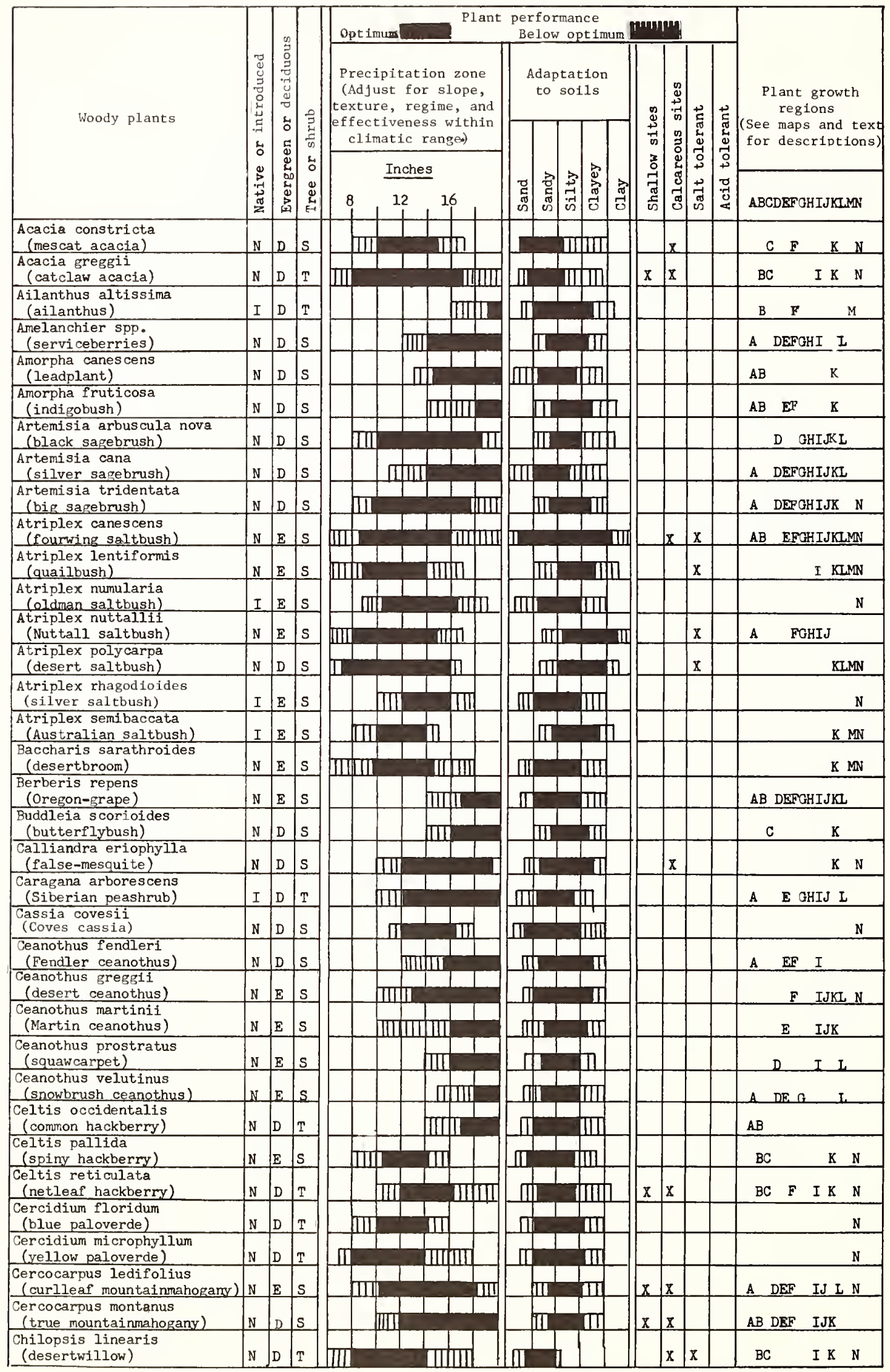







Table 1.-- Species characteristics and adaptation to moisture, soil, and plant growth regions--continued

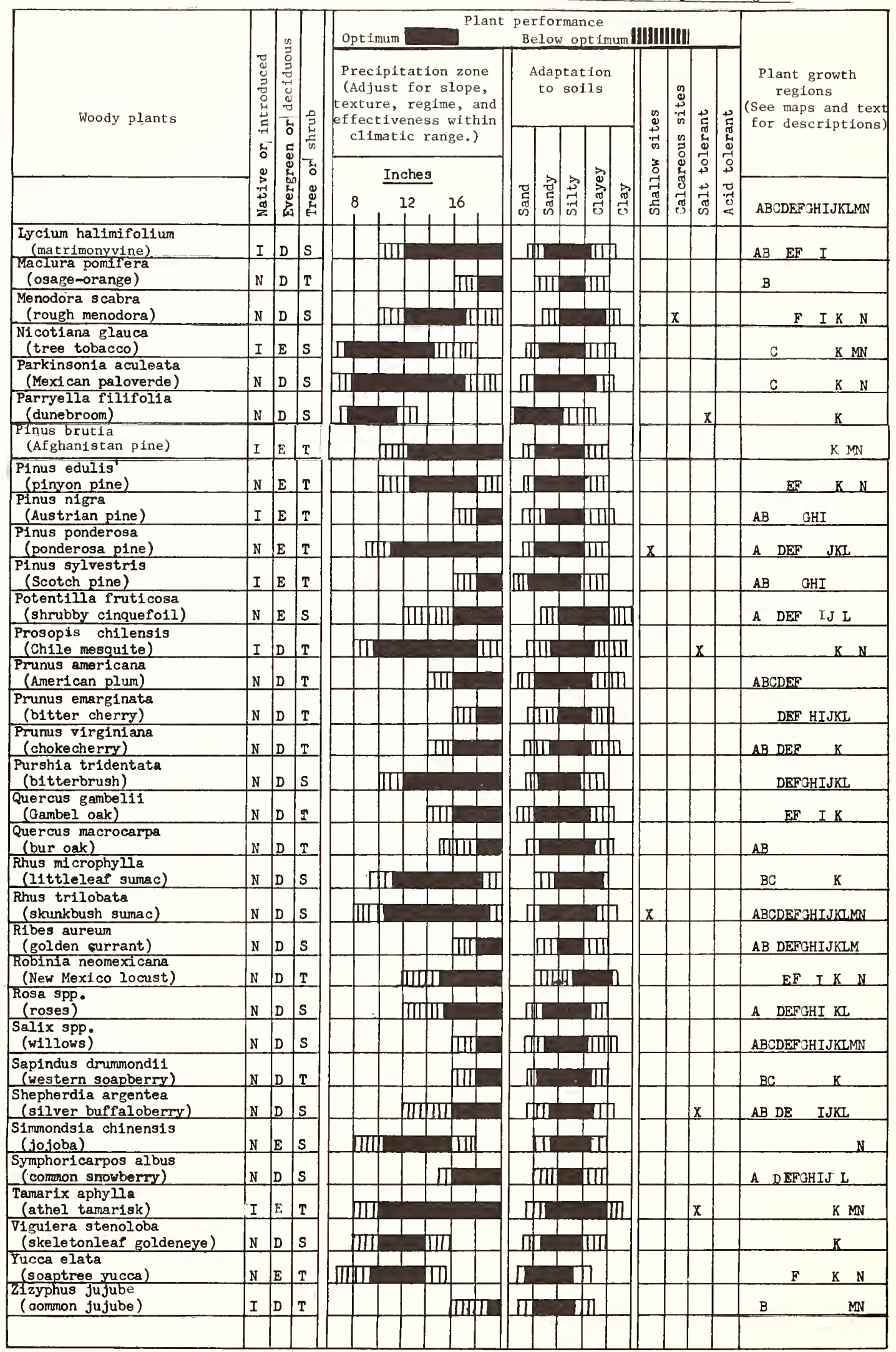




\begin{tabular}{|c|c|c|c|c|c|}
\hline Scientific name & $\begin{array}{l}\text { seed } \\
\text { per } \\
\text { pound } \\
\left(1000^{\prime} \mathrm{s}\right)\end{array}$ & $\begin{array}{l}\text { seed per } \\
\text { square foot } \\
\text { at } 1 \text { pound } \\
\text { per acre }\end{array}$ & Scientific name & $\begin{array}{l}\text { seea } \\
\text { per } \\
\text { pound } \\
\left(1000^{\prime} s\right)\end{array}$ & $\begin{array}{l}\text { seed p } \\
\text { square } \\
\text { at } 1 \text { por } \\
\text { per ac }\end{array}$ \\
\hline \multicolumn{6}{|l|}{ Grasses } \\
\hline  & 300 & 6.9 & $\frac{\text { Distichlis }}{\text { (inland saltgrass) }}$ & 520 & 12.0 \\
\hline$\frac{\text { Aoropyron }}{\text { (thickspike wheatgrass }}$ & 150 & 3.5 & $\frac{\text { Elymus }}{\text { (basin }} \frac{\text { cinereus }}{\text { wildrye) }}$ & 150 & 3.5 \\
\hline$\frac{\text { Agropyron }}{\text { (standard }} \frac{\text { desertorum }}{\left.\text { crested wht } t_{g}\right)}$ & 195 & 4.5 & $\frac{\text { Elymus }}{\text { (mammo } \frac{\text { giganteus }}{\text { th wildrye) }}}$ & 55 & 1.3 \\
\hline$\frac{\text { Agropyron elonga tum }}{\text { (tall whe }}$ & 75 & 1.7 & $\frac{\text { Elyms }}{\text { (Rिussian wildrye) }}$ & 170 & 3.9 \\
\hline$\frac{\text { Agropyron }}{\text { (beardless wheatge }}$ & 125 & 2.9 & $\frac{\text { Elymus }}{\text { (beardriticoides }}$ & 150 & 3.5 \\
\hline$\frac{\text { Acropyron }}{\text { (intermediate wheatigrass) }}$ & 80 & 1.8 & $\frac{\text { Eragrostis }}{\text { (Atherstone }} \frac{\text { atherstonei }}{\text { lovegrass) }}$ & 4,000 & 92.0 \\
\hline$\frac{\text { Agropyron }}{\text { (sireanbank wheatgrass) }}$ & 160 & 3.7 & $\frac{\text { Eragrostis }}{\text { (Boer lovegrass) }}$ & 2,800 & 64.4 \\
\hline$\frac{\text { Agropyron sibiricum }}{\text { (Siberian }}$ & 160 & 3.7 & $\frac{\text { Eragrostis }}{\text { (weeping }} \frac{\text { curvula }}{\text { ovegrass) }}$ & 1,500 & 34.5 \\
\hline$\frac{\text { A }}{\text { (westepyron }} \frac{\text { smithii }}{\text { wheatgrass) }}$ & 115 & 2.6 & $\frac{\text { Eragrostis }}{\text { (plains lovegrass) }}$ & 3,300 & 75.9 \\
\hline$\frac{\text { Agropyron snicatum }}{\text { (bluebunch wheatgrass) }}$ & 140 & 3.2 & $\frac{\text { Fragrostis }}{\text { (Lehmann lehmanniana }}$ & 6,500 & $1 / 9.0$ \\
\hline$\frac{\text { Agropyron }}{\text { (slender }} \frac{\text { trachycalilum }}{\text { wheatgrass) }}$ & 135 & 3.1 & $\frac{\text { Eragrost1s }}{\text { (Wilman lovegrass) }}$ & 1,100 & 25.3 \\
\hline$\frac{\text { Agropyron }}{\text { (pubescent wheatgrass) }}$ & 80 & 1.8 & $\frac{\text { Fragrostis }}{\text { (sand love }} \frac{\text { trass })}{\text { sades }}$ & 1,500 & 34.5 \\
\hline$\frac{\text { Alopecuris }}{\text { (creening } \frac{\text { rundinaceus }}{\text { meadow foxtail) }}}$ & 750 & 17.2 & $\frac{\text { Festuca }}{\text { (Arizonazonica }}$ & 410 & 9.4 \\
\hline$\frac{\text { Alopecurus }}{\text { (meadow foxtail) }}$ & 400 & 9.2 & $\frac{\text { Festuca }}{\text { (tall fescue) }}$ & 210 & 4.8 \\
\hline$\frac{\text { Andropogon }}{\text { (cane bluestem) }}$ & 750 & $17 . ?$ & $\frac{\text { Festuca }}{\text { (Idaho fescue) }}$ & 450 & 10.3 \\
\hline$\frac{\text { Andropogon }}{\text { (Caucasian }} \frac{\text { caucasicus }}{\text { bluestem) }}$ & 860 & 19.8 & $\frac{\text { Festuca megalura }}{\text { (foxtail fescue) }}$ & 800 & 18.4 \\
\hline$\frac{\text { Andropogon }}{\text { (big bluestem) }}$ & 130 & 3.0 & $\frac{\text { Festuca }}{\text { (sheep }} \frac{\text { ovina }}{\text { fescue) }}$ & 680 & 15.6 \\
\hline$\frac{\text { Andropogon hallii }}{\text { (sand bluestem) }}$ & 100 & 2.3 & $\frac{\text { Festuca }}{\text { (hard fescue) }}$ ovina duscula & 560 & 13.0 \\
\hline$\frac{\text { Andropogon }}{\text { (yellow bluestem) }}$ & 830 & 19.1 & $\frac{\text { Festuca }}{\text { (Thurber fescue) }}$ & 500 & 102.0 \\
\hline$\frac{\text { Andropogon }}{\text { (little bluestem) }}$ & 240 & 5.5 & $\frac{\text { Hilaria belangeri }}{\text { (curlynesquite) }}$ & 270 & 6.2 \\
\hline$\frac{\text { Bouteloua }}{\text { (sideoats } \frac{\text { curtipendula }}{\text { grama) }} \text { (spike) }}$ & $\begin{array}{l}140 \\
720\end{array}$ & $\begin{array}{r}3.2 \\
16.5\end{array}$ & $\frac{\text { Hilaria }}{(\text { galletamesii }}$ & 160 & 3.7 \\
\hline $\begin{array}{l}\text { (Avg. mixture) } \\
\text { Bouteloua eriopoda }\end{array}$ & $\begin{array}{r}250 \\
1,300\end{array}$ & $\begin{array}{r}5.8 \\
30.6\end{array}$ & $\frac{\text { Hilaria mutica }}{\text { (tohosa) }}$ & 200 & 4.6 \\
\hline $\begin{array}{l}\text { (black grama) } \\
\text { Bouteloua gracilis }\end{array}$ & 725 & 16.7 & $\frac{\text { Hilaria }}{\text { (big galleta) }}$ & 33 & 0.8 \\
\hline $\begin{array}{l}\text { (blue grama) } \\
\text { Bromus biebersteinii }\end{array}$ & 80 & 18 & Leptochloa dubia & 540 & 12.4 \\
\hline (meadow brome) & & 1.8 & $\begin{array}{l}\text { (green sprangletop) } \\
\text { Lolium rigidum }\end{array}$ & 185 & 4.3 \\
\hline$\frac{\text { Bromus }}{\text { (California brome) }}$ & 115 & 3.3 & $\begin{array}{l}\text { (Wimmera ryegrass) } \\
\text { Muhlenbergia montana }\end{array}$ & & \\
\hline Bromas inermis & Lio & 3.2 & $\frac{\text { Muhlenbergia montana }}{\text { (mountain muhly) }}$ & 1,500 & 34. \\
\hline $\begin{array}{l}\text { (smooth broine) } \\
\text { gromus maroinatus }\end{array}$ & 90 & 2.1 & $\frac{\text { Muhlenbergia porteri }}{\text { (bush muily) }}$ & 2,400 & 55.2 \\
\hline $\begin{array}{l}\text { (mountain brome) } \\
\text { Sromus mollis }\end{array}$ & 265 & 6.1 & $\frac{\text { Muhlenbergia wrightii }}{\text { (soike muk:Iy) }}$ & 1,600 & 37.6 \\
\hline $\begin{array}{l}\text { (soft chess) } \\
\text { Bromus rubens }\end{array}$ & 260 & 6.0 & $\frac{\text { Oryzopsis hymenoides }}{\text { (Indian }}$ & 160 & 3.7 \\
\hline $\begin{array}{l}\text { (red brome) } \\
\text { Buchloe dactyloides }\end{array}$ & 275 & 6.3 & $\frac{\text { Oryzopsis }}{\text { (smilograss) }}$ & 1,900 & 43.7 \\
\hline (buffalograss) & 40 & 0.9 & Panicuss antidotale & 650 & 24.9 \\
\hline$\frac{\text { Calamovilfa }}{\text { (prairie sandreed) }}$ & 275 & 6.3 & $\begin{array}{l}\text { (blue panicgrass) } \\
\text { Panicum coloratum }\end{array}$ & 490 & 11.3 \\
\hline $\begin{array}{ll}\text { Cenchrus ciliaris } & \text { (grain) } \\
\text { (buffelgrass) } & \text { (burs) }\end{array}$ & $\begin{array}{r}860 \\
225 \\
1,500\end{array}$ & $\begin{array}{r}19.8 \\
5.2 \\
34.5\end{array}$ & $\begin{array}{l}\text { (Kleingrass) } \\
\text { Panicum } \\
\text { (switchgrass) }\end{array}$ & 275 & 6.3 \\
\hline $\begin{array}{l}\text { (Bermudagrass) } \\
\text { Dactylis glomerata }\end{array}$ & 540 & 12.4 & $\frac{\text { Penaisetum }}{\text { (fountaingrass) }}$ & 275 & 6.3 \\
\hline
\end{tabular}




\begin{tabular}{|c|c|c|c|c|c|}
\hline Scientific name & $\begin{array}{l}\text { Seed } \\
\text { per } \\
\text { pound } \\
\left(1000^{\prime} \mathrm{s}\right)\end{array}$ & $\begin{array}{l}\text { Seed per } \\
\text { square foot } \\
\text { at } 1 \text { pound } \\
\text { per acre }\end{array}$ & Scientific name & $\begin{array}{l}\text { Seed } \\
\text { per } \\
\text { pound } \\
\left(1000^{\prime} \text { 's) }\right.\end{array}$ & $\begin{array}{l}\text { Seed per } \\
\text { square foot } \\
\text { at } 1 \text { pound } \\
\text { per acre }\end{array}$ \\
\hline
\end{tabular}

Grasses (cont.)

\begin{tabular}{|c|c|c|}
\hline$\frac{\text { Phalaris }}{\text { (reed canarygrass) }}$ & 540 & 7.8 \\
\hline$\frac{\text { Phalaris }}{\text { (perlagrass) }}$ & 267 & 6.1 \\
\hline$\frac{\text { Phalaris }}{\text { (Hardinggrass) }} \frac{\text { tuberosa }}{\text { stenoptera }}$ & 370 & 8.5 \\
\hline Poa (big bluegrass) & 885 & 20.3 \\
\hline Poa canbyi & 925 & 21.3 \\
\hline Poa glaucantha & 2,500 & 57.5 \\
\hline$\frac{\text { Setaria }}{\text { (plains }} \frac{\text { ma crostachya }}{\text { bristlegrass) }}$ & 290 & 6.7 \\
\hline$\frac{\text { Sorghastrum nutans }}{\text { (Indiangrass) }}$ & 175 & 4.0 \\
\hline$\frac{\text { Sporobolus }}{\text { (alkali sacaton) }}$ & 1,600 & 36.8 \\
\hline$\frac{\text { Sporobolus }}{\text { (spike dropseed) }}$ & 2,800 & 64.4 \\
\hline$\frac{\text { Sporobolus }}{\text { (sand dropseed) }}$ & 5,600 & 128.7 \\
\hline$\frac{\text { Sporobolus }}{\text { (mesa dropseed) }}$ & 3,300 & 75.9 \\
\hline$\frac{\text { Sporobolus giganteus }}{\text { (giant dropseed) }}$ & 1,400 & 32.2 \\
\hline Stipa comata & 115 & 2.6 \\
\hline $\begin{array}{l}\text { (needleand thread) } \\
\text { Stipa viridula } \\
\text { (green needlegrass) }\end{array}$ & 165 & 3.8 \\
\hline$\frac{\text { Trichachne }}{\text { (Arizona californica }}$ & 1,000 & 23.0 \\
\hline$\frac{\text { Trichloris }}{\text { (twoflower }} \frac{\text { crinita }}{\text { trichloris) }}$ & 1,400 & $36 \cdot 6$ \\
\hline
\end{tabular}

Forbs

\begin{tabular}{|c|c|c|}
\hline$\frac{\text { Astragalus }}{\text { (cicer milker }} \frac{\text { cich) }}{\text { kvetch }}$ & 135 & 3.1 \\
\hline$\frac{\text { Coronilla }}{\text { (crownvet } \frac{\text { varia }}{\text { ch) }}}$ & 120 & 2.8 \\
\hline$\frac{\text { Desmanthus }}{\text { (Illinois }} \frac{\text { illinoensis }}{\text { bundleflower) }}$ & 85 & 2.0 \\
\hline$\frac{\text { Eschscholzia }}{\text { (California poppy) }}$ & 300 & 6.9 \\
\hline$\frac{\text { Gaillardia pinnatifida }}{\text { (slender gaillardia) }}$ & 302 & 5.6 \\
\hline Helianthus maximiliani & 150 & 3.5 \\
\hline$\frac{\text { Helianthus }}{\text { (stiff sunflower) }}$ & 85 & 2.0 \\
\hline$\frac{\text { Kochia }}{\text { (prostrate summercypress) }}$ & 500 & 11.6 \\
\hline$\frac{\text { Lotus }}{\text { (birdsfoot trefoil) }}$ & 400 & 9.2 \\
\hline$\frac{\text { Medicago sativa }}{\text { (alfalfa) }}$ & 230 & 5.3 \\
\hline$\frac{\text { Melilotus alba }}{\text { (white sweetclover) }}$ & 260 & 6.0 \\
\hline$\frac{\text { Melilotus }}{\text { (yellow }}$ officinalis & 260 & 6.0 \\
\hline$\frac{\text { Onobrychis viciaefolia }}{\text { (sainfoin) }}$ & 20 & 0.5 \\
\hline$\frac{\text { Penstemon }}{\text { (Palmer }} \frac{\text { palmeri }}{\text { penstemon) }}$ & 600 & 13.8 \\
\hline$\frac{\text { Penstemon }}{\text { (Rocky Mountain penstemon) }}$ & 286 & 40.0 \\
\hline
\end{tabular}

\begin{tabular}{|c|c|c|}
\hline$\frac{\text { Petalos temum }}{\text { (white prairieclover) }}$ & 385 & 8.9 \\
\hline$\frac{\text { Petalostemum }}{\text { (purple prairieclover) }}$ & 300 & 6.9 \\
\hline$\frac{\text { Simsia }}{\text { (annual bushsunflata }}$ & 330 & 7.6 \\
\hline$\frac{\text { Trifolium }}{\text { (strawberry ragiferum }}$ & 300 & 6.9 \\
\hline$\frac{\text { Trifolium hirtum }}{\text { (rose clover) }}$ & 140 & 3.2 \\
\hline$\frac{\text { Trifolium }}{\text { (crimson }} \frac{\text { incarnatum }}{\text { clover) }}$ & 140 & 3.2 \\
\hline$\frac{\text { Trifolium pratense }}{\text { (red clover) }}$ & 275 & 6.3 \\
\hline$\frac{\text { Trifolium }}{\text { (white clopens }}$ & 700 & 16.1 \\
\hline$\frac{\text { Trifolium subterraneum }}{\text { (subterranean clover) }}$ & 65 & 1.5 \\
\hline$\frac{\text { Vicia americana }}{\text { (Amerícan vetch) }}$ & 41 & 0.9 \\
\hline$\frac{\text { Vicia }}{\text { (wool lasycarpa }} \frac{\text { ypod vetch) }}{\text { ypet }}$ & 11 & 0.3 \\
\hline$\frac{\text { Vicia }}{\text { (hairy villosa }}$ & 20 & 0.5 \\
\hline$\frac{\text { Zexmenia }}{\text { (orange }} \frac{\text { hispida }}{\text { zexmenia) }}$ & 250 & 5.8 \\
\hline
\end{tabular}

Seed data are furnished for only a few woody plants. These are for species which are most likely to be direct seeded. C.S. Schopmeyer (1974) presents data on the germination and propagation of many species of woody plants.

\begin{tabular}{|c|c|c|}
\hline$\frac{\text { Acacia }}{\text { (catclaw acacia) }}$ & 30 & 0.7 \\
\hline$\frac{\text { Amorpha }}{\text { (leadplant) }}$ & 125 & 2.9 \\
\hline$\frac{\text { Atriplex }}{\text { (fourwing saltbush) }}$ & 50 & 1.2 \\
\hline$\frac{\text { A'triplex }}{\text { (quailbush) }}$ & 500 & 11.6 \\
\hline$\frac{\text { Atriplex }}{\text { (Nuttall }} \frac{\text { nuttallii }}{\text { saltbush) }}$ & 110 & 2.5 \\
\hline$\frac{\text { Atriplex }}{\text { (Australian saltbush) }}$ & 240 & 5.5 \\
\hline
\end{tabular}

1/ To determine seed per kilogram multiply seed per pound by 2.205 . To determine seed per square meter at 1 kilogram per hectare, multiply seed per square foot at 1 pound per acre by 9.60 . 

